\title{
Arbeidsmarktmonitor Metalektro
}

Citation for published version (APA):

Kriechel, B., de Grip, A., \& Coenen, J. B. (2008). Arbeidsmarktmonitor Metalektro: Editie 2008. ROA. ROA Reports No. 002 https://doi.org/10.26481/umarep.2008002

Document status and date:

Published: 01/01/2008

DOI:

10.26481/umarep.2008002

Document Version:

Publisher's PDF, also known as Version of record

\section{Please check the document version of this publication:}

- A submitted manuscript is the version of the article upon submission and before peer-review. There can be important differences between the submitted version and the official published version of record.

People interested in the research are advised to contact the author for the final version of the publication, or visit the DOI to the publisher's website.

- The final author version and the galley proof are versions of the publication after peer review.

- The final published version features the final layout of the paper including the volume, issue and page numbers.

Link to publication

\footnotetext{
General rights rights.

- You may freely distribute the URL identifying the publication in the public portal. please follow below link for the End User Agreement:

www.umlib.nl/taverne-license

Take down policy

If you believe that this document breaches copyright please contact us at:

repository@maastrichtuniversity.nl

providing details and we will investigate your claim.
}

Copyright and moral rights for the publications made accessible in the public portal are retained by the authors and/or other copyright owners and it is a condition of accessing publications that users recognise and abide by the legal requirements associated with these

- Users may download and print one copy of any publication from the public portal for the purpose of private study or research.

- You may not further distribute the material or use it for any profit-making activity or commercial gain

If the publication is distributed under the terms of Article $25 \mathrm{fa}$ of the Dutch Copyright Act, indicated by the "Taverne" license above, 


\section{Arbeidsmarktmonitor Metalektro}

Editie 2008

Ben Kriechel

Andries de Grip

Johan Coenen

ROA-R-2008/2 


\section{Colofon}

(C) Researchcentrum voor Onderwijs en Arbeidsmarkt (ROA). Niets uit deze uitgave mag op enige manier worden verveelvoudigd zonder voorafgaande schriftelijke toestemming van de directeur van het ROA.

\section{Researchcentrum voor Onderwijs en Arbeidsmarkt}

Faculteit der Economische Wetenschappen en Bedrijfskunde

Universiteit Maastricht

\section{Vormgeving}

ROA secretariaat, Maastricht

\section{Verkoop}

Researchcentrum voor Onderwijs en Arbeidsmarkt email: secretary@roa.unimaas.nl website: www.roa.unimaas.nl

ISBN: 978-90-532I-464-0

juni 2008

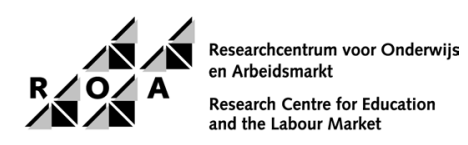




\section{Inhoud}

Voorwoord

Management Summary $\quad$ ix

1 Dynamiek en verandering in de Metalektro 1

1.1 Conjuncturele ontwikkelingen 1

1.2 Werkgelegenheidsontwikkelingen op de lange termijn 3

1.3 Technologische veranderingen 6

$\begin{array}{ll}1.4 \text { Organisatorische verandering en sociale innovatie } & 7\end{array}$

2 Arbeidsmarktontwikkelingen in $2007 \quad 9$

2.1 De personeelsinstroom in 2007

2.2 De personeelsuitstroom in $2007 \quad 12$

2.3 De werkgelegenheidsontwikkelingen in $2007 \quad 14$

2.4 Flexibel inlenen $\quad 15$

3 Het aantrekken van nieuw personeel 17

$\begin{array}{ll}3.1 \text { Verloop van personeel } & 17\end{array}$

3.2 Effectieve wervingskanalen $\quad 20$

3.3 Vacatures 26

3.4 Problemen bij de werving $\quad 32$

4 Competentieontwikkeling en HRM 35

4.1 Opleiden in de Metalektro 35

4.2 Scholing en competenties $\quad 39$

$\begin{array}{ll}4.3 \text { Communicatie } & 40\end{array}$

5 Loopbaanmanagement $\quad 43$

5.1 Competentietekorten bij schoolverlaters $\quad 43$

5.2 Vaktechnische en POFI+ vaardigheden 44

5.3 Loopbaanbeleid 45

6 Sociale innovatie 51

6.1 Sociale innovatie in de Metalektro 51

6.2 Brede inzetbaarheid 60 
7 Vergrijzing en het moderne HRM beleid

7.1 Uitstroom en vervangingsprobleem

7.2 Maatregelen voor oudere werknemers

8 De Metalektro in de toekomst

8.1 Verwachte ontwikkelingen op de arbeidsmarkt 2007-2012

8.2 Werven in de toekomst

8.3 Veranderingen in functies

8.4 Speerpunten voor toekomstig HRM

9 Agenda voor de toekomst

9.1 Ontwikkelingen en trends

83

9.2 Agenda voor de Toekomst

88 


\section{Voorwoord}

In 2002 is in opdracht van de Stichting $\mathrm{A}+\mathrm{O}$ een start gemaakt met de opzet van een Arbeidsmarktmonitor voor de Nederlandse Metalektro. Deze monitor geeft inzicht in de actuele ontwikkelingen op de arbeidsmarkt en de toekomstige ontwikkelingen op personeels- en arbeidsmarktgebied in de metalektrosector. Deze rapportage vormt de afsluiting van de zesde jaarcyclus van de Arbeidsmarktmonitor. Het rapport combineert de belangrijkste resultaten van het voor de monitor opgezette Werkgeverspanel Metalektro en de Quickscans met informatie uit diverse andere bronnen. Om dieper te kunnen ingaan op de achtergronden van de ontwikkelingen, problemen en knelpunten waarmee de bedrijven in de Metalektro te maken hebben, is een aantal gesprekken georganiseerd. Deze gesprekken vonden plaats tijdens regionale bijeenkomsten van bedrijven in de Metalektro. De gesprekken zijn verwerkt tot tekstkaders waarin de meningen van bedrijven over een aantal onderwerpen kernachtig samengevat worden. Deze kaders zijn door het hele rapport verspreid en gaan in op de wijze waarop bedrijven bepaalde ontwikkelingen en knelpunten in de praktijk ervaren en hoe ze daarmee omgaan. Ze zijn een waardevolle aanvulling op de informatie die in de hoofdtekst wordt gepresenteerd.

In 2007 zijn de metalektrobedrijven twee keer benaderd om mee te doen aan het werkgeverspanel. In iedere meting van dit panel beantwoordt een representatieve groep bedrijven uit de Metalektro via Internet een lijst met vragen over de in- en uitstroom van personeel in de zes maanden voorafgaand aan de meting en over het aantal openstaande vacatures. Naast deze standaardvragen wordt er in iedere meting ingegaan op bepaalde thema's zoals werving en selectie, de inzetbaarheid en de doorstroom van personeel, sociale en technologische innovatie en organisatorische vernieuwingen, en de competenties en scholing van het technisch personeel. Ook in 2006 is er weer veel aandacht besteed aan het verder verbeteren van de vraagstellingen in het werkgeverspanel. Door nieuwe vragen te introduceren en bestaande vragen verder aan te scherpen is geprobeerd om de informatie die het werkgeverspanel oplevert nog beter af te stemmen op de behoefte van de bedrijven.

Bij de start van het panel in 2002 zijn alle Metalektrobedrijven, die aangesloten zijn bij de werkgeversorganisatie FME-CWM en vallen onder de CAO Metalektro, benaderd om deel te nemen aan het Werkgeverspanel. Vanaf 2006 is dit panel aangevuld met een Quickscan die twee keer per jaar gehouden wordt. Daarin wordt de bedrijven gevraagd hun mening te geven over een vijftal stellingen. 
Om een representatief beeld te kunnen geven van de ontwikkelingen in de Nederlandse Metalektro wordt de informatie die de deelnemende bedrijven aanleveren gewogen naar bedrijfsomvang, bedrijfssector en regio. Om vervolgens uitspraken te kunnen doen over bijvoorbeeld het totale aantal vacatures dat in de Metalektro openstaat, is het aantal vacatures dat bij de deelnemende bedrijven openstaat opgehoogd. Deze ophoging van vacaturecijfers komt overeen met de procedure die het CBS volgt in hun landelijke vacature-enquête. Deze aanpak heeft als voordeel dat we een goed beeld kunnen geven van de ontwikkeling van het totale aantal vacatures dat er bij de bedrijven in de Metalektro openstaat. Ook de cijfers over de in- en uitstroom van werknemers in de Metalektro zijn opgehoogd tot in de tijd vergelijkbare totaalcijfers voor de hele sector.

$\mathrm{Na}$ iedere meting van het Werkgeverspanel Metalektro worden de uitkomsten gepubliceerd in een door de Stichting $\mathrm{A}+\mathrm{O}$ uitgegeven nieuwsbrief. In deze nieuwsbrief wordt niet alleen gerapporteerd over de actuele arbeidsmarktsituatie (vacatures, instroom en uitstroom, werkgelegenheidskrimp) en de arbeidsmarktverwachtingen voor de komende periode, maar komen ook andere trends en ontwikkelingen aan de orde. Daarnaast gaan we in iedere nieuwsbrief in een redactioneel commentaar in op de dynamiek in de Metalektro en de situatie op de arbeidsmarkt. Door de ontwikkelingen in de Metalektro in een wat breder perspectief te plaatsen wordt meer inzicht gegeven in wat de gevolgen van bepaalde trends en problemen zijn en wat dit voor het beleid kan betekenen. Ieder deelnemend bedrijf ontvangt ook nog een bedrijfsfoto. Dit benchmarkinstrument vergelijkt de positie van het eigen bedrijf met het algemene beeld van de bedrijfstak.

De inbreng en de betrokkenheid van de deelnemende bedrijven blijft cruciaal om de Arbeidsmarktmonitor Metalektro verder te ontwikkelen en draagt er toe bij dat de monitor een instrument is vóór en dóór de bedrijven. Daarom willen we de bedrijven die bereid waren om deel te nemen aan de verdiepende gesprekken van harte bedanken. De uitvoering van de Arbeidsmarktmonitor Metalektro en het samenstellen van deze jaarrapportage staat onder leiding van een regiecommissie. Deze commissie bestaat uit de volgende leden: Henry de Groot (Stichting A+O), Rien Smit (FME-CWM), Hilde ter Doest (FNV Bondgenoten) en Maarten Brouwer (CentERdata). De auteurs van dit rapport willen de leden van deze regiecommissie hartelijk bedanken voor hun constructieve feedback en de wijze waarop ze het onderzoek begeleid hebben. Het veldwerk voor het Werkgeverspanel Metalektro is uitgevoerd door Maarten Brouwer en Marije Oudejans van CentERdata. Sander Dijksman (ROA) werkte mee aan de statistische analyses in dit rapport. Jasper van Loo (ROA) heeft tot het najaar 2007 dit project geleid en daarmee een belangrijke bijdrage geleverd aan de organisatie van het onderzoek. 


\section{Arbeidsmarktmonitor Metalektro ook op Internet}

De Arbeidsmarktmonitor Metalektro heeft een eigen plaats op het Internet. Op de website www.aometalektro.nl kunnen bedrijven (en andere geïnteresseerden) meer achtergrondinformatie over de arbeidsmarktmonitor vinden. Bedrijven die willen gaan deelnemen aan het werkgeverspanel kunnen zich online aanmelden. 0ok de nieuwsbrieven en deze jaarrapportage kunnen via de website gedownload worden. De website is ook te benaderen via www.ao-metalektro.nl 


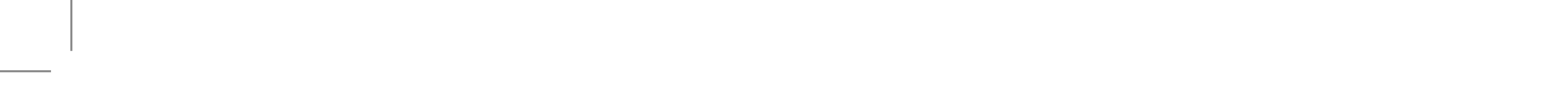




\section{Management Summary}

De werkgelegenheid binnen de metalektrosector heeft zich in het afgelopen jaar gestabiliseerd. Door de hoogconjunctuur profiteert de sector van een goed gevulde orderportefeuille. De sector is erin geslaagd de werkgelegenheid licht uit te breiden, met name door het sterk verminderen van de personeelsuitstroom. De metalektrobedrijven zullen echter de komende jaren geconfronteerd worden met een aanzienlijke uitstroom vanwege pensionering e.d., vooral van uitvoerend technisch personeel. Hierdoor is de huidige krapte op de arbeidsmarkt voor technisch personeel geen conjunctureel verschijnsel. Door de grote vervangingsvraag in combinatie met een relatief lage arbeidsmarktinstroom van technisch opgeleide jongeren blijven de metalektrobedrijven de komende jaren met vacatureproblemen worden geconfronteerd.

Naast deze kwantitatieve personeelsproblematiek is er ook sprake van een structurele kwalitatieve problematiek. Door productinnovaties en technologische en organisatorische innovaties van het productieproces is er in veel bedrijven sprake van een upgrading van de vereiste vaktechnische competenties. Bovendien is er een toenemende behoefte aan personeel dat beschikt over andere, niet-vaktechnische, competenties.

Wat betekenen deze ontwikkelingen in de Metalektro voor het beleid dat de bedrijven de komende jaren moeten gaan voeren? We vatten de belangrijkste punten samen in de Agenda voor de Toekomst en gaan daarna op ieder punt kort in.

Veel metalektrobedrijven geven aan dat het wenselijk zou zijn om een goede langetermijn strategie te hebben voor het invullen van hun personeelsbehoefte. Startpunt van deze strategie is het in kaart brengen van de verwachte personeelsbehoefte voor de komende jaren. Vanuit deze lange termijn strategie moet worden bepaald in hoeverre de onderstaande 'agendapunten' binnen het bedrijf meer of minder accent krijgen. Om adequaat in te kunnen spelen op de te verwachten kwantitatieve en kwalitatieve personeelsproblematiek zullen de meeste metalektrobedrijven echter langs verschillende wegen hun HRM beleid moeten versterken:

\section{Opleidings- en ontwikkelingsbeleid}

Naast het investeren in vaktechnische vaardigheden, moeten de inspanningen om de upgradingdoelstellingen te realiseren, gericht worden op vijf essentiële gedragsmatige competenties, die we kunnen aanduiden als de POFI+ agenda:

- Probleemoplossend vermogen; 
- Omgaan met veranderingen;

- Omgaan met klanten;

- Flexibiliteit;

- Initiatief.

Metalektrobedrijven zullen in hun opleidings- en ontwikkelingsbeleid meer aandacht moeten schenken aan het versterken van de POFI+ competenties van hun technisch personeel. Daarbij dient er vooral meer aandacht te komen voor het versterken van het informele leren op de werkvloer.

\section{Wervingsbeleid}

Vanwege de toenemende vergrijzing en de afnemende instroom van schoolverlaters zullen bedrijven hun wervingskracht op de arbeidsmarkt moeten vergroten. Dit beleid moet zich richten op:

- Het bieden van een aantrekkelijk loopbaanperspectief aan nieuwe medewerkers;

- Het verder ontwikkelen van samenwerking met het onderwijsveld;

- Het verbeteren van het imago van de metalektrosector;

- Het zelf opleiden van nieuwe medewerkers.

\section{Loopbaanbeleid}

Het HRM moet zich meer gaan richten op het stimuleren van verschillende vormen van interne mobiliteit, niet alleen vanwege de innovatiedynamiek en de behoefte aan flexibiliteit, maar ook om het personeel aantrekkelijke loopbanen te kunnen bieden en ongewenst verloop te voorkomen. Door het creëren van functies waarin werknemers verschillende aan elkaar gerelateerde taken vanuit een eigen verantwoordelijkheid uitvoeren ontstaat hoogwaardige werkgelegenheid die werknemers boeit en bindt, en de aantrekkingskracht van de sector op de arbeidsmarkt vergroot.

\section{Levensfasebewust personeelsbeleid}

De verdere ontwikkeling van levensfasebewust personeelsbeleid dat gericht is op drie cruciale elementen:

- Een proactief levensfasebewust personeelsbeleid voor alle werknemers;

- Investeren in de competentieontwikkeling van het oudere personeel door scholing, functieroulatie en informeel leren;

- Zorgen dat oudere werknemers zo lang mogelijk productief aan de slag kunnen blijven door middel van een gericht Active Aging beleid;

- Het stimuleren van mobiliteit in de laatste loopbaanfase en het ontwikkelen van flexibele uittredemogelijkheden die aansluiten bij de behoeften van het bedrijf en de medewerkers.

\section{Sociale innovaties}

Veel van de bovenstaande agendapunten vereisen dat bedrijven op verschillende terreinen sociale innovaties weten te realiseren, die gericht zijn op het aantrekken 
en ontwikkelen van optimaal inzetbaar personeel. Dit vereist innovativiteit van het HRM-beleid, uiteraard binnen de mogelijkheden die het bedrijf hiervoor heeft. Om dit te kunnen realiseren moeten bedrijven, op soortgelijke wijze als ze dat bij technologische innovaties doen, meer aandacht geven aan de ontwikkeling van sociale innovaties.

\section{Verspreiding van good practices en HR-tools}

Kleinere en middelgrote bedrijven moeten de effectiviteit van het arbeidsmarkten personeelsontwikkelingsbeleid vergroten door samenwerking en kennisdeling op regionaal niveau en het verspreiden van good practices en bruikbare HR-tools.

\section{Opleidings- en ontwikkelingsbeleid}

De vereiste upgrading van het personeel en de toenemende vraag naar technici die beschikken over de gevraagde gedragsmatige competenties vergen aanzienlijke investeringen in training en opleiding voor het personeel. Het accent in het scholingsbeleid ligt nog steeds op de vaktechnische cursussen. Er zouden meer vaktechnische scholingen gecombineerd kunnen worden met het training van 'soft skills' zowel op de werkvloer als in de scholen. Meer dan de helft van de bedrijven geeft echter aan dat ze de komende jaren de trainingen meer willen richten op het verbeteren van het probleemoplossend vermogen van hun personeel, terwijl een op de vijf bedrijven aangeeft dat ze meer aandacht willen gaan schenken aan cursussen die gericht zijn op het omgaan met veranderingen. Dit illustreert dat de metalektrobedrijven actiever invulling gaan geven aan de POFI+ agenda.

Daarentegen blijken de metalektrobedrijven nog niet meer aandacht te hebben voor het versterken van het informele leren op de werkplek, al geeft meer dan de helft van de bedrijven aan dat ze hun personeel door "on-the-job" training op veranderingen voorbereiden. Uit onderzoek blijkt dat het informele leren van zeer groot belang is voor de competentieontwikkeling van werkenden. Het lijkt ook bij uitstek de weg te zijn waarlangs medewerkers hun POFI+ competenties kunnen verbeteren.

\section{Wervingsbeleid}

Door de vergrijzing van het personeel en het veel te geringe aanbod van schoolverlaters neemt de krapte op de arbeidsmarkt toe. Daardoor moeten de metalektrobedrijven steeds vaker met andere bedrijven binnen en buiten de Metalektro concurreren om geschikt personeel te kunnen aantrekken. Ruim $40 \%$ van de bedrijven verwacht dat ze ook de komende jaren problemen zullen ondervinden bij de vervanging van hun uitvoerend technisch personeel.

Een derde van de bedrijven probeert deze vervangingsproblemen te verminderen door de inzet van arbeidsbesparende technologie. Het overgrote deel van de bedrijven kan er echter niet onderuit om het wervingsbeleid te intensiveren. Het op peil houden 
van de instroom van nieuw personeel vereist echter ook dat bedrijven meer gaan investeren in hun relaties met het onderwijsveld. Samenwerking met onderwijsinstellingen is cruciaal voor het vroegtijdig werven van toekomstig personeel. Ook kan langs deze weg worden meegesproken over de inhoudelijke aspecten van de opleiding. Veel bedrijven zijn al bezig om met onderwijsinstellingen samen te werken. De ervaringen zijn niet altijd even positief. Veel bedrijven zijn bezorgd over de vakinhoudelijke kennis van schoolverlaters. Ook beperkt de samenwerking met scholen zich vaak tot stages, e.d.

Om de wervingskracht van metalektrobedrijven te vergroten zullen bedrijven er naar moeten streven om "employer of choice" te worden. In de huidige "war for talent" zullen bedrijven dit alleen kunnen realiseren als ze met name jongeren goede ontwikkelingsmogelijkheden en een aantrekkelijk loopbaanperspectief weten te bieden. Dit is immers precies het punt waarop de keuze voor techniek momenteel de concurrentieslag met de economisch-administratieve en commerciële functies verliest.

\section{Loopbaanbeleid}

Het bieden van goede ontwikkelingsmogelijkheden en een aantrekkelijk loopbaanperspectief aan schoolverlaters is natuurlijk niet alleen van belang voor het vergroten van de wervingskracht van de metalektrobedrijven. Door duidelijke loopbaanperspectieven te bieden zullen de bedrijven er ook beter in slagen om het personeel dat ze aantrekken en in huis hebben te "boeien en binden", waardoor ongewenst personeelsverloop wordt voorkomen. Een goed loopbaanbeleid creëert voor het bedrijf zelf ook mogelijkheden om de inzetbaarheid van hun personeel te vergroten en daardoor flexibeler in te kunnen spelen op verschuivingen in de vraag op de afzetmarkt. Bovendien kan het een belangrijke bijdrage leveren aan de innovatiedynamiek en het ontstaan van een productief werkklimaat.

Het is belangrijk om HRM-instrumenten te gebruiken om met werknemers tot een loopbaanontwikkeling te komen. Het toenemend gebruik van functionerings- en scholingsgesprekken is een goede stap in de juiste richting. Het opstellen van persoonlijke ontwikkelingsplannen (POP's) kan hier in de toekomst nog meer structuur aan geven. Veel bedrijven willen dit instrument dan ook in de toekomst meer gaan inzetten.

In veel bedrijven is er sprake van interne promoties van technisch personeel naar hogere functies. Ook het inzetten op andere functies op hetzelfde niveau kan tot de ontwikkeling van werknemers bijdragen. Dit helpt bij het opbouwen van de nodige vakkennis voor de brede inzetbaarheid die door de bedrijven gewenst wordt en de employability van de werknemer.

Een goed loopbaanbeleid vereist ook een goed loopbaanmanagement. Hierdoor kan een werknemer doorgroeien qua competenties en verantwoordelijkheden. Ook biedt het de mogelijkheid om jonge medewerkers die kampen met aansluitingsproblemen 
tussen de door hen gevolgde opleiding en de eisen die hun functie stelt een goed ontwikkelingspad te bieden. Vanzelfsprekend is een goed loopbaanmanagement ook nauw verbonden met het opleidingsbeleid van het bedrijf. In dat geval is er sprake van een personeelsontwikkelingsbeleid.

\section{Levensfasebewust personeelsbeleid}

Met het krapper worden van de arbeidsmarkt voor technisch opgeleiden wordt het voor de Metalektro steeds belangrijker om de vroegtijdige pensioenuitstroom van het oudere personeel zoveel mogelijk te beperken. Dit maakt het belangrijk om voldoende aandacht te hebben voor het op peil houden van de inzetbaarheid van oudere medewerkers. Het aantal bedrijven dat aangeeft dat een leeftijdsbewust personeelsbeleid de komende jaren een speerpunt vormt in het personeelsbeleid is echter vrijwel niet toegenomen. Tweederde van de bedrijven lijkt hier onvoldoende aandacht voor te hebben. Daar staat echter wel tegenover dat veel bedrijven wel degelijk specifieke maatregelen treffen die de vroegtijdige arbeidsmarktuitstroom van ouder personeel beperken. Zo probeert meer dan de helft van de bedrijven de inzet van oudere medewerkers te optimaliseren door hen in te zetten voor de kennisoverdracht naar jonge medewerkers. Ook meer in het algemeen krijgen oudere medewerkers vaak andere taken en verantwoordelijkheden. Ten slotte bieden steeds meer bedrijven de mogelijkheid tot deeltijdpensioen, om daarmee het vroegtijdige vertrek van ouder personeel dat nog goed inzetbaar is te beperken.

Levensfasebewust personeelsbeleid moet echter niet beperkt blijven tot aandacht voor oudere werknemers. Om de kennis en vaardigheden van het personeel op een optimale wijze te kunnen benutten is het van belang dat bedrijven ook voldoende aandacht blijven houden voor hun personeel dat nog niet vergrijsd is. Door er nu al voor te zorgen dat ook de wat jongere werknemers hun competenties en ervaring op de juiste wijze kunnen ontwikkelen en goede loopbaanperspectieven hebben, kunnen bedrijven ervoor zorgen dat deze mensen in elke leftijdsfase van grote waarde blijven voor het bedrijf.

\section{Sociale innovatie}

Het overgrote deel van de metalektrobedrijven geeft aan dat ze organisatieveranderingen hebben doorgevoerd die ze typeren als sociale innovatie. Bedrijven die sociale innovatie doorvoeren, zijn vaak ook de bedrijven die technologisch innoveren. Dit illustreert de complementariteit tussen technologische en sociale innovatie.

Ook voor de komende jaren zal er veel aandacht zijn voor dit soort innovaties. Daarbij denken veel bedrijven vooral aan veranderingen in de manier van werken om optimaal te kunnen profiteren van de voordelen van "lean manufacturing", het variabel inzetten van het personeel en andere vormen van teamgericht werken. Deze innovaties zijn primair bedoeld om de arbeidsproductiviteit te verhogen en een kwaliteits- 
verbetering van de producten te realiseren. Veel bedrijven beseffen echter ook dat ze op deze manier kwalitatief hoogwaardige werkgelegenheid kunnen bieden die de aantrekkingskracht die het bedrijf heeft op de arbeidsmarkt zal vergroten.

\section{Verspreiding good practices en HR tools}

Kleinere en middelgrote bedrijven blijken vaak onvoldoende mogelijkheden te hebben om hun personeelsontwikkelings- en arbeidsmarktbeleid op eigen kracht verder te ontwikkelen. Regionale samenwerking met andere bedrijven kan er toe bijdragen dat deze bedrijven mogelijkheden kunnen creëren om de knelpunten waarmee ze geconfronteerd worden te overwinnen. Dit is zeker het geval wanneer kleinere bedrijven onvoldoende informatie hebben over de mogelijkheden tot en de voor- en nadelen van verschillende sociale innovaties. Daarbij gaat het ook om de overdracht van "good practices". Het gaat hierbij vooral om het identificeren van initiatieven op het vlak van arbeidsmarkt- en personeelsbeleid die bij andere bedrijven effectief blijken te zijn.

De overdracht van good practices kan er ook toe bijdragen dat niet ieder bedrijf zelf op zoek hoeft te gaan naar de wijze waarop bepaalde sociale innovaties ontwikkeld en geïmplementeerd kunnen worden. Daarbij is het van groot belang dat de inzichten die verkregen zijn uit de good practices vertaald worden in een aantal toegankelijke, gemakkelijk hanteerbare en direct implementeerbare tools. Met behulp van deze concrete HR-tools kunnen veel bedrijven in de Metalektro de effectiviteit van hun arbeidsmarkt- en personeelsontwikkelingsbeleid vergroten. 


\section{Dynamiek en verandering in de Metalektro}

In dit hoofdstuk analyseren we de dynamiek die typisch is voor de Metalektrosector. In paragraaf I.I gaan we in op de conjuncturele ontwikkelingen in 2007. In paragraaf I.2 kijken we vervolgens naar de werkgelegenheidsontwikkeling van de afgelopen jaren. Ook karakteriseren we de typische werkgelegenheid in de sector. Paragraaf I.3 beschrijft de mate waarin technologische innovatie een rol speelt in de sector, terwijl paragraaf I.4 in gaat op de organisatorische veranderingen en sociale innovatie.

\subsection{Conjuncturele ontwikkelingen}

Het afgelopen jaar was er in de Metalektro nog steeds sprake van een gunstige conjuncturele ontwikkeling. Evenals in 2006 was er een toename van de productie. Na de laagconjunctuur in de jaren 200I-2003, en het voorzichtige aantrekken van de conjunctuur in 2004-2005, hebben de bedrijven nu weer meer met de typische problemen van de hoogconjunctuur te maken. De maandelijkse conjunctuurenquête van het CBS laat dan ook zien dat het aantal bedrijven met productiebelemmeringen in 2007 is toegenomen. Het gaat hier om cijfers voor de gehele Nederlandse industrie.

Figuur I.I laat de ontwikkeling van de productie van de Nederlandse industrie zien. De blauwe lijn geeft de maandelijkse verandering in de gerealiseerde productiecapaciteit weer. De zwarte lijn geeft de gemiddelde productiecapaciteit over de afgelopen twaalf maanden weer. Hieruit blijkt duidelijk dat er de laatste twee jaar sprake is geweest van een gestage uitbreiding van de capaciteit. Waar in de voorgaande jaren uitbreiding en krimp zich nog afwisselenden, was er in 2006 en 2007 geen maand met een krimp in de productie.

Figuur I.2 laat zien dat de groei van de productie er toe geleid heeft dat het percentage bedrijven dat productiebelemmeringen ondervindt is toegenomen. Van 20or tot medio 2006 was het tekortschieten van de vraag naar de producten de grootste productiebelemmering. Door de hoogconjunctuur lopen verschillende bedrijven echter tegen hun productieplafond aan: $7-8 \%$ van de bedrijven geeft dan ook aan dat hun productie belemmerd wordt door het tekortschieten van hun productiecapaciteit. Vanaf de tweede helft van 2006 beginnen ook de tekorten aan personeel vaker een productiebelemmering te worden. In 2007 is dit bij nog meer bedrijven het geval. Het beperkte aanbod van geschikt personeel op de arbeidsmarkt zet daarmee een rem op de bedrijvigheid. Het gebrek aan afzetmogelijkheden, meer een probleem van een laagconjunctuur, speelt nu nauwelijks meer een rol. 
HOOFDSTUK 1

Figuur 1.1

Productie en productiecapaciteit in 2007 (\% bedrijven)

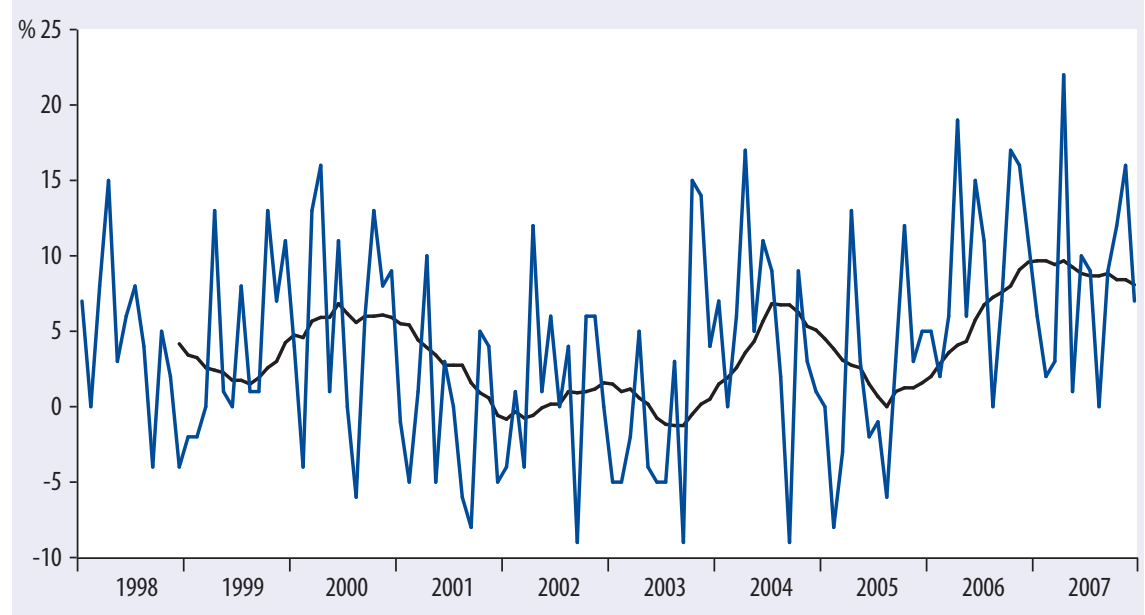

Bron: CBS / Conjunctuurenquête, 1998-2007

Figuur 1.2

Productiebelemmeringen in 2007 (\% bedrijven)

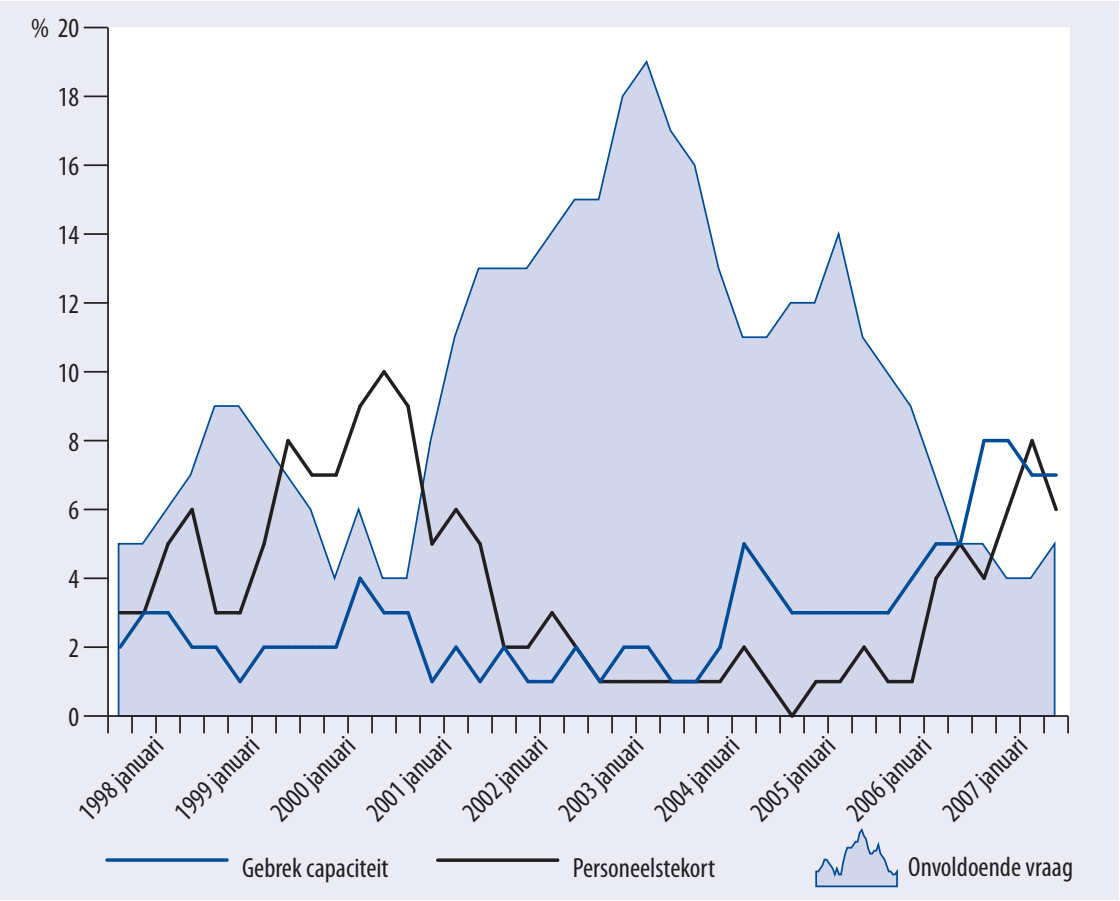

Bron: CBS / Conjunctuurenquête, 1998-2007 


\section{Figuur 1.3}

Bezettingsgraad 1998-2007

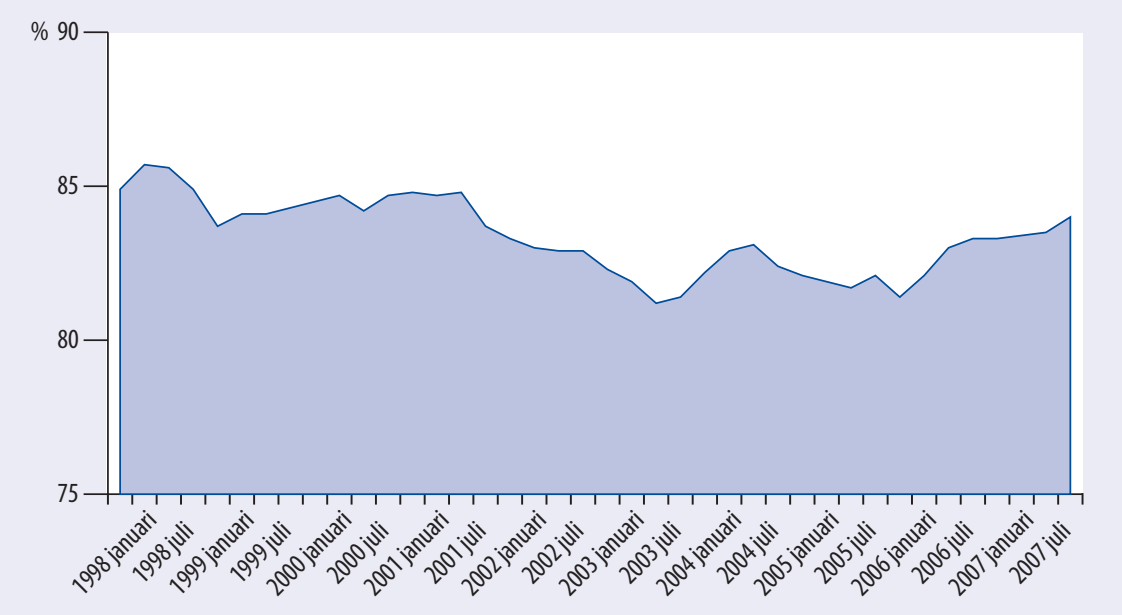

Bron: CBS / Conjunctuurenquête, 1998-2007

Figuur I.3 geeft de ontwikkeling van de bezettingsgraad van bedrijven in de industrie over de periode 1998-2007 weer. Hier is te zien dat, gemiddeld genomen, de bezettingsgraad nog niet aan zijn top zit. Daarbij moet wel beseft worden dat de figuur betrekking heeft op de gemiddelde bezettingsgraad. Een aantal bedrijven zal daarom nog resterende productiecapaciteit hebben, terwijl bij andere bedrijven de krappe productiecapaciteit al een belemmering is om aan alle opdrachten te kunnen voldoen. De bezettingsgraad geeft overigens geen belemmeringen weer, die door het gebrek aan personeel veroorzaakt worden.

\subsection{Werkgelegenheidsontwikkelingen op de lange termijn}

Zoals figuur I.4 laat zien is de lange termijn ontwikkeling van de totale werkgelegenheid in de Metalektro sector, volgens de brede definitie van het CBS, structureel dalend. De CBS cijfers laten echter zien dat deze personeelskrimp in de huidige hoogconjunctuur volledig tot stilstand is gekomen.

Dit beeld wordt bevestigd door de Arbeidsmarktmonitor Metalektro, waar de deelnemende bedrijven aangeven dat in het jaar 2007 de personeelsinstroom iets groter is dan de uitstroom van personeel. Er is dus sprake van een lichte groei van het aantal werkzame personen. Een gedetailleerde beschrijving van de in- en uitstroom over bedrijven is in hoofdstuk 2 te vinden. Het blijft natuurlijk wel afwachten of deze lichte personeelsgroei louter is toe te schrijven aan de huidige hoogconjunctuur, of dat de structurele daling van de werkgelegenheid tot stilstand is gekomen. 


\section{Figuur 1.4}

Ontwikkeling van het aantal werkenden in de Metalektro (index met 1996 als basisjaar), 1996-2006

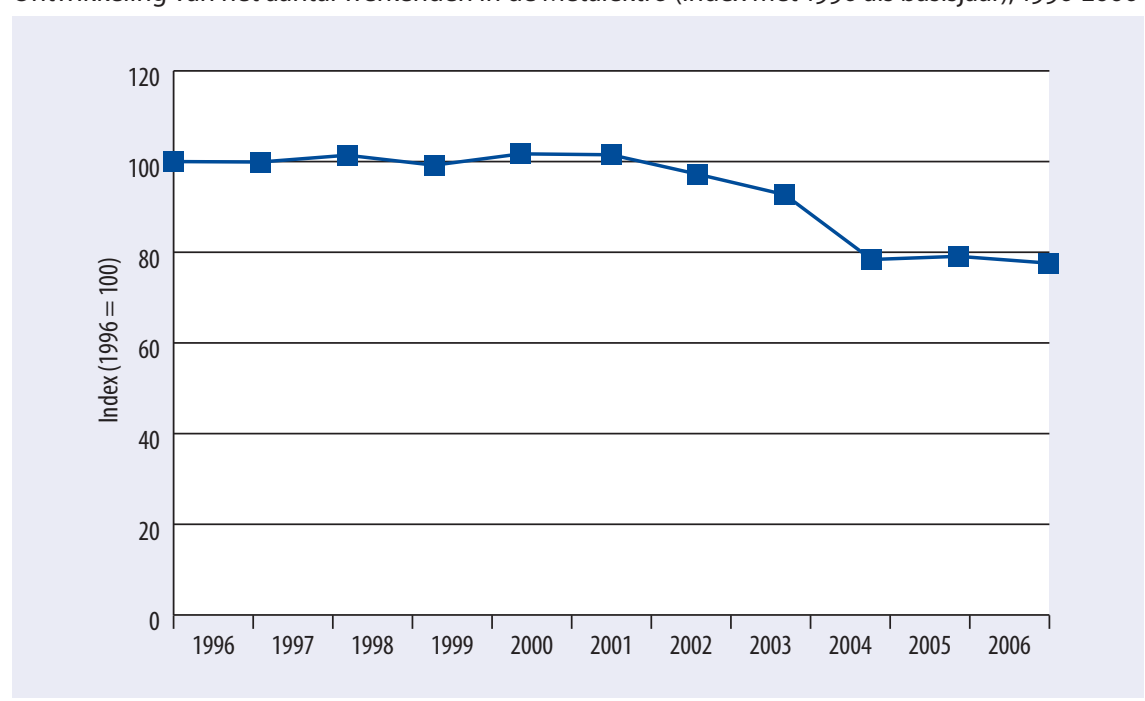

Bron: CBS / Enquête Beroepsbevolking, 1996-2006

Mede door de gekrompen werkgelegenheid in de afgelopen decennia, en met name de gekrompen instroom, kampt de Metalektro momenteel met een vergrijsd personeelsbestand. Meer dan $22 \%$ van de werknemers is 50 jaar of ouder, terwijl slechts $17,5 \%$ jonger is dan 30 jaar. Binnen de sector hebben de basismetaalbedrijven het oudste personeelbestand. Hier is slechtsı $2 \%$ van de werknemers jonger dan 30 , terwijl bijna $3 \mathrm{I} \%$ ouder is dan 50 .

Het is ook duidelijk dat de Metalektro nog steeds een mannendomein is, met een werkgelegenheidsaandeel van $87 \%$. Bij de bedrijven in de sector elektrotechniek werken relatief gezien nog de meeste vrouwen met een werkgelegenheidsaandeel van $23 \%$. Het aandeel allochtone werknemers blijft met gemiddeld $8,5 \%$ laag, waarbij de elektrotechnische bedrijven de minste allochtone werknemers hebben $(6,9 \%$ van de totale werkgelegenheid), en de basismetaal met $9,9 \%$ het hoogste aandeel.

Van de werkenden in de Metalektro heeft bijna de helft (49\%) een opleiding op middelbaar niveau (MBO) gevolgd. Daarentegen is $30 \%$ laag opgeleid (VMBO of lager), terwijl 2r\% een hoger opleidingsniveau ( $\mathrm{HBO}$ of WO) heeft. Uitschieters zijn de machine-industrie met een hoog aandeel middelbaar (52\%) en hoog opgeleiden $(27 \%)$, maar ook de sector Elektrotechniek waar $4 \mathrm{I} \%$ van de werkenden een MBO opleiding heeft, en liefst $39 \%$ een HBO of WO opleiding. 


\section{Figuur 1.5}

Percentage $\mathrm{MBO}$ en $\mathrm{HBO}$ schoolverlaters in de voor de sector relevante opleidingen dat werkzaam is in de Metalektro, per provincie, 2005-2006

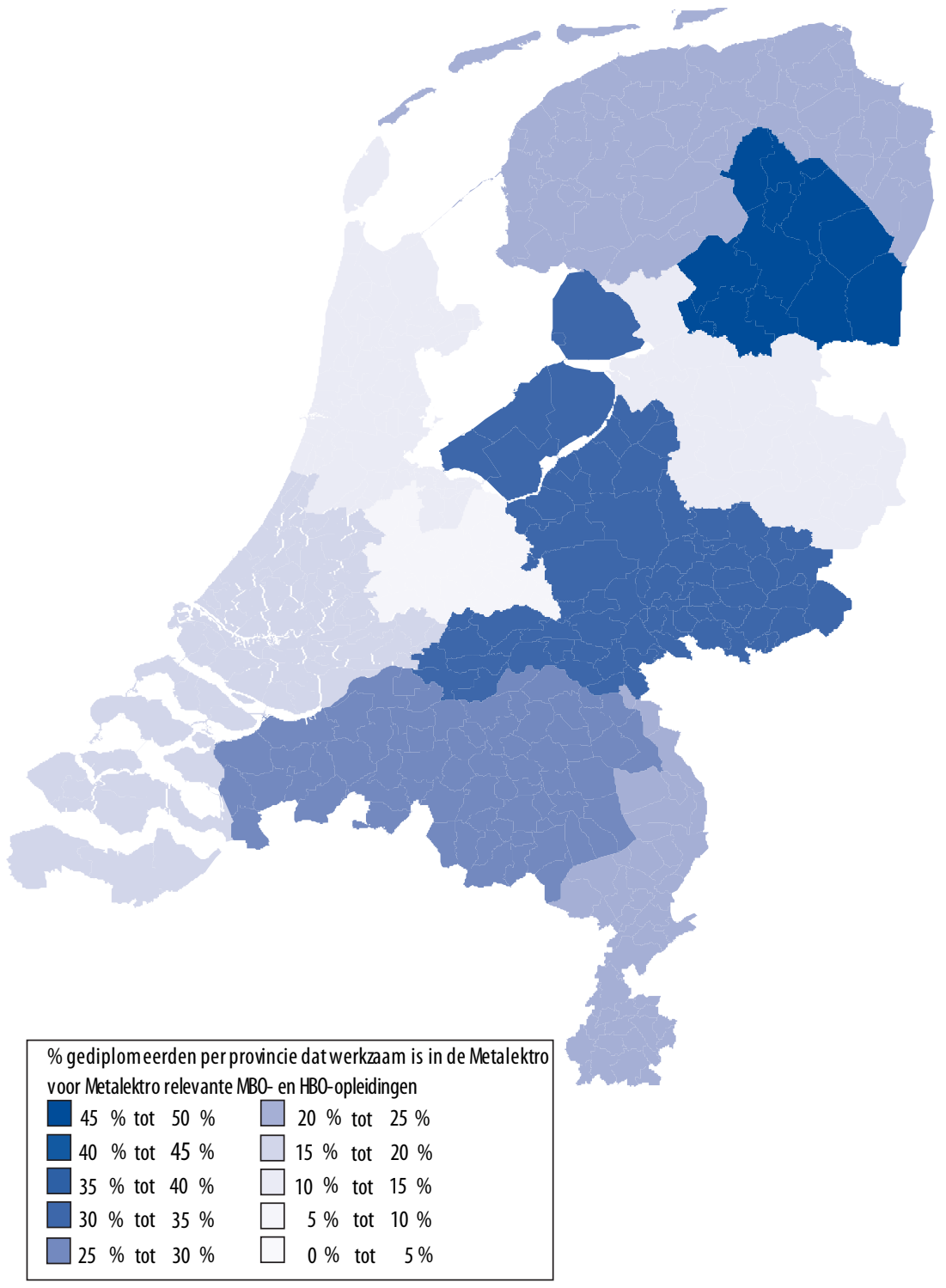

Bron: ROA / SIS, 2005-2006 
Binnen de Metalektro wordt voornamelijk in voltijd gewerkt. Bijna negen van de tien werknemers werkt voltijds. In de sector Elektrotechniek, waar ook een hoger aandeel vrouwen werkt, werken de meeste deeltijders. In deze sector heeft $15 \%$ van de werkenden een deeltijdcontract. Van alle werknemers die bij de metalektrobedrijven zelf in dienst zijn heeft $92 \%$ een vast dienstverband.

Een van de grote uitdagingen van de Metalektro zal zijn om schoolverlaters, met een relevante opleiding, aan zich te binden. Figuur I.5 geeft een overzicht van het percentage afstudeerders dat in een provincie in de Metalektro werk gevonden heeft. Hiervoor richten wij ons op opleidingen in $\mathrm{HBO}$ en $\mathrm{MBO}$ die bijzonder relevant zijn voor de Metalektro: $\mathrm{HBO}$ elektrotechniek en werktuigbouwkunde, en de MBO opleidingen in de elektrotechniek en werktuigbouw. De informatie is gebaseerd op de schoolverlatersenquête (SIS) van de jaren 2005 en 2006. Alle schoolverlaters van de relevante opleidingen worden op basis van hun werkprovincie meegeteld. De figuur geeft een soort "marktaandeel" van de sector bij het aantrekken van deze opleidingen weer. Veel westelijke provincies hebben duidelijk lagere percentages dan de noordoostelijke, en de zuidelijke provincies. Dit lagere aandeel zal mede met de kansen en alternatieven van de schoolverlaters te maken hebben. Het geeft ook aan dat de sector er hard aan moet trekken om deze werknemers voor zich te winnen.

\subsection{Technologische veranderingen}

Technologische veranderingen zijn voor de meeste bedrijven van de Metalektro dagelijks brood. Bij de productinnovaties gaat het zowel om producten die nieuw zijn voor de (wereld)markt, als om producten die al wel op de markt zijn, maar nieuw zijn voor het bedrijf. Zo wordt door de meeste bedrijven aangegeven dat er de komende vijf jaar een productinnovatie verwacht wordt (zie figuur I.6).

Naast de productinnovaties innoveren veel bedrijven ook hun productieproces. Deze procesinnovaties zorgen voor betere producten, tegen lagere prijzen en verbeteren vaak ook de flexibiliteit van het productieproces. Een groot deel van de bedrijven geeft aan dat ze de komende vijf jaar procesinnovaties zullen doorvoeren. $\mathrm{Bij} 48 \%$ van de bedrijven hebben deze procesinnovaties betrekking op het vernieuwen van productiemethoden, terwijl $44 \%$ van de bedrijven logistieke processen zal gaan vernieuwen en $38 \%$ onderhoudssystemen, e.d. gaat vernieuwen. 


\section{Figuur 1.6}

Verwachte innovatie in de Metalektro (\% bedrijven)

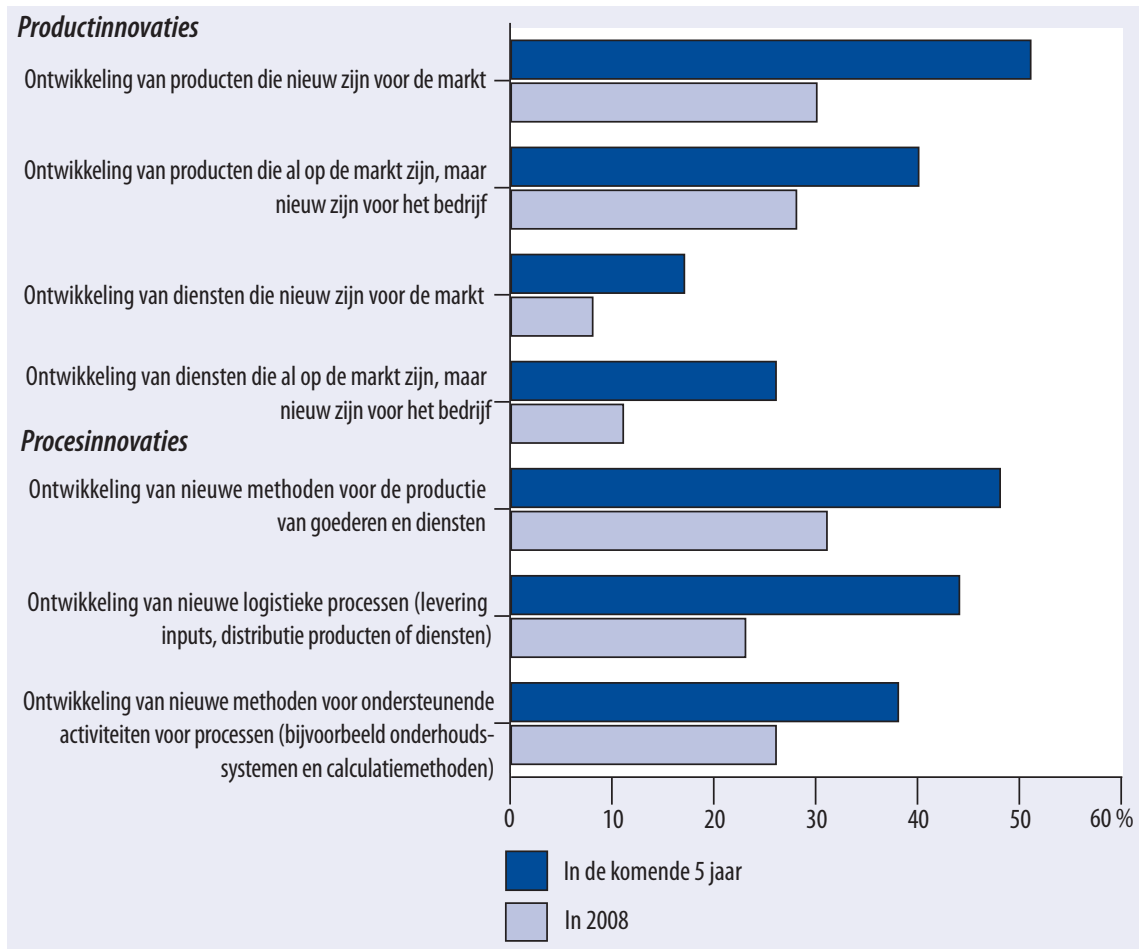

Bron: ROA / Werkgeverspanel Metalektro 2007

\subsection{Organisatorische veranderingen en sociale innovatie}

Voor een goede bedrijfsvoering is het ook van groot belang hoe het bedrijf met de nieuwe producten, productieprocessen, of werkvormen omgaat. Deze technologische innovaties vereisen vaak ook een andere inzet van werknemers. En om optimaal van deze product- en procesinnovaties te kunnen profiteren is het ook van groot belang dat ze in de productieomgeving gedragen worden door de werknemers.

Product- en procesinnovaties gaan daarom vaak gepaard met organisatorische veranderingen, die de nieuwe producten, productieprocessen, of andere vormen van innovaties met een nieuwe organisatie van het productieproces flankeren. Vaak is er ook een sterke wisselwerking tussen innovatie op het productvlak en nieuwe werkvormen of andere sociale innovaties binnen het bedrijf.

Figuur I.7 laat deze veranderingen zien zoals deze door bedrijven op korte (I jaar) en de middellange termijn ( 5 jaar) verwacht worden. Op de korte termijn zijn veel bedrijven 
gericht op de variabele inzet van hun personeel. Van deze sociale innovatie wordt in de Metalektro niet alleen een hogere productiviteit, maar ook een flexibilisering van de productie verwacht. Bijna een derde van de bedrijven wil al op korte termijn het aantal managementlagen verminderen. Opmerkelijk is ook dat veel bedrijven hun sociale innovaties richten op nieuwe vormen van teamgericht werken, Daarbij gaat het zowel om het vormen van multifunctionele teams, als om het creëren van zelfsturende teams en andere vormen van teamgericht werken. Ook verwachten veel bedrijven dat er de komende jaren meer taken van de afdelingen binnen het bedrijf worden geïntegreerd. Dit staat bij een kwart van de bedrijven al voor het komende jaar op de agenda, en voor bijna een derde van de bedrijven voor de komende vijf jaar. In hoofdstuk 6 zal verder op de relatie tussen sociale innovatie en product- en proces innovaties worden ingegaan.

\section{Figuur 1.7}

Sociale innovaties (\% bedrijven)

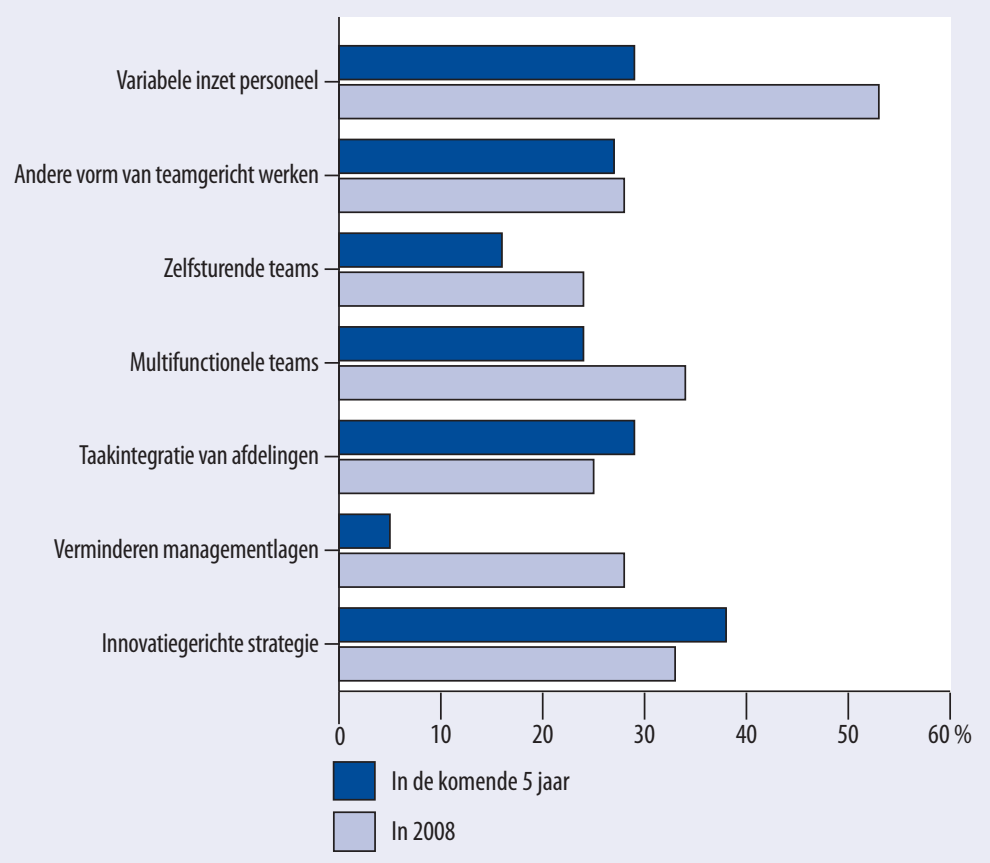

Bron: ROA / Werkgeverspanel Metalektro 2007 


\section{Arbeidsmarktontwikkelingen in 2007}

In dit hoofdstuk richten we ons op de arbeidsmarktontwikkelingen in de Metalektro in 2007. Ten eerste komen in paragraaf 2.I de ontwikkelingen in de personeelsinstroom in de Metalektro aan bod, waarna we in paragraaf 2.2 de personeelsuitstroom in 2007 onder de loep nemen. In paragraaf 2.3 gaan we vervolgens in op de algemene werkgelegenheidsontwikkelingen in de sector en beschrijven we onder andere de mate waarin bedrijven met een krimpende werkgelegenheid te kampen hebben en wat de gevolgen hiervan zijn. Ten slotte geven we in paragraaf 2.4 inzicht in de mate waarin metalektrobedrijven gebruik maken van uitzendkrachten en in hoeverre zij op een andere manier personeel flexibel inlenen.

\subsection{De personeelsinstroom in $\mathbf{2 0 0 7}$}

In deze paragraaf gaan we in op de personeelsinstroom in de metalektrobedrijven in 2007. We staan stil bij het percentage bedrijven waar nieuwe medewerkers instroomden, over hoeveel werknemers het in totaal gaat en in welk soort functies de nieuwkomers vooral zijn ingestroomd. In figuur 2.I wordt eerst per functiecategorie weergegeven welk deel van de bedrijven in de Metalektro nieuwe werknemers in dienst heeft genomen. In figuur 2.2 wordt vervolgens van de bedrijven die nieuwe medewerkers in dienst namen aangegeven hoeveel werknemers zij in totaal in dienst namen.

De meerderheid van de bedrijven in de Metalektro heeft in 2007 nieuwe werknemers voor uitvoerende technische functies aangenomen. In het tweede deel van 2007 nam $64 \%$ van de bedrijven nieuwe medewerkers voor deze functies in dienst. In de eerste helft van het jaar was dit percentage met $76 \%$ nog iets hoger. Ongeveer een derde tot de helft van de bedrijven in de Metalektro nam in 2007 medewerkers in dienst voor ondersteunende technische en niet-technische functies. Medewerkers voor leidinggevende functies en voor verkoopfuncties werden bij veel minder bedrijven nieuw aangenomen. Het is overigens, gezien het aantal werkenden in de verschillende functiecategorieën binnen een bedrijf, niet meer dan normaal dat er vaker nieuwe instroom van uitvoerende en ondersteunende technici is dan van leidinggevende functies of technisch opgeleide verkopers. 


\section{Figuur 2.1}

Instroom van nieuwe werknemers naar functiecategorie, 2007 (\% bedrijven)

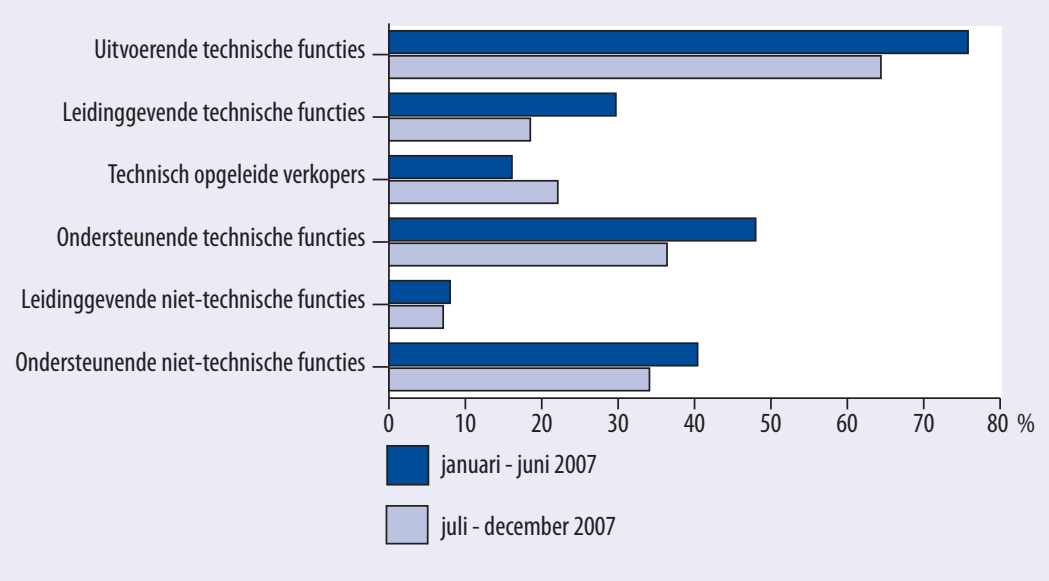

Bron: ROA / Werkgeverspanel Metalektro 2007

Voor alle functies, met uitzondering van de technisch opgeleide verkopers, namen in de eerste helft van 2007 meer bedrijven nieuwe medewerkers in dienst dan in de tweede helft van het jaar. Vooral nieuwe leidinggevende technische medewerkers werden tussen juli en december door veel minder bedrijven in dienst genomen dan in de eerste helft van het jaar.

\section{Figuur 2.2}

Instroom van nieuwe werknemers naar functiecategorie, 2007 (aantal werknemers)

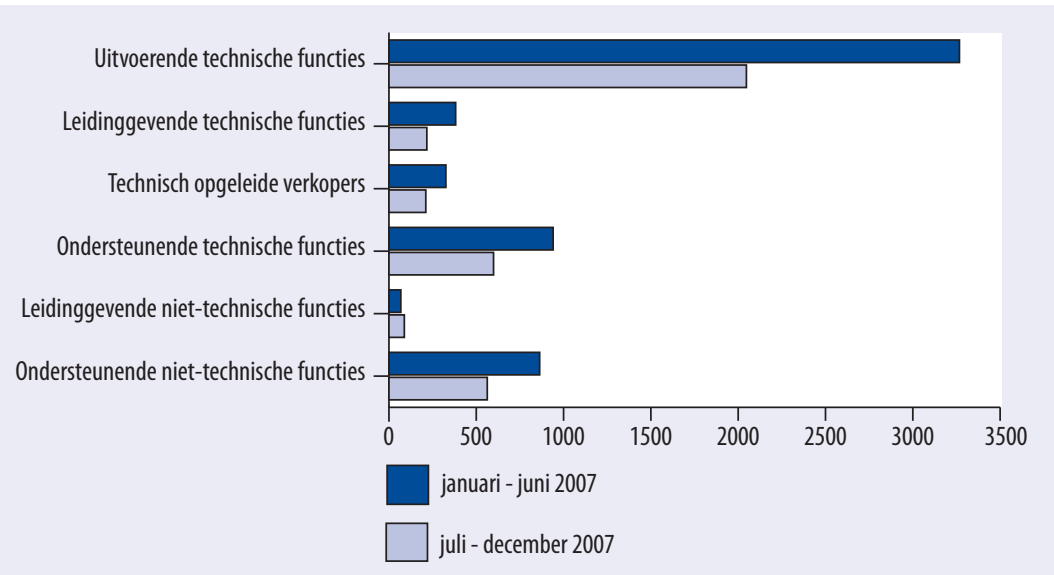

Bron: ROA / Werkgeverspanel Metalektro 2007 
In het totaal zijn er in 2007 ruim 9.550 nieuwe medewerkers bij een metalektrobedrijf in dienst getreden. Dit is een behoorlijke groei ten opzichte van de instroom van 8.230 nieuwe medewerkers in 2006.

Veruit de meeste nieuwe medewerkers zijn aangenomen voor uitvoerende technische functies. In de eerste helft van het jaar waren dit er ruim 3.250. Verder werden er ook veel nieuwe medewerkers in de ondersteunende technische en niet-technische functies in dienst genomen. Daarentegen zijn er betrekkelijk weinig nieuwe medewerkers voor leidinggevende niet-technische functies aangenomen. In lijn met figuur 2.I, zijn er in de tweede helft van 2007 veel minder werknemers in dienst genomen dan in de eerste helft van het jaar. Bij de uitvoerende technische functies daalde het aantal nieuwe medewerkers in de tweede helft van het jaar met ruim $37 \%$, terwijl bij de leidinggevende technische functies het aantal nieuwe medewerkers in de eerste helft van 2007 twee keer zo groot was als in de tweede helft van het jaar.

Als we deze instroom van nieuwe medewerkers in 2007 vergelijken met die in 2006, dan valt het op dat er vooral in de maanden januari tot en met juni 2007 veel meer nieuwe medewerkers bij de metalektrobedrijven zijn ingestroomd dan het jaar daarvoor. Het aantal nieuwe medewerkers in uitvoerende technische functies steeg van ongeveer 2.100 in 2006 naar ruim 3.250 in het eerste deel van 2007. In het tweede deel van het jaar is er daarentegen weer sprake van een daling ten opzichte van 2006: In de tweede helft van 2007 gingen er ongeveer 2.050 nieuwe werknemers in uitvoerende technische functies aan de slag bij een metalektrobedrijf, tegenover ruim 2.500 een jaar eerder. Al met al stroomden er in 2007 zo'n 700 uitvoerende technici meer in bij bedrijven in de Metalektro dan in 2006.

Kort samengevat was de personeelsinstroom in de Metalektro in de eerste helft van 2007 hoger dan in de eerste helft van 2006, terwijl de instroom in de tweede helft van 2007 lager was dan in de tweede helft van 2006. In het totaal was de personeelsinstroom in 2007 hoger dan in 2006.

\section{Sollicitanten "door de tent sleuren"}

Veel bedrijven hebben problemen met het op peil houden van de instroom. Toch kunnen sommige bedrijven uit een pool van sollicitanten kiezen: "Onze naamsbekendheid zorgt ervoor dat we veel open sollicitaties krijgen."Technici op MBO niveau lukt redelijk. Maar wij hebben ook redelijk wat te bieden. Hier kunnen ze op veel verschillende plekken terecht." Andere bedrijven moeten met uitzendkrachten werken: "Als ik 10 of 12 uitzendkrachten heb, dan blijven er uiteindelijk misschien 2." Als er een goede kandidaat komt opdagen, dan krijgt hij ook alle aandacht: "Wij sleuren sollicitanten door de tent, en de dag daarna krijgen ze een aanbieding." 


\subsection{De personeelsuitstroom in 2007}

In deze paragraaf geven we een beeld van de omvang van de personeelsuitstroom bij de bedrijven in de Metalektro. Per functiecategorie wordt weergegeven bij welk deel van de bedrijven er in 2007 medewerkers vertrokken. Vervolgens geven we de totale personeelsuitstroom per functiecategorie weer. Ten slotte laten we zien welk deel van de uitstroom voortkomt uit het met pensioen gaan van medewerkers.

In totaal verlieten in 2007 ongeveer 6.900 werknemers hun baan bij een bedrijf in de Metalektro. Dit is aanzienlijk minder dan in de jaren 2005 en 2006 toen respectievelijk ongeveer 9.400 en 8.000 werknemers bij een bedrijf in de Metalektro vertrokken. In 2006 vertrokken er overigens in de tweede helft van het jaar meer werknemers dan in de eerste helft van 2006. In 2007 was het omgekeerde het geval, al waren de verschillen tussen beide helften van het jaar veel kleiner dan in 2006 .

In figuur 2.3 wordt per functiecategorie het percentage metalektrobedrijven dat in 2007 werknemers zag vertrekken weergegeven. De figuur laat zien dat er in bijna alle functiecategorieën in de tweede helft van 2007 bij minder bedrijven in de Metalektro personeel uitstroomde dan in de eerste helft van 2007. Alleen de technisch opgeleide verkopers vormden op dit punt een uitzondering. Bij de meeste functiecategorieën zijn de verschillen echter klein.

\section{Figuur 2.3}

Uitstroom van werknemers, naar functiecategorie, 2007 (\% bedrijven)

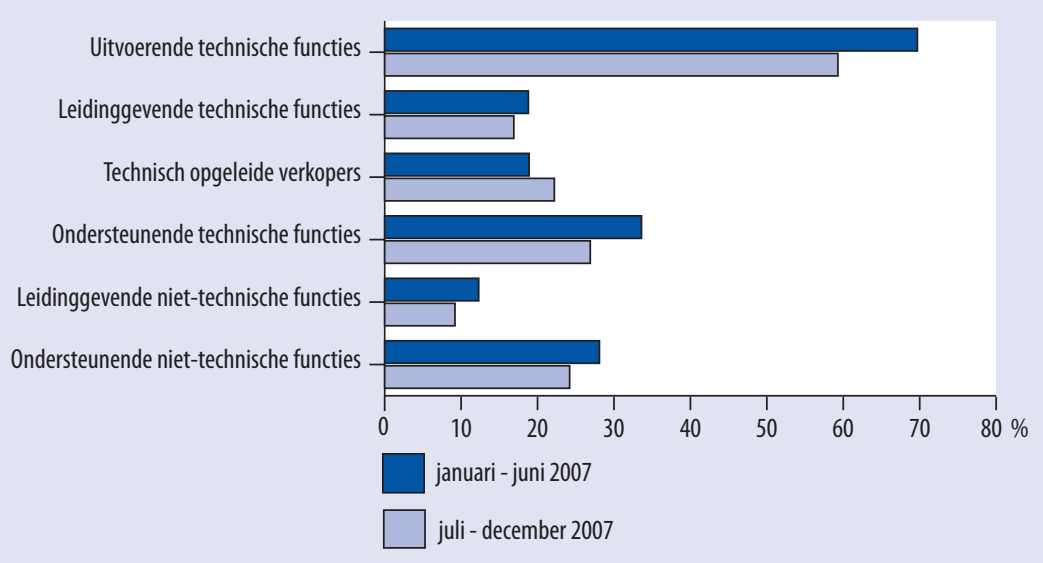

Bron: ROA / Werkgeverspanel Metalektro 2007

In het eerste deel van 2007 had ongeveer zeven van de tien bedrijven in de Metalektro te maken met werknemers die vertrokken zijn uit uitvoerende technische functies, in het tweede deel van 2007 is dit gedaald tot ongeveer zes op de tien bedrijven. Figuur 2.4 laat zien dat het verschil tussen januari - juni en juli - december 2007 veel groter 
is als we kijken naar het aantal uitgestroomde medewerkers. In de eerste helft van het jaar stroomden er in de uitvoerende technische functies nog ongeveer 2.250 werknemers uit bij de bedrijven in de Metalektro; in het tweede deel van het jaar waren dit er nog ongeveer I.35O.

\section{Figuur 2.4}

Aantal uitgestroomde werknemers naar functiecategorie, 2007

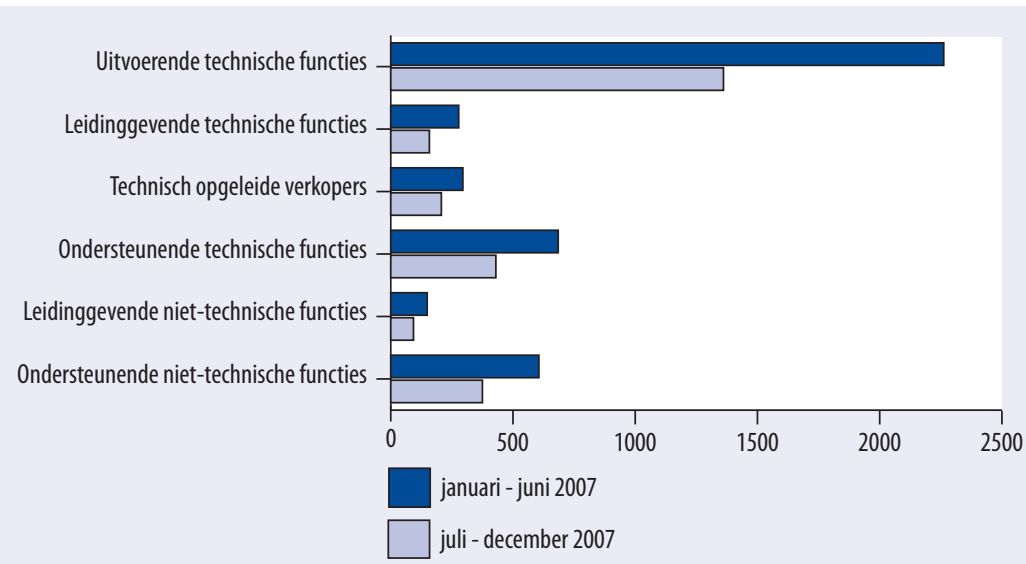

Bron: ROA / Werkgeverspanel Metalektro 2007

Aan de metalektrobedrijven is ook gevraagd welk deel van de vertrokken werknemers met pensioen is gegaan. Hieruit blijkt dat ruim de helft van de vertrokken leidinggevende technici bij een metalektrobedrijf met pensioen is gegaan. Dit is ook het geval bij bijna één op de drievertrokken werknemers in de uitvoerende technische functies en leidinggevende niet-technische functies. Bij de andere functies ligt dit percentage duidelijk lager.

\section{Figuur 2.5}

Aandeel werknemers dat vertrokken is door pensionering, 2007 (percentage bedrijven)

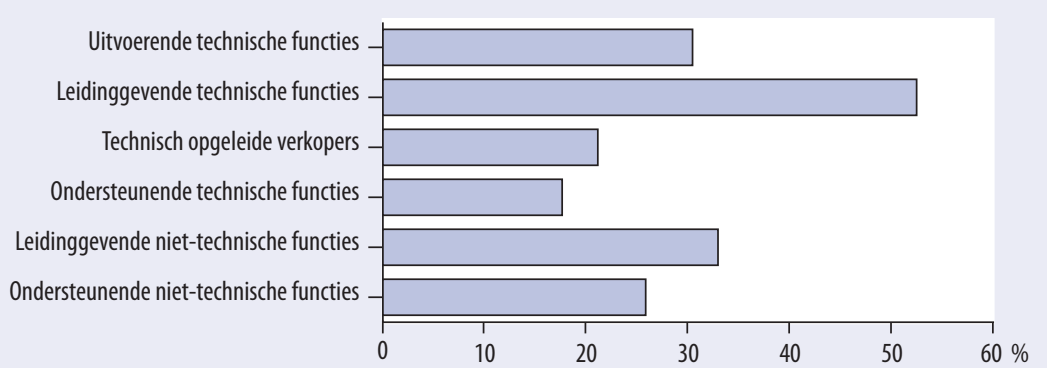

Bron: ROA / Werkgeverspanel Metalektro 2007 


\subsection{De werkgelegenheidsontwikkelingen in 2007}

\section{Krimpende werkgelegenheid in 2007}

Zoals in het vorige hoofdstuk reeds werd aangegeven is de totale werkgelegenheid in de Metalektro in 2007 toegenomen. Toch zijn er ook bedrijven waar de werkgelegenheid is gekrompen. Bovendien zijn er binnen de bedrijven verschuivingen in de structuur van de werkgelegenheid. In figuur 2.6 wordt per functiecategorie aangegeven hoeveel procent van de bedrijven in de Metalektro in 2007 te maken had met een krimpende werkgelegenheid.

\section{Figuur 2.6}

Krimpende werkgelegenheid naar functiecategorie, 2007 (\% bedrijven)

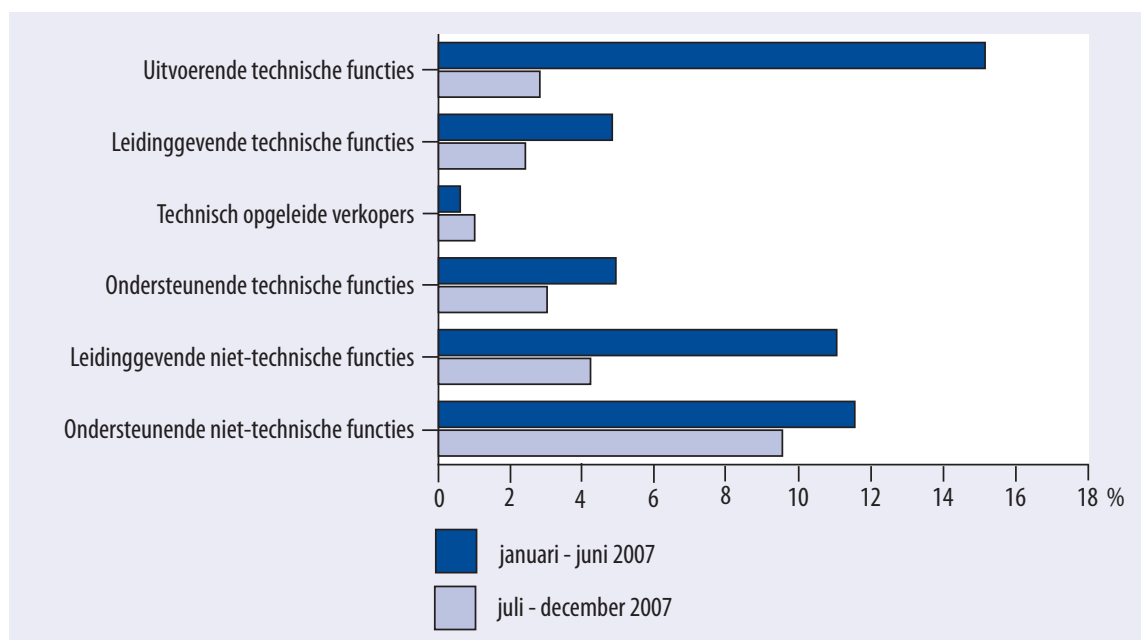

Bron: ROA / Werkgeverspanel Metalektro 2007

In de eerste helft van 2007 was er in $15 \%$ van de bedrijven sprake van een krimpende werkgelegenheid in de uitvoerende technische functies. In de tweede helft van 2007 had echter nog slechts 3\% van de bedrijven in de Metalektro een krimpende werkgelegenheid in deze functies. Ook voor bijna alle andere functiecategorieën waren er in de tweede helft van 2007 minder bedrijven met een krimpende werkgelegenheid dan in de eerste helft van het jaar. Bij de leidinggevende niet-technische functies (van II\% naar $4 \%$ ) en bij de leidinggevende technische functies (van $5 \%$ naar $2 \%$ ) daalde het aantal bedrijven met een krimpende werkgelegenheid ook sterk. Bij de technisch opgeleide verkopers was dit niet het geval. Er waren echter ook nauwelijks bedrijven waar de werkgelegenheid in deze functies in 2007 is afgenomen. 
In 2007 waren er ook minder metalektrobedrijven met een krimpende werkgelegenheid in alle functiecategorieën dan in 2006. In de tweede helft van 2007 zijn de verschillen ten opzichte van 2006 het grootst.

Aan bedrijven met krimpende werkgelegenheid werd ook gevraagd welke gevolgen de werkgelegenheidskrimp voor de bedrijven heeft. Aangezien er in het tweede deel van 2007 nog maar een klein deel van de metalektrobedrijven te kampen had met een krimpende werkgelegenheid baseren wij deze cijfers alleen op de eerste meting van 2007. Van de bedrijven die met krimpende werkgelegenheid te kampen hadden, zei ongeveer vier van de tien bedrijven werknemers naar andere functies binnen het bedrijf over te plaatsen. Eveneens vier van de tien bedrijven met krimpende werkgelegenheid zegt medewerkers die met pensioen gaan niet te vervangen. Bij bijna $25 \%$ van de bedrijven verlaten werknemers het bedrijf op eigen initiatief. Eenzelfde deel van de metalektrobedrijven verlengt tijdelijke contracten niet als gevolg van de krimpende werkgelegenheid binnen hun bedrijf.

\subsection{Flexibel inlenen}

Metalektrobedrijven vervullen hun personeelsbehoefte ook door gebruik te maken van uitzendkrachten, werknemers in te lenen of werknemers te detacheren. Figuur 2.7 geeft een beeld van de totale omvang van het aantal ingeleende werknemers in de Metalektro. In de eerste helft van 2007 werkten er in totaal bijna I6.00o werknemers in de sector die geen dienstverband hadden bij de metalektrobedrijven zelf. In de tweede helft van het jaar is dit aantal aanzienlijk geslonken tot bijna I0.50o. Het aantal ingeleende werknemers daalde dus met een derde. In bijna alle functiecategorieën werkten er in de tweede helft van 2007 veel minder werknemers zonder een dienstverband bij het Metalektrobedrijf zelf, dan in de eerste helft van 2007. Alleen bij de ondersteunende niet-technische functies was dit niet het geval.

Het blijkt dat verreweg het grootste deel van de ingeleende werknemers uitvoerende technici zijn. Van januari tot en met juni werkte er zo'n II.750 ingeleende werknemers in deze functies. Dit is maar liefst $74 \%$ van het ingeleende personeel. In de tweede helft van 2007 werkten er echter nog slechts 7.600 uitvoerende technici zonder dienstverband in de metalektrobedrijven. Voor andere functies doen metalektrobedrijven veel minder vaak een beroep op ingeleende werknemers, al worden ondersteunende technische en niet-technische functies nog wat vaker ingevuld door ingeleende werknemers. Er waren in 2007 ook enkele honderden leidinggevende technici zonder dienstverband werkzaam in de Metalektro, al nam dit aantal gedurende het jaar sterk af. Functies voor technische opgeleide verkopers en leidinggevende niet-technische functies werden nauwelijks door ingeleende werknemers uitgevoerd. 


\section{Figuur 2.7}

Aantal ingeleende werknemers naar functiecategorie, 2007

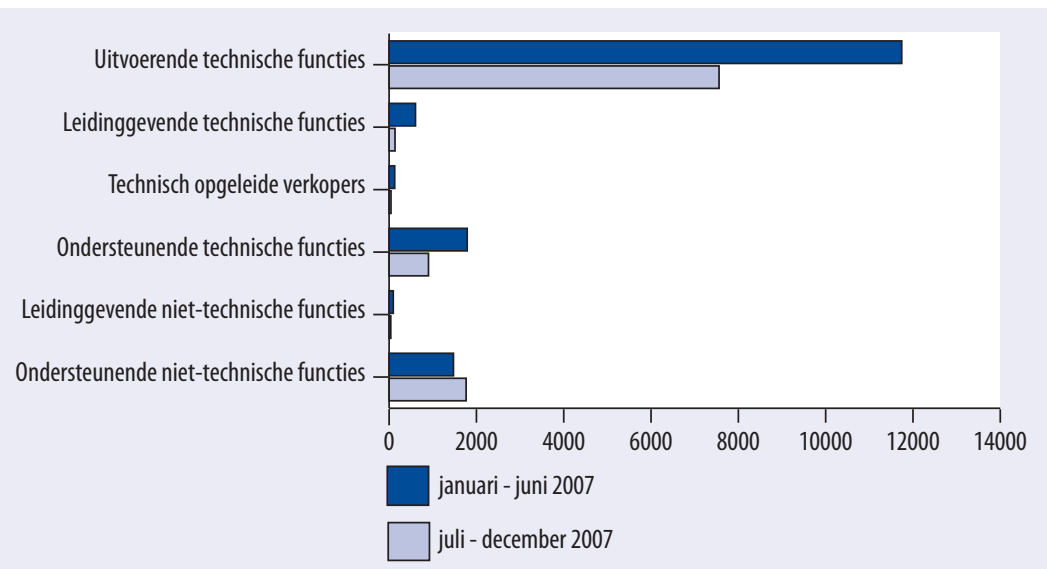

Bron: ROA / Werkgeverspanel Metalektro 2007 


\section{Het aantrekken van nieuw personeel}

In dit hoofdstuk richten we ons op het aantrekken van nieuw personeel en op de beweegredenen van het vertrekkend personeel. In paragraaf $3 . I$ gaan we in op de redenen van vertrek. In paragraaf 3.2 komen de ervaringen over de effectiviteit van de wervingskanalen aan bod. Paragraaf 3.3 geeft de ontwikkeling met betrekking tot de vacatures weer. Ten slotte wordt in paragraaf 3.4 een overzicht gegeven van de problemen die bedrijven ondervinden bij de werving van personeel.

\subsection{Verloop van personeel}

Het binnenhalen en binnenhouden van geschikte medewerkers wordt voor bedrijven in de Metalektro een steeds belangrijker aandachtspunt. Verschillende factoren, zoals de vergrijzing van het personeel, de aantrekkende economie en de relatief beperkte instroom van technische schoolverlaters, zorgen voor steeds meer krapte op de arbeidsmarkt voor technisch opgeleiden. De bedrijven in de Metalektro zullen de komende jaren dan ook steeds meer moeite moeten doen om hun vacatures te in te kunnen vullen.

Naast de uitstroom door de pensioneringvan medewerkers, hebben Metalektrobedrijven eveneens te maken met personeelsverloop. Daarbij gaat het om medewerkers die elders binnen of buiten de Metalektro gaan werken. In figuur 3.I wordt voor de bedrijven in de Metalektro weergegeven hoe ze het personeelsverloop in 2007 beoordelen ten opzichte van het jaar daarvoor.

Uit de figuur blijkt duidelijk dat weinig bedrijven aangeven dat er sprake is van veel verloop. Evenals in 2006 geeft geen enkel Metalektrobedrijf aan dat er ten opzichte van het voorgaande jaar erg veel verloop is. Wel geeft in 2007 15\% van de bedrijven aan dat er sprake was van veel personeelsverloop. Dit is drie keer zoveel als in 2006. Het percentage metalektrobedrijven dat zegt met weinig verloop te maken te hebben ten opzichte van het voorgaande jaar, is in 2007 echter behoorlijk gedaald van $39 \%$ tot $24 \%$. Daarentegen is het aantal bedrijven dat aangeeft erg weinig of geen verloop te hebben toegenomen. Deze ontwikkelingen duiden er op dat de verschillen tussen bedrijven op dit punt groter zijn geworden. Steeds meer bedrijven hebben te maken met veel personeelsverloop, of juist erg weinig of geen personeelsverloop. 


\section{Figuur 3.1}

Personeelsverloop in 2007 ten opzichte van een jaar eerder (\% bedrijven)

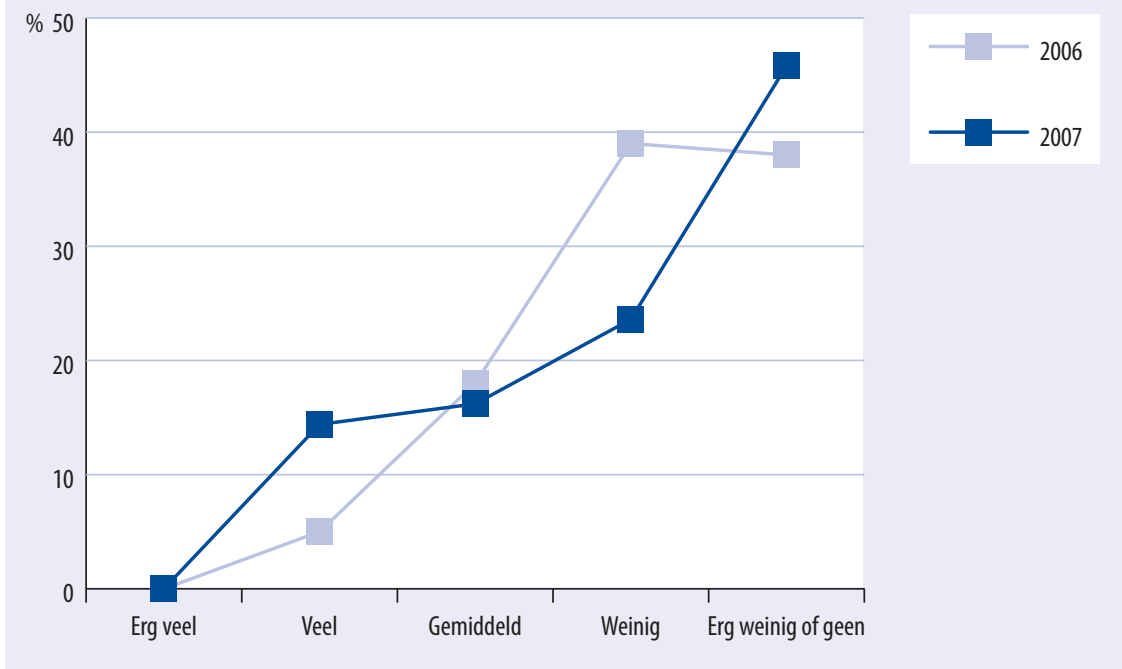

Bron: ROA / Werkgeverspanel Metalektro 2007

\section{Figuur 3.2}

De belangrijkste redenen voor vrijwillig vertrek van technisch personeel naar een ander bedrijf, 2007 (\% bedrijven)

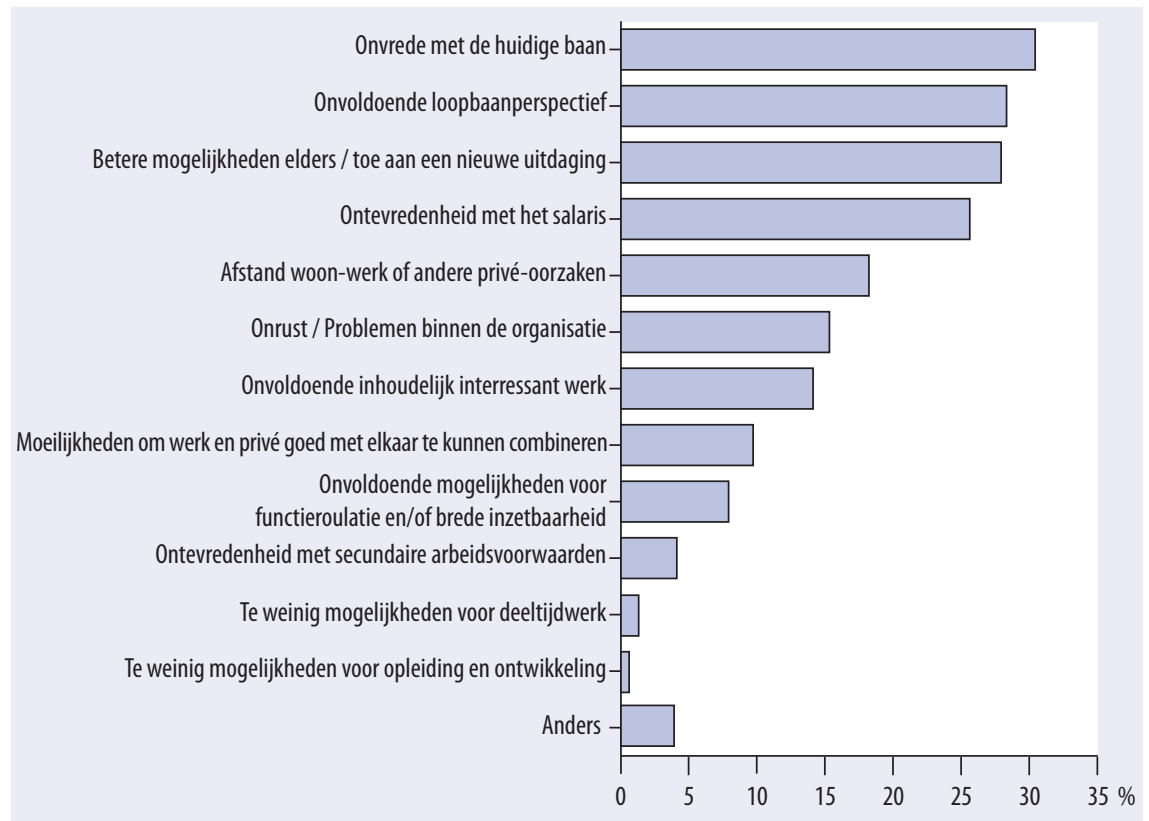

Bron: ROA / Werkgeverspanel Metalektro 2007 
In figuur 3.2 worden de belangrijkste redenen voor het vrijwillige vertrek van technisch personeel naar een ander bedrijf weergeven. Vooral onvrede met de huidige baan, onvoldoende loopbaanperspectief, betere mogelijkheden elders/ toe aan een nieuwe uitdaging en ontevredenheid met het salaris worden vaak als een belangrijke reden voor het vertrek van technische medewerkers genoemd. 25 tot 30\% van de bedrijven in de Metalektro noemt deze oorzaken voor het personeelsverloop. Andere redenen die relatief vaak door de Metalektrobedrijven genoemd worden zijn een te grote afstand van de woonplaats tot het werk, onrust of problemen binnen de organisatie en onvoldoende inhoudelijk interessant werk. Deze oorzaken voor het personeelsverloop worden door ongeveer $15 \%$ van de bedrijven genoemd. Te weinig mogelijkheden voor deeltijdwerk of voor opleiding en ontwikkeling zijn maar zelden een belangrijke reden voor het personeelsverloop. Het zijn dus vooral de primaire arbeidsvoorwaarden, de inhoud van het werk en de loopbaanperspectieven die het vertrek van technici naar andere bedrijven veroorzaken.

Wordt er door bedrijven veel gedaan om te voorkomen dat goede arbeidskrachten naar andere bedrijven vertrekken? In figuur 3.3 wordt een overzicht gegeven van de maatregelen die bedrijven in de Metalektro nemen om het verloop van hun technisch personeel naar andere bedrijven te voorkomen.

\section{Figuur 3.3}

Maatregelen ter voorkoming van het vertrek van technisch personeel naar andere bedrijven, 2007 (\% bedrijven)

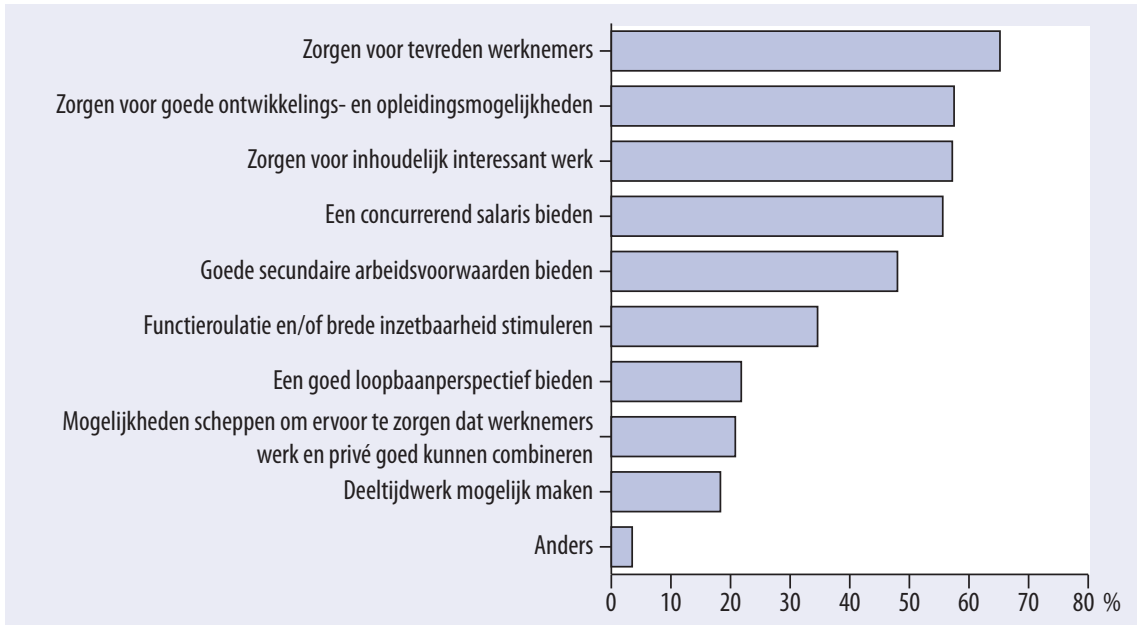

Bron: ROA / Werkgeverspanel Metalektro 2007

Metalektrobedrijven proberen het vertrek van technisch personeel naar andere bedrijven vooral te voorkomen door te zorgen voor tevreden werknemers. Tweederde van de bedrijven in de Metalektro geeft dit aan. Ook het creëren van goede ontwikkelings- en opleidingsmogelijkheden en zorgen voor inhoudelijk interessant werk 
worden vaak genoemd als middelen waarmee bedrijven proberen om hun technisch personeel in huis te houden. Zo'n $58 \%$ van de bedrijven noemt deze maatregelen, wat opmerkelijk is aangezien uit figuur 3.2 bleek dat slechts een beperkt deel van de vrijwillig vertrokken medewerkers dit als reden voor hun vertrek opgaven. Ditzelfde geldt ook voor het bieden van goede secundaire arbeidsvoorwaarden: De helft van de bedrijven in de Metalektro zet dit in als maatregel om het eigen technisch personeel binnen boord te houden, maar slechts $4 \%$ van de bedrijven geeft aan dat technisch personeel naar andere bedrijven verdwijnt vanwege betere secundaire arbeidsvoorwaarden. Het bieden van een goed salaris wordt, echter ook vaak ingezet als maatregel om technisch personeel aan het bedrijf te binden.

Veel minder vaak zetten bedrijven in de Metalektro in op het bieden van een goed loopbaanperspectief, of op het scheppen van mogelijkheden om werk en privé goed te kunnen combineren. Ongeveer één op de vijf bedrijven in de Metalektro doet dit. Dit is vreemd, gezien het hoge percentage bedrijven dat aangeeft dat werknemers vrijwillig vertrekken omdat ze elders betere loopbaanperspectieven hebben, of - zij het in wat mindere mate - omdat ze werk en privé niet voldoende kunnen combineren.

\subsection{Effectieve wervingskanalen}

In deze paragraaf wordt er ingegaan op de wervingskanalen die bedrijven in de Metalektro gebruiken en op de effectiviteit van deze wervingskanalen. Veruit de meest gebruikte maatregel die doorgevoerd wordt om moeilijk vervulbare vacatures in te vullen is het inschakelen van uitzendbureaus of andere commerciële werving- en selectiebureaus. Ruim driekwart van de bedrijven in de Metalektro schakelt een uitzend- of andere wervingsbureaus in om lang openstaande vacatures te vervullen. Nog eens bijna de helft van de bedrijven vult moeilijk vervulbare vacatures in door mensen met minder ervaring aan te trekken als men oorspronkelijk voor ogen had. Het actiever benaderen van scholieren, het bieden van goede loopbaanperspectieven, het aantrekken van anders opgeleiden, en het aantrekken van lager opgeleiden wordt door drie op de tien Metalektrobedrijven ingezet om moeilijk vervulbare vacatures te kunnen vervullen. In iets mindere mate gaan bedrijven er toe over om hun vacatures te vervullen door in het buitenland te werven of personeel collegiaal in te lenen bij andere bedrijven. Het bieden van een hoger salaris wordt door $15 \%$ van de bedrijven in de Metalektro ingezet. Gezien het feit dat veel personeelsverloop ontstaat door onvrede van het personeel met het salaris is het opmerkelijk om te zien dat slechts $15 \%$ van de bedrijven een hoger salaris wil aanbieden om maar deze moeilijk in te vullen vacatures te bezetten met geschikt personeel. Dit geeft duidelijk aan dat veel bedrijven beducht zijn voor het opdrijven van het salarisniveau, doordat men tegen elkaar gaat opbieden om in hun moeilijk vervulbare vacatures te voorzien. Verder is het opvallend dat er nauwelijks gebruikt wordt gemaakt van het CWI. Ongeveer I4\% van de Metalektrobedrijven gebruikt het CWI om hun moeilijk vervulbare vacatures in te vullen. Het inschakelen van een bureau voor arbeidsmarktcommunicatie, en het actiever benaderen van gedeeltelijk arbeidsongeschikten doet bijna niemand. 


\section{Figuur 3.4}

Wijze waarop bedrijven omgaan met moeilijk vervulbare vacatures voor technisch personeel, 2007 (\% bedrijven)

Inschakelen uitzendbureaus of andere commerciële werving en selectiebureaus

Aantrekken van mensen met minder ervaring

Actiever benaderen van scholieren

Bieden van goede loopbaanperspectieven

Aantrekken van anders opgeleiden (andere richting)

Aantrekken van lager opgeleiden (lager niveau)

Werven in het buitenland Collegiaal inlenen van personee

Bieden van hoger salaris

Inschakelen CWI (arbeidsbureau)

Competentiegericht werven

Bieden van betere, $C A 0$ overstijgende arbeidsvoorwaarden

Inschakelen bureau voor arbeidsmarktcommunicatie -

Actiever benaderen van gedeeltelijk arbeidsongeschikten -

Andere maatregelen -

Geen aanpassingen

\begin{tabular}{cccccccc|cc|}
\hline 1 & 1 & 1 & 1 & 1 & 1 & 1 & \\
0 & 10 & 20 & 30 & 40 & 50 & 60 & 70 & 80
\end{tabular}

Bron: ROA / Werkgeverspanel Metalektro 2007

\section{Naamsbekendheid door het sponsoren van de regionale sportverenigingen}

Voor technici van lager tot middelbaar niveau wordt vaak regionaal geworven: "We adverteren meestal in regionale dagbladen."Veel bedrijven benadrukken dat hiervoor ook een regionale naamsbekendheid opgebouwd moet worden. Een personeelsfunctionaris: "de naamsbekendheid is duidelijk omhoog gegaan door het sponsoren van de regionale sportverenigingen."

Sommige bedrijven hebben niet de benodigde capaciteit om voor de verschillende functies het juiste wervingskanaal te zoeken, zo maakt een manager van een MKB bedrijf duidelijk: "Vacatures worden vaak via het uitzendbureau ingevuld, deze hebben kennis van de juiste wervingskanalen". De verschillende functies moeten op verschillende manieren benaderd worden, zo beaamt een medewerker: "Het vinden van operators is voor ons makkelijk, problematischer is het vinden van specialistische ingenieurs." Voor hoger personeel gebruikt men graag selectiebureaus die specialistische kennis van zaken hebben. Maar het enthousiasme is niet onverdeeld: "Selectiebureaus vissen ook maar uit dezelfde vijver." Dit zorgt ervoor dat sommige bedrijven liever zelf adverteren in de printmedia zoals de intermediair voor specialistische functies. 
In figuur 3.5 wordt weergegeven hoe effectief de bedrijven in de Metalektro de verschillende maatregelen ter vervulling van moeilijk vervulbare vacatures vinden. We geven hier slechts de meest populaire maatregelen weer.

Figuur 3.5

Effectiviteit van de meest gehanteerde aanpassingen in werving en selectie, 2007 (\% bedrijven waarin aanpassingen doorgevoerd werden)

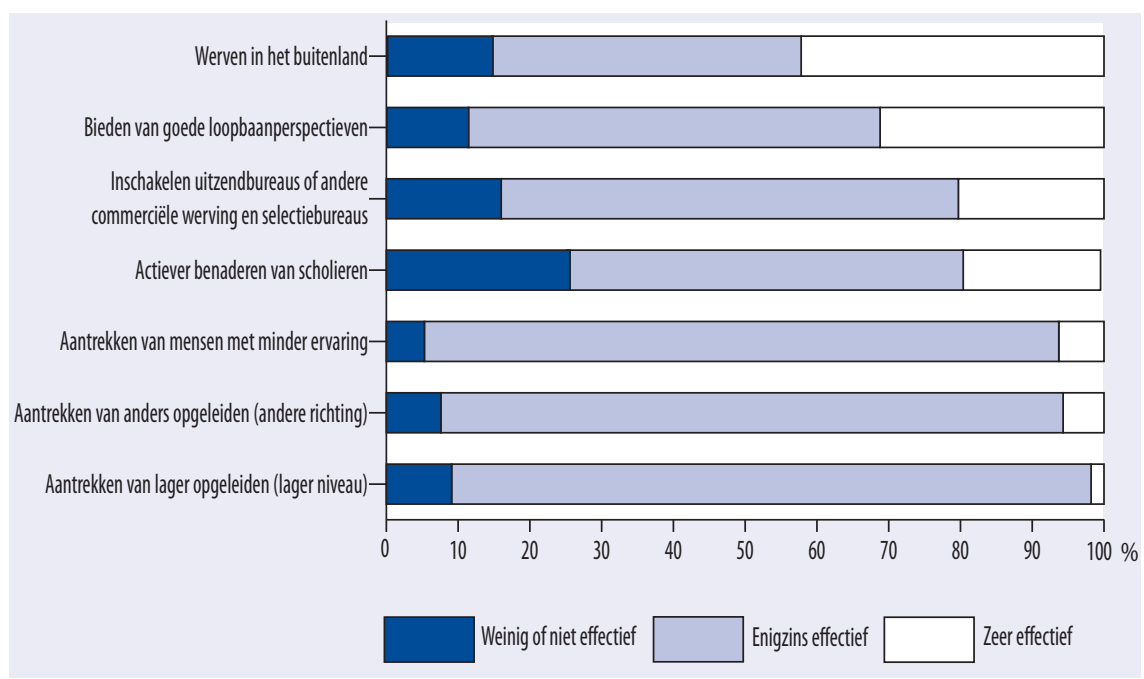

Bron: ROA / Werkgeverspanel Metalektro 2007

Werven in het buitenland wordt door een groot deel van de Metalektrobedrijven die dit doen als effectief bestempeld. Bijna negen van de tien bedrijven die moeilijk vervulbare vacatures proberen te vervullen door het bieden van goede loopbaanperspectieven vindt dit effectief. $20 \%$ van de Metalektrobedrijven die uitzendbureaus of andere commerciële werving- en selectiebureaus inschakelen, of actiever scholieren benadert, vindt dit zeer effectieve maatregelen. Overigens worden er weinig maatregelen als weinig of niet effectief beschouwd. Dit komt nog het meest voor bij het actiever benaderen van scholieren: Een kwart van de bedrijven die dit doet zegt dit weinig of niet effectief te vinden.

Figuur 3.6 geeft een beeld van wat bedrijven in de Metalektro het meest effectieve wervingskanaal vinden voor het aantrekken van nieuw technisch personeel. Daarbij wordt een vergelijking gemaakt tussen vier verschillende functiecategorieën. Metalektrobedrijven vinden het werven van uitvoerend technische medewerkers verreweg het meest effectief via een uitzendbureau. Bijna 3 op de ro bedrijven is deze mening toegedaan. Adverteren in een regionaal dagblad, een beroep doen op een commercieel wervingsbureau en internet gebruiken om uitvoerend technisch personeel te werven wordt door ongeveer 13 tot $16 \%$ van de Metalektrobedrijven als het meest effectieve wervingskanaal voor uitvoerende technici genoemd. IO\% van de bedrijven vindt informele wervingskanalen het meest effectief, terwijl $8 \%$ het werven via het eigen personeel in de bedrijfsvestiging het meest effectieve wervingskanaal voor uitvoerende 
technici vindt. Slechts $2 \%$ van de Metalektrobedrijven noemt het CWI als het meest effectieve wervingskanaal voor uitvoerend technisch personeel.

$29 \%$ van de bedrijven in de Metalektro vindt dat leidinggevend technisch personeel het meest effectief geworven wordt via een commercieel wervingsbureau. Ook het internet ( $19 \%)$ en adverteren in een regionaal dagblad ( $15 \%)$ worden relatief vaak als het meest effectieve wervingskanaal genoemd voor het aantrekken van leidinggevende technici. Informele kanalen, externe relaties en advertenties in landelijke dagbladen worden slechts door 6 a $8 \%$ van de Metalektrobedrijven als het meest effectieve wervingskanaal voor leidinggevende technici gezien.

Net als bij de leidinggevende technici worden bij de technisch opgeleide verkopers de commerciële wervingsbureaus $(32 \%)$ en het internet $(22 \%)$ het vaakst genoemd als het meest effectieve wervingskanaal. Andere wervingskanalen die nog relatief vaak genoemd werden als het meest effectief bij het aantrekken van technisch opgeleide verkopers zijn het adverteren in een regionaal (II\%) of landelijk dagblad (8\%), informele kanalen (IO\%), en het werven via externe relaties (8\%).

\section{Figuur 3.6a}

Meest effectieve wervingskanaal voor het werven van uitvoerend en ondersteunend technisch personeel, 2007, (\% bedrijven)

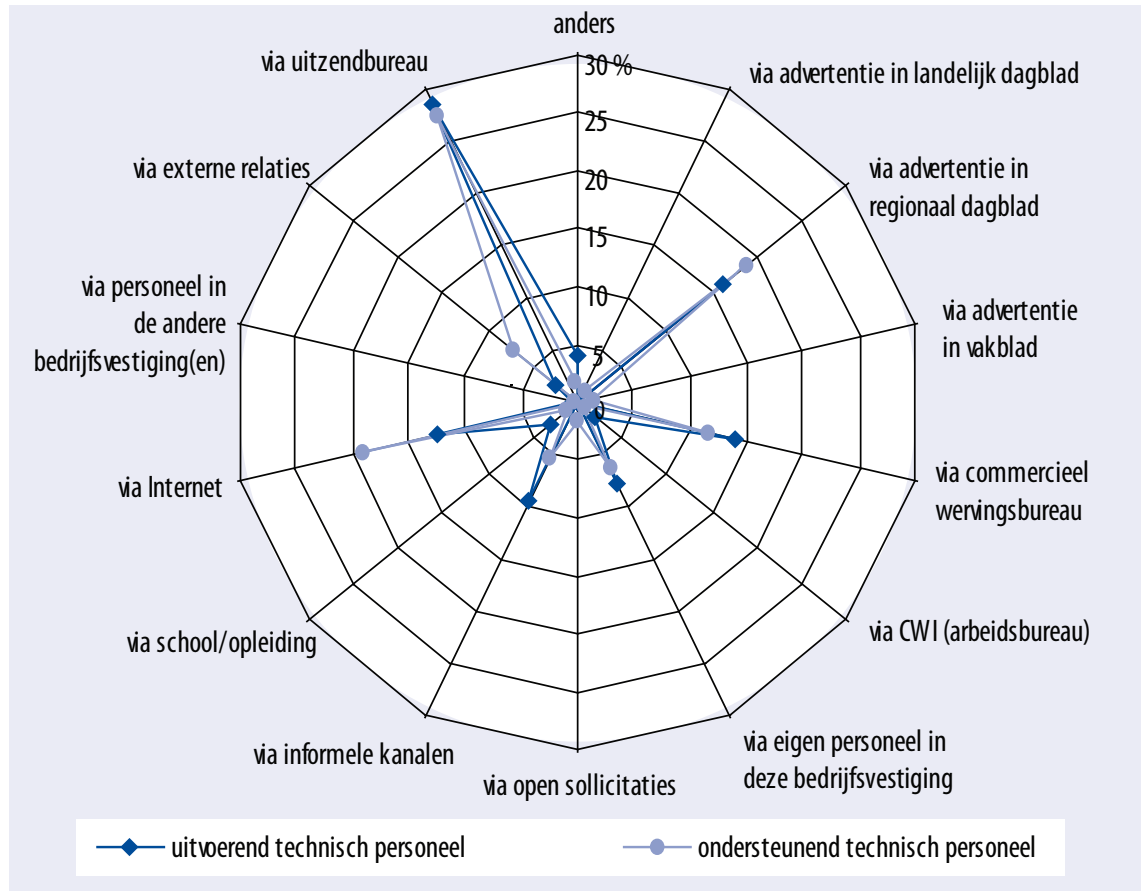

Bron: ROA / Werkgeverspanel Metalektro 2007 


\section{Figuur 3.6b}

Meest effectieve wervingskanaal voor het werven van leidinggevend technisch personeel en technisch opgeleide verkopers, 2007, (\% bedrijven)

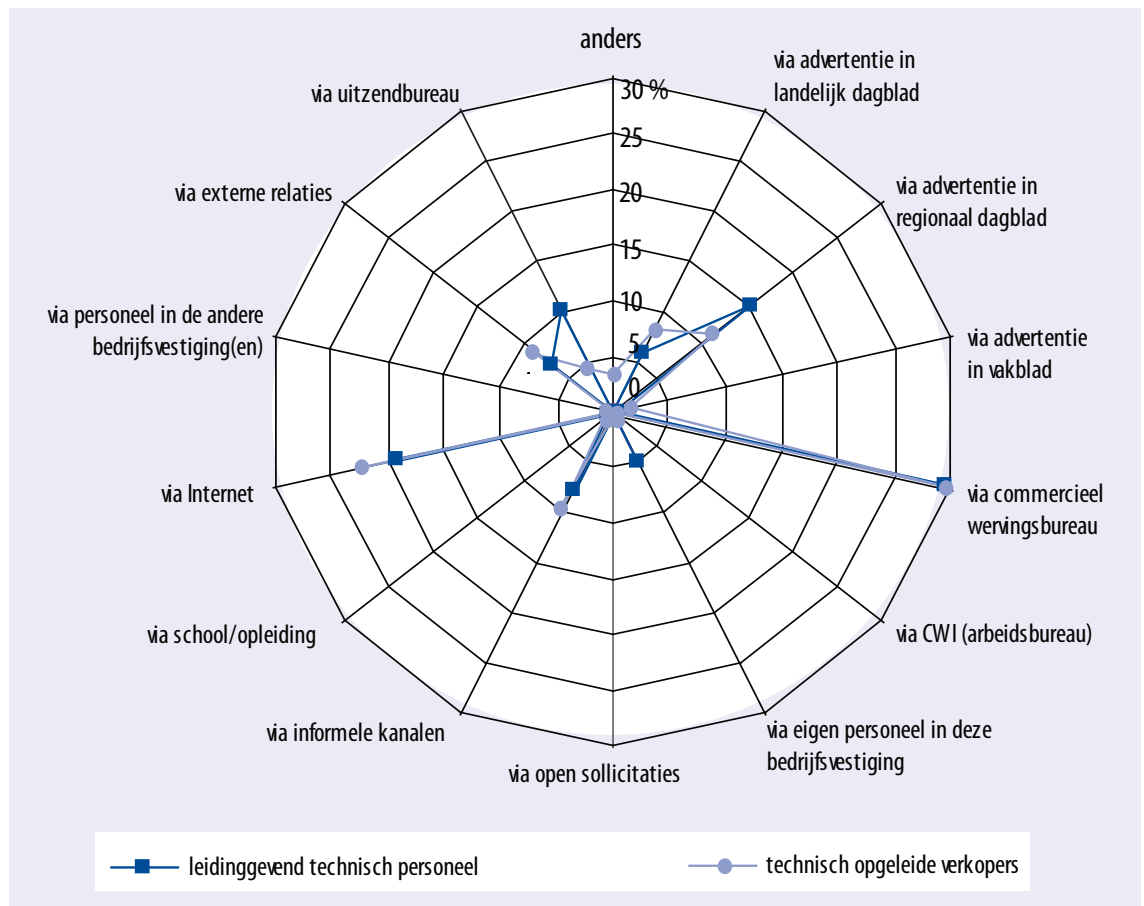

Bron: ROA/Werkgeverspanel Metalektro 2007

Bij het werven van ondersteunend technisch personeel, wordt net als bij het uitvoerend technisch personeel, een uitzendbureau het vaakst genoemd als het meest effectieve wervingskanaal. $27 \%$ van de bedrijven in de Metalektro vindt dit het meest effectief om aan ondersteunend technisch personeel te komen. $19 \%$ van de bedrijven vindt het internet het meest effectieve wervingskanaal voor deze functies en $17 \%$ het adverteren in een regionaal dagblad. Een commercieel wervingsbureau, externe relaties, het eigen personeel in de bedrijfsvestiging, en informele kanalen worden ook door een redelijk aantal bedrijven het belangrijkste wervingskanaal genoemd.

\section{Banners van ons op andere websites}

Het internet is ook een belangrijk hulpmiddel bij de werving. Zowel het gebruik van advertenties op het internet bij banensites als ook de eigen site worden als belangrijk ervaren: "We hebben een proef met landing sites. Hiermee komen er banners van ons op andere websites." Over de eigen site als achtergrondinformatie zegt een andere personeelsfunctionaris: "Als mensen over vacatures horen gaan ze vanzelf wel naar onze site. Dan is het wel belangrijk dat deze goed bijgehouden wordt." Maar niet alle mensen zijn gemakkelijk via het internet te werven: "Mensen die in de productie werken gaan's avonds als hobby internetten. Mensen die de hele dag achter een pc werken kunnen vaak 's avonds geen computer meer zien. Die lezen de krant." 
Figuur 3.7

Werving van technisch personeel via informele kanalen, 2007 (\% bedrijven)

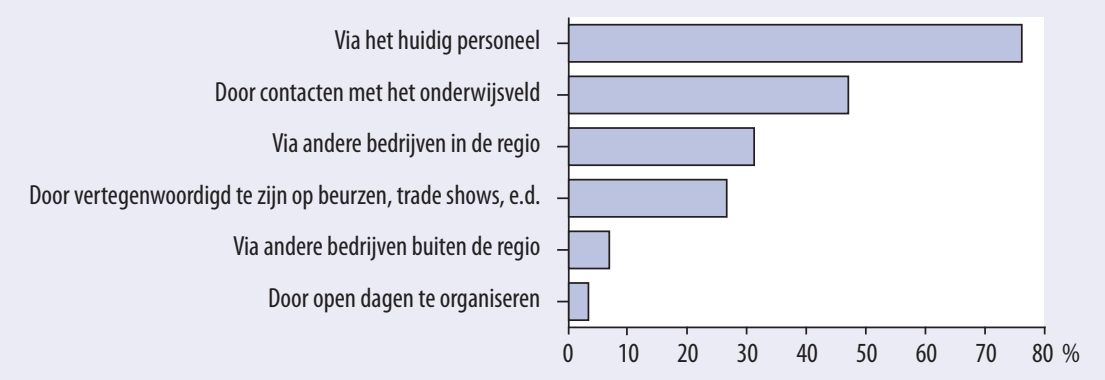

Bron: ROA / Werkgeverspanel Metalektro 2007

In 2007 is voor het eerst ook gevraagd op welke manieren bedrijven informeel werven. Figuur 3.7 laat zien op welke manieren bedrijven, die hun technisch personeel informeel werven, te werk gaan. Ruim driekwart van de bedrijven die informeel werven, doet dat door gebruik te maken van de contacten van het eigen personeel. In de praktijk zullen deze bedrijven bij het ontstaan van een vacature het eigen personeel vragen of men in de eigen kennissenkring geschikte kandidaten weet, die mogelijk interesse hebben in de openstaande vacature. Soms geven bedrijven ook premies aan medewerkers die nieuw personeel aanleveren. Bijna de helft van de bedrijven die informeel werven gebruikt de contacten met het onderwijsveld om informeel te werven. Daarbij zal het in de praktijk vaak gaan om het werven van leerlingen die in het kader van hun opleiding al werkzaam zijn in het bedrijf. $31 \%$ van de bedrijven werft informeel via andere bedrijven in de regio. Deze wervingsstrategie zal vooral effectief zijn wanneer bepaalde bedrijven in de regio overtallig personeel in dienst hebben. Ook beurzen en 'trade shows' zijn voor een aantal bedrijven een manier om personeel te werven. Ongeveer $27 \%$ van de bedrijven die informeel werven zien deze manifestaties als een effectief middel om op informele wijze personeel aan te kunnen trekken. Slechts $3 \%$ van de bedrijven die informeel werven doet dit door het organiseren van open dagen.

\section{Stagiaires als middel voor werving en selectie}

Een HRM manager van een bedrijf met ruim 100 medewerkers: "In engineering hebben wij altijd twee stagiaires, het is voor ons een belangrijk middel voor werving en selectie."'De meeste stagiaires krijgen bij ons een baan aangeboden." Gebruik maken van stagiaires kost ook tijd en aandacht. Niet alle bedrijven kunnen op elke plek stagiaires gebruiken: "Ons bedrijf kan - gezien het sensitieve karakter van onze producten - geen jonge stagiaires gebruiken." "Je moet er wel tijd voor vrijmaken, men moet mensen goed begeleiden." 


\subsection{Vacatures}

Met de aantrekkende economie van de afgelopen jaren is ook de krapte op de arbeidsmarkt toegenomen. Dit geldt zeker voor de Metalektro branche. In figuur 3.8 wordt de ontwikkeling van het totaal aantal vacatures in de Metalektro tussen 2002 en 2007 weergegeven. Figuur 3.9 laat zien welk percentage van de bedrijven openstaande vacatures heeft in de verschillende functiecategorieën. Ten slotte wordt in figuur 3.IO aangegeven hoeveel vacatures de bedrijven in de verschillende functiecategorieën hebben openstaan.

\section{Figuur 3.8}

Ontwikkeling totaal aantal vacatures in de Metalektro, 2002-2007

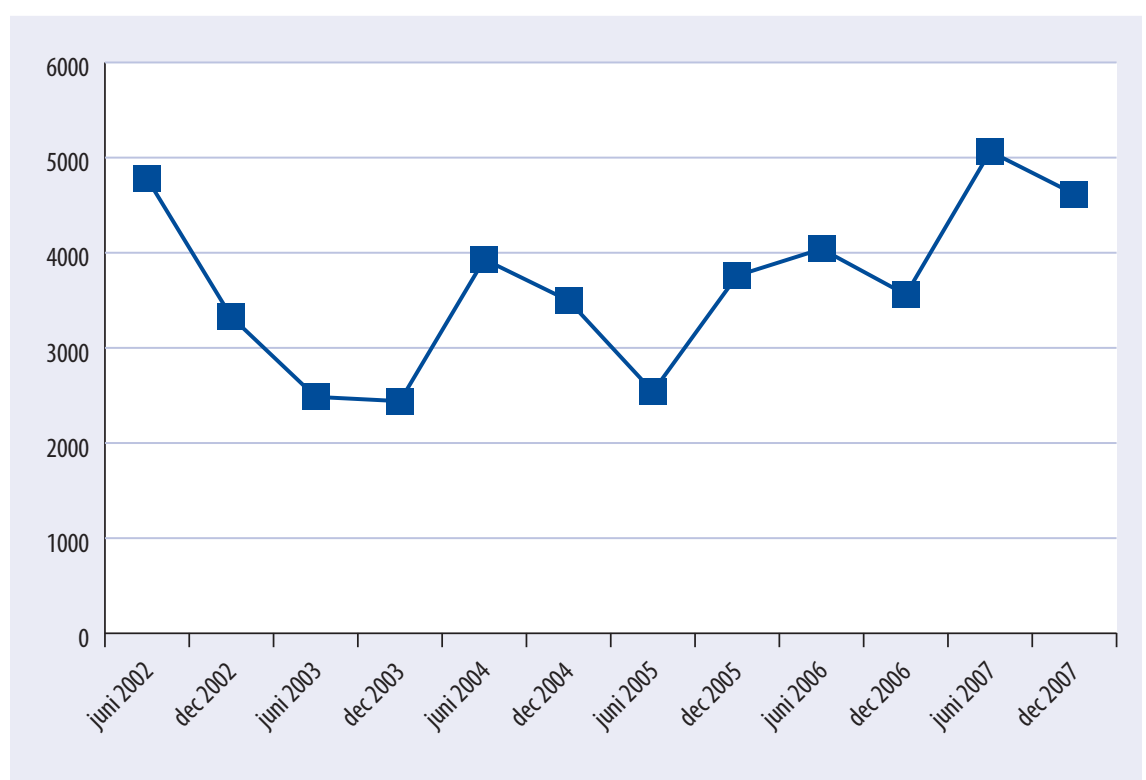

Bron: ROA / Werkgeverspanel Metalektro 2007

Uit figuur 3.8 blijkt dat na een sterke daling van het aantal vacatures in 2002 en 2003 , er sindsdien weer een forse stijging van het aantal vacatures in de Metalektro heeft plaatsgevonden. Tussen begin 2004 en eind 2006 bleef het aantal vacatures in de Metalektro min of meer schommelen tussen de 3.500 en 4.000 . Alleen in de eerste helft van 2005 was er nog forse daling tot ongeveer 2.500 vacatures. In het afgelopen jaar is het aantal vacatures in de Metalektro echter weer gegroeid. In de eerste helft van 2007 waren er bijna 5.I00 openstaande vacatures. In het tweede deel van het jaar liep dit weer iets terug tot 4.600 vacatures. Het wordt voor de Metalektrobedrijven dan ook steeds moeilijker om al hun openstaande vacatures in te vullen. 
Figuur 3.9

Percentage bedrijven in de Metalektro met openstaande vacatures, per functiecategorie, 2007

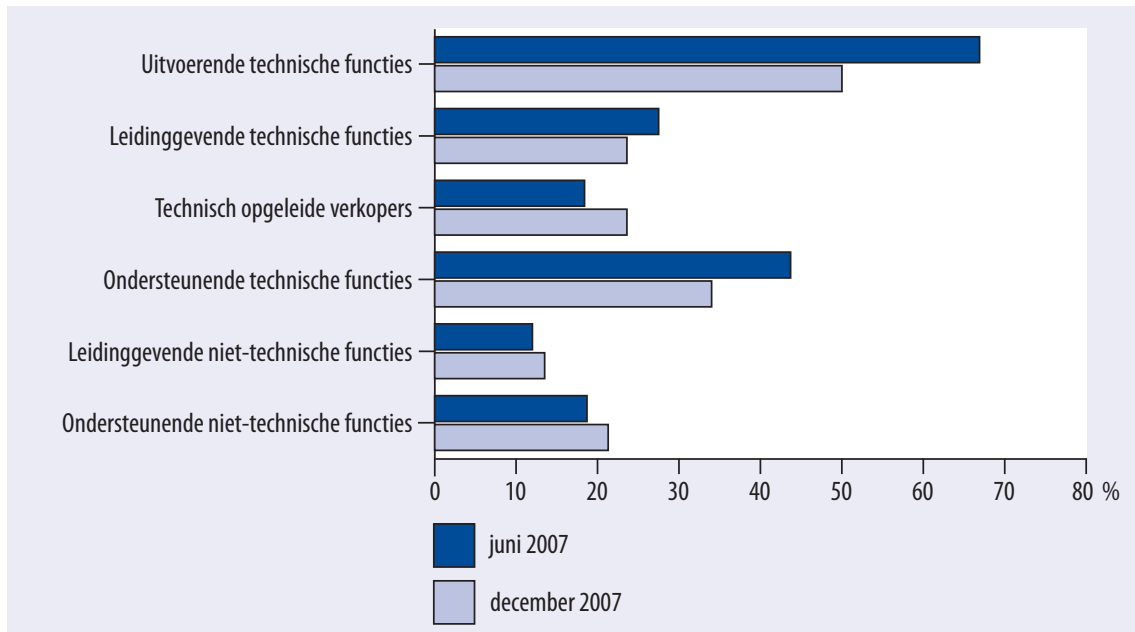

Bron: ROA / Werkgeverspanel Metalektro 2007

Tweederde van de Metalektrobedrijven had in juni 2007 openstaande vacatures voor uitvoerende technische functies. In december 2007 nam dit af tot de helft van de bedrijven. Ook voor ondersteunende technische functies hadden relatief veel bedrijven in 2007 openstaande vacatures. In juni had zo'n $45 \%$ van de bedrijven in de Metalektro openstaande vacatures voor deze functies. In december was dit nog een derde van de bedrijven. Ook bij de leidinggevende technische functies was er sprake van een (kleine) daling van het percentage bedrijven met openstaande vacatures in december ten opzichte van juni. Voor deze functiecategorie daalde het percentage bedrijven met openstaande vacatures van $28 \%$ tot $24 \%$.

Voor technisch opgeleide verkopers en de beide niet-technische functiecategorieën was er in de loop van het jaar juist een lichte stijging van het aantal bedrijven met openstaande vacatures. In juni 2007 had I8\% van de Metalektrobedrijven openstaande vacatures voor technisch opgeleide verkoopfuncties; in december 2007 nam dit toe tot $24 \%$ van de bedrijven. Voor ondersteunende en leidinggevende niet-technische functies was er weinig verschil tussen juni en december.

Figuur 3.Io laat zien dat de Metalektrobedrijven met openstaande vacatures voor uitvoerende technische functies in juni 2007 in totaal bijna 2.800 openstaande vacatures hadden voor uitvoerende technici. In december 2007 bleef dat aantal redelijk constant. De Metalektrobedrijven met openstaande ondersteunende technische functies hadden in juni 2007 in totaal 960 vacatures voor deze functies. In december 2007 nam dit af tot 730 openstaande vacatures. In juni 2007 hadden de Metalektrobedrijven 500 openstaande leidinggevende technische functies. In december waren dit er veel minder. Toen hadden de bedrijven in de Metalektro in totaal nog 200 openstaande 
vacatures voor leidinggevende technici. Het aantal openstaande vacatures voor technisch opgeleide verkopers liep in de loop van 2007 iets terug, van 350 openstaande vacatures in juni naar 290 vacatures in december.

\section{Figuur 3.10}

Aantal openstaande vacatures per functiecategorie, 2007

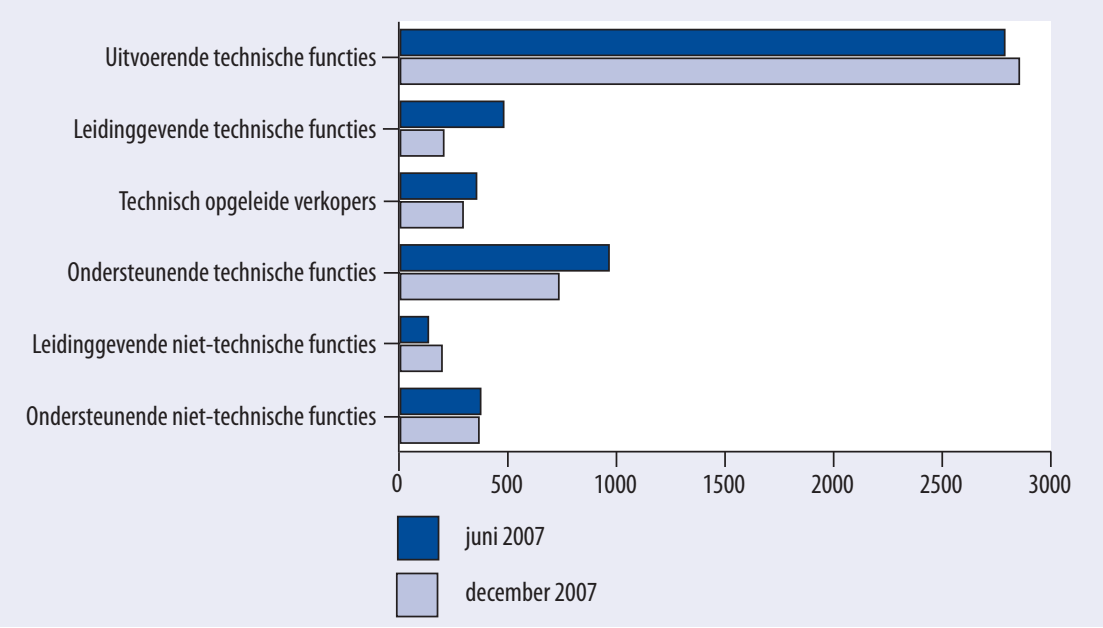

Bron: ROA / Werkgeverspanel Metalektro 2007

\section{Figuur 3.11}

Aantal openstaande vacatures voor uitvoerende technische functies, 2007

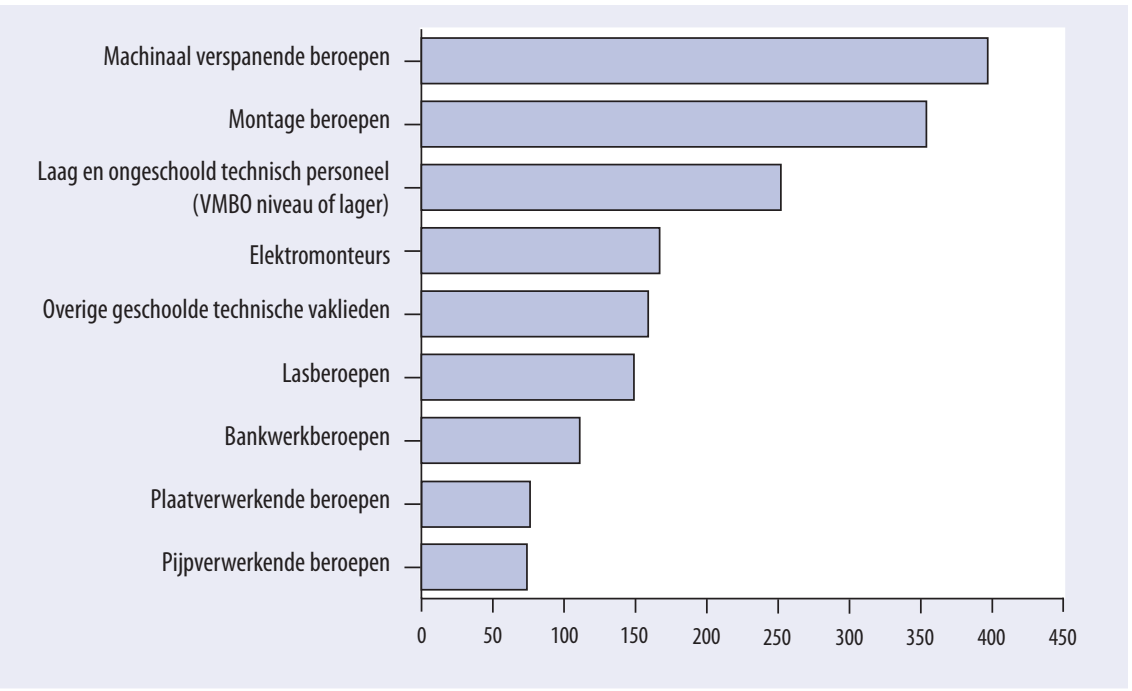

Bron: ROA / Werkgeverspanel Metalektro 2007 
Om inzicht te krijgen voor welke specifieke technische functies er vooral openstaande vacatures waren, hebben we de bedrijven in de Metalektro gevraagd om hun openstaande vacatures voor technische functies nader te specificeren. In figuur 3.II wordt weergegeven hoeveel vacatures er in verschillende uitvoerende technische functie openstaan. In figuur 3.12 wordt voor de ondersteunende technische functies weergeven hoeveel vacatures er per specifieke functie openstaan.

Figuur 3.II laat zien dat de Metalektrobedrijven de meeste openstaande vacatures hebben voor de machinaal verspanende beroepen. Daarbij gaat het om ongeveer 400 vacatures. Daarnaast zijn er 350 openstaande vacatures voor montageberoepen. Ook hebben metalektrobedrijven nog steeds openstaande vacatures voor laag dan wel ongeschoold technisch personeel: Er stonden bij de bedrijven in de Metalektro in 2007 ongeveer 250 vacatures openen voor technici die laag- of ongeschoold zijn. De Metalektrobedrijven waren in 2007 ook regelmatig op zoek naar elektromonteurs en lassers. Voor de bankwerkberoepen waren er in 2007 ruim Ioo openstaande vacatures en voor de plaatverwerkende beroepen en pijpverwerkende beroepen zo'n 75 .

\section{Figuur 3.12}

Aantal openstaande vacatures voor ondersteunende technische functies, 2007

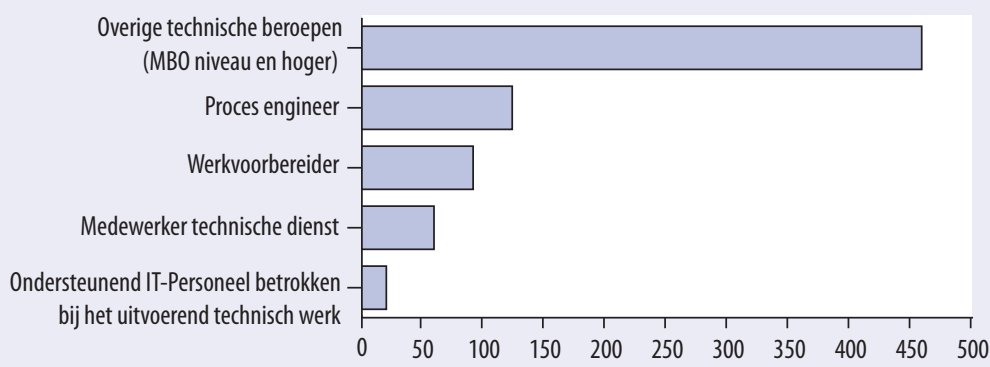

Bron: ROA / Werkgeverspanel Metalektro 2007

Zoals in figuur $3 . \mathrm{I} 2$ te zien is, stonden er bij de ondersteunende technische beroepen relatief veel vacatures open voor procesengineers (I20) en werkvoorbereiders (90). De bedrijven in de Metalektro hadden in 2007 ook nog 60 openstaande vacatures voor medewerkers technische dienst en 20 openstaande vacatures voor ondersteunend IT-personeel. Maar verreweg het grootste deel van de openstaande vacatures voor ondersteunende technische beroepen vallen binnen de categorie overige technische beroepen (MBO-niveau of hoger). Het gaat hierbij namelijk om ongeveer 450 openstaande functies.

In figuur 3.13 wordt aangegeven hoe lang de vacatures voor technisch personeel openstaan. In juni 2007 werd $53 \%$ van de openstaande vacatures binnen drie maanden vervuld. Dat is vergelijkbaar met de situatie in juni 2006. In december 2007 werden er minder vacatures binnen drie maanden vervuld. Toen werd slechts voor $46 \%$ van de vacatures binnen drie maanden geschikt personeel aangenomen. Er is vooral sprake 
van een toename van het aantal vacatures dat drie tot zes maanden open staat voor men ze kan vervullen. In juni 2006 stond nog $22 \%$ van de vacatures drie tot zes maanden open. In 2007 was dit gestegen tot $27 \%$ in juni en $28 \%$ in december.

Figuur 3.13

Percentage vacatures voor technisch personeel, naar het aantal maanden dat ze openstaan, 2007

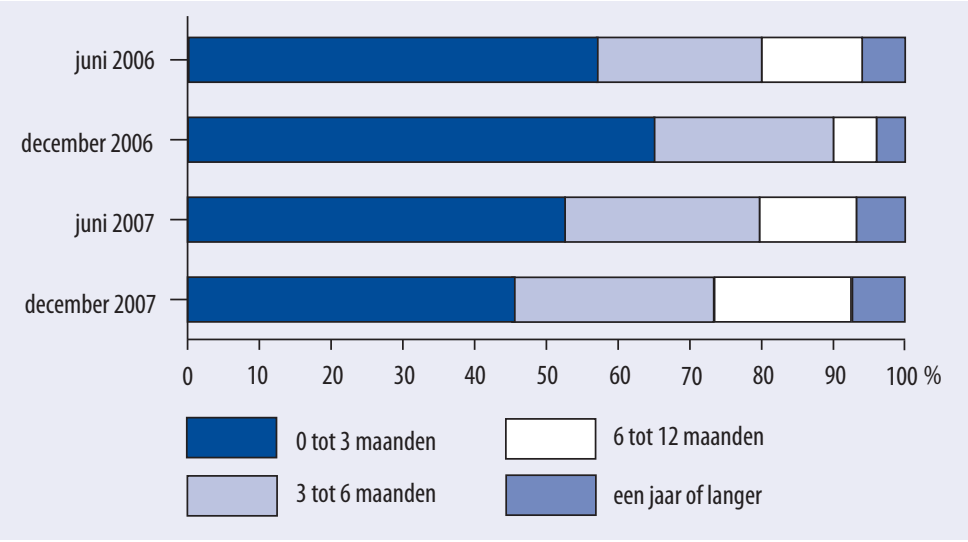

Bron: ROA / Werkgeverspanel Metalektro 2007

In figuur 3.I4 wordt de ontwikkeling van het percentage lang openstaande vacatures voor technisch personeel weergegeven. Hieruit blijkt dat er ook steeds meer vacatures erg lang blijven openstaan. In juni 2005 bleef nog $8 \%$ van de vacatures zes maanden tot een jaar openstaan, In december 2007 was dit toegenomen tot $19 \%$ van alle vacatures voor technisch personeel. Het percentage vacatures dat langer dan een jaar openstaat, is eveneens gegroeid. In december 2005 bleef er nog $2 \%$ van alle vacatures voor technisch personeel langer dan een jaar open staan; in december 2007 was dit maar liefst $7 \%$.

In figuur 3.15 worden de belangrijkste redenen voor het ontstaan van vacatures voor technisch personeel weergegeven. Maar liefst $65 \%$ van de bedrijven in de Metalektro ziet de groei van het bedrijf en/of een toename van de hoeveelheid werk als reden voor het ontstaan van vacatures voor technische medewerkers. Bij iets meer dan de helft van de bedrijven zijn vacatures het gevolg van het vrijwillige vertrek van technisch personeel. Vier van de tien bedrijven hebben te maken met openstaande vacatures naar aanleiding van personeel dat met pensioen is gegaan. Ongeveer IO\% van de bedrijven in de Metalektro zag vacatures ontstaan door interne mobiliteit en langdurige ziekte van werknemers. Andere redenen die genoemd werden waren o.a. ontslag of het aflopen van tijdelijke contracten van werknemers. 


\section{Figuur 3.14}

Ontwikkeling aandeel lang openstaande vacatures (6 maanden of langer), 2005-2007

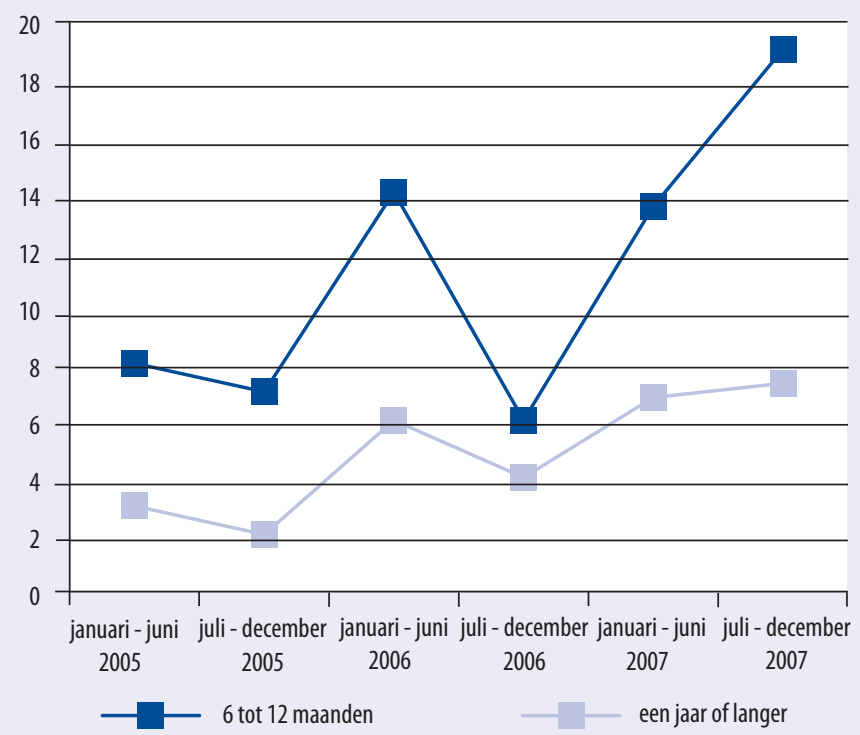

Bron: ROA / Werkgeverspanel Metalektro 2007

\section{Figuur 3.15}

Reden van ontstaan van vacatures voor technisch personeel, 2007

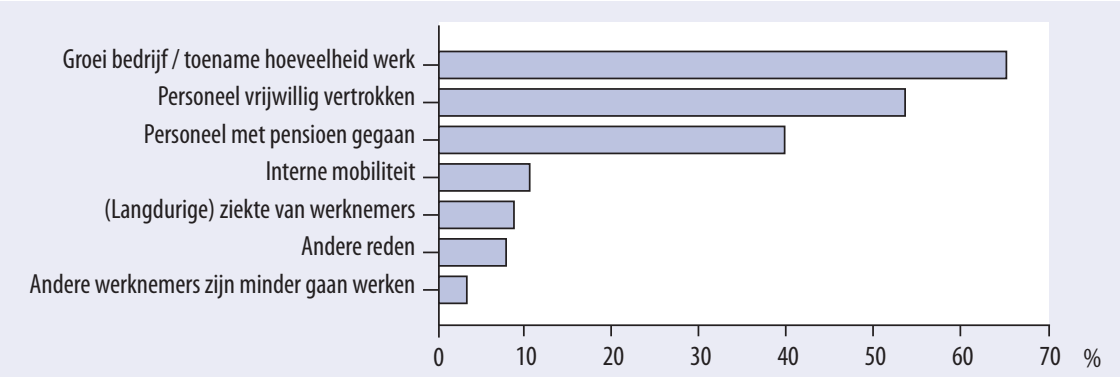

Bron: ROA / Werkgeverspanel Metalektro 2007

\section{Regionale verschillen vacatures}

In figuur 3.I6 laten wij het aandeel langdurig openstaande vacatures per regio zien. Langdurig openstaand zijn alle vacatures die langer dan 6 maanden open staan. Wij maken hierbij onderscheid tussen de regio West, Zuid, en Noord/Oost. Het laagste aandeel aan langdurig openstaande vacatures heeft de regio Noord/Oost, met I4\%. Vergelijkbaar is de regio Zuid, waar zo'n I7\% van de vacatures langer dan 6 maanden open staat. De regio West kampt met 
veel meer langdurig openstaande vacatures. Hier staan $37 \%$ van de vacatures langer dan 6 maanden uitgeschreven.

\section{Figuur 3.16}

Percentage vacatures dat langer dan 6 maanden openstaat (\% van alle vacatures), per regio, 2007

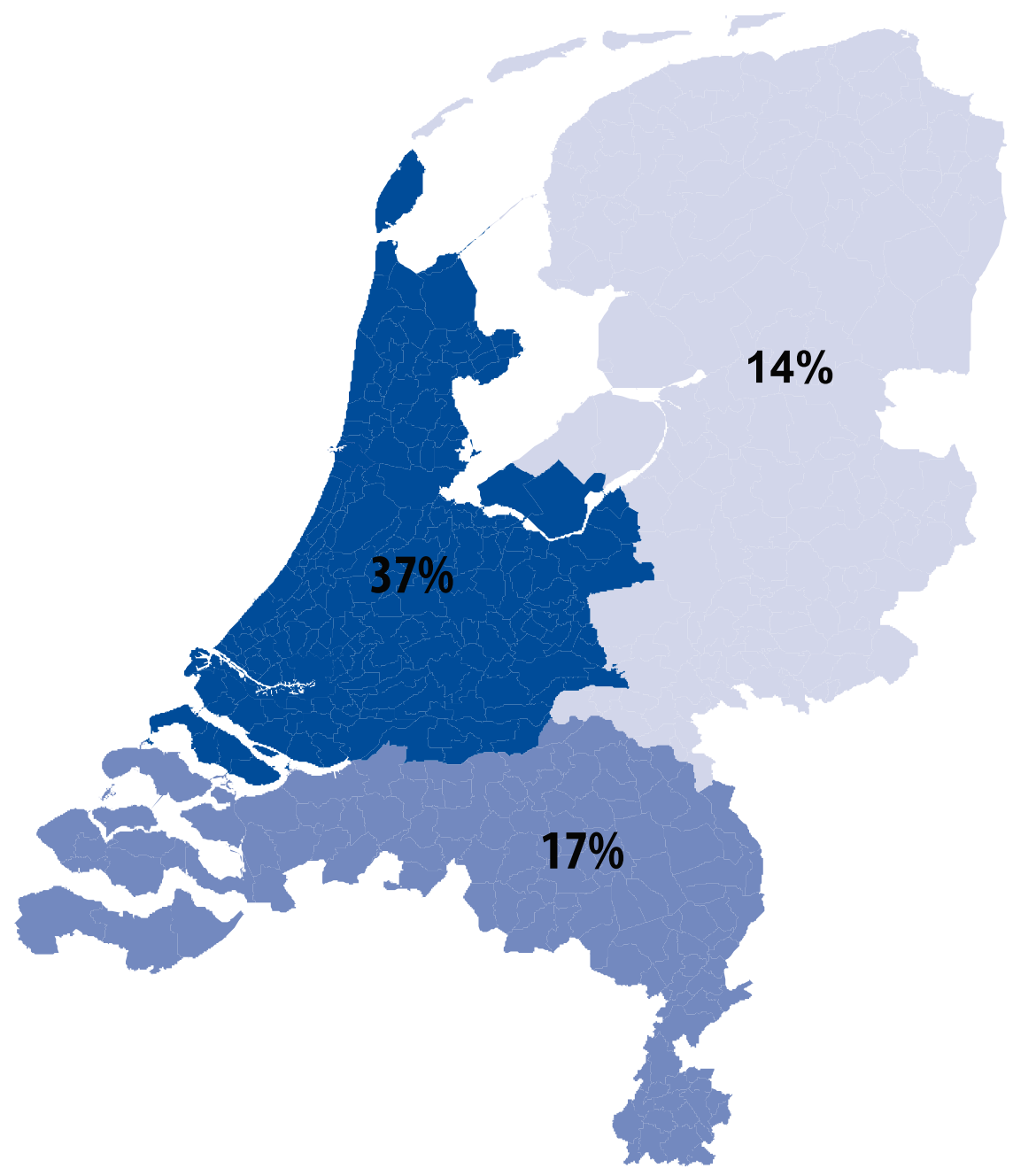

Bron: ROA / Werkgeverspanel Metalektro 2007

\subsection{Problemen bij de werving}

Zoals we al in de figuren 3.13 en 3.I4 zagen, hebben bedrijven in de Metalektro het steeds moeilijker om geschikt technisch personeel te vinden. Het lijkt er dus op dat de 
bedrijven veel problemen ervaren bij de werving van technisch personeel. Figuur 3.I7 laat zien dat steeds meer Metalektrobedrijven problemen ervaren bij de werving van technisch personeel. Vanaf 2004 daalde het percentage bedrijven dat geen wervingsproblemen heeft maar liefst van $46 \%$ tot $13 \%$. Ook het percentage bedrijven dat weinig of erg weinig wervingsproblemen heeft daalde de afgelopen jaren sterk. Daar tegenover staat een sterke groei van het percentage bedrijven dat veel of zeer veel problemen heeft met de werving van technisch personeel. De figuur laat hiermee goed zien dat steeds meer bedrijven in de Metalektro in de knel komen bij het vinden van voldoende nieuw technisch personeel.

\section{Figuur 3.17}

Ontwikkeling van het percentage bedrijven met problemen bij de werving van technisch personeel, 2002-2007

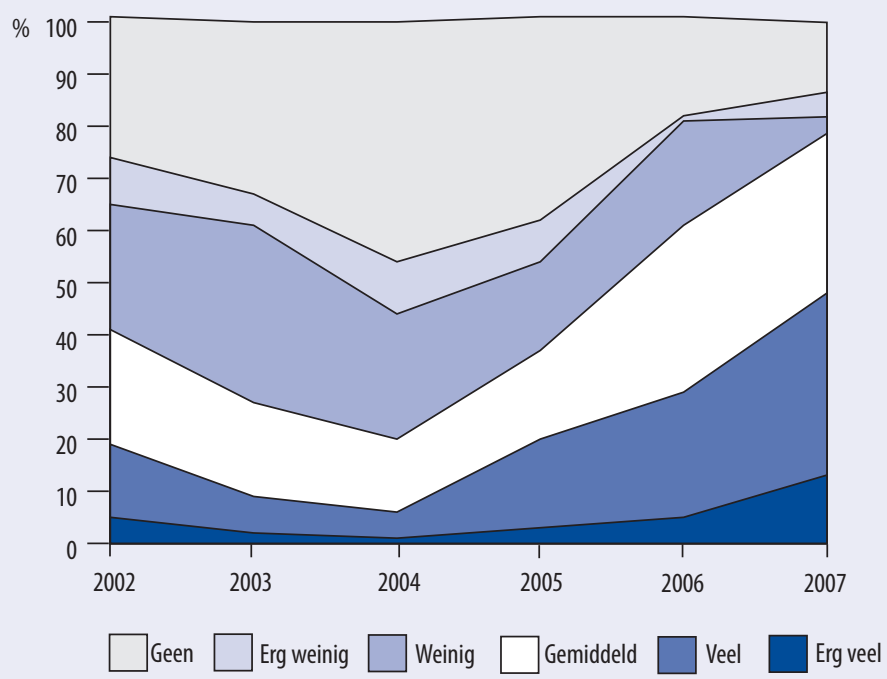

Bron: ROA / Werkgeverspanel Metalektro 2007

Figuur 3.I8 laat zien dat er bij uitvoerende technische functies het vaakst wervingsproblemen zijn. Maar liefst $77 \%$ van de bedrijven in de Metalektro had in 2007 te maken met problemen bij het vinden van geschikte uitvoerende technici. $43 \%$ van de Metalektrobedrijven ondervindt problemen bij het vervullen van vacatures voor ondersteunende technische functies en ongeveer een kwart van de bedrijven heeft problemen bij het vinden van geschikt personeel voor leidinggevende functies. Ten slotte heeft $15 \%$ van de bedrijven in de Metalektro problemen bij de werving van technisch opgeleide verkopers. 


\section{Figuur 3.18}

Percentage bedrijven dat problemen ondervindt bij het vervullen van technische functies, 2007, per functiecategorie

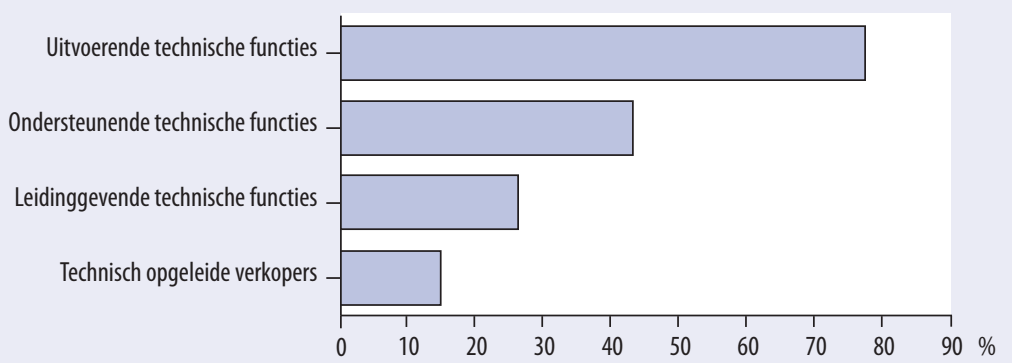

Bron: ROA / Werkgeverspanel Metalektro 2007 


\section{Competentieontwikkeling en HRM}

In dit hoofdstuk richten we ons op de competentieontwikkeling en het trainingsbeleid in de Metalektro in 2007. In paragraaf 4.I gaan we in op de algemene ontwikkelingen van het trainingsbeleid in de sector. In paragraaf 4.2 komen vervolgens de inhoud van trainingen en de competentieontwikkeling in de Metalektro aan bod, waarna we in paragraaf 4.3 ingaan op de communicatie binnen het bedrijf en de wijze waarop bedrijven hun personeel stimuleren om deel te nemen aan trainingen.

\subsection{Opleiden in de Metalektro}

De technologische innovaties en de daaraan gerelateerde sociale innovaties, leiden in veel bedrijven tot een upgrading van de voor een goede uitoefening van het werk vereiste competenties. Om de competenties van het personeel te verbeteren en up-todate te houden, zijn vaak aanzienlijke investeringen nodig in training en opleiding.

\section{Figuur 4.1}

Stelling: "Bij personeelstekorten is het scholen van het eigen personeel op de lange termijn effectiever dan het inhuren of inlenen van tijdelijke krachten", (\% bedrijven)

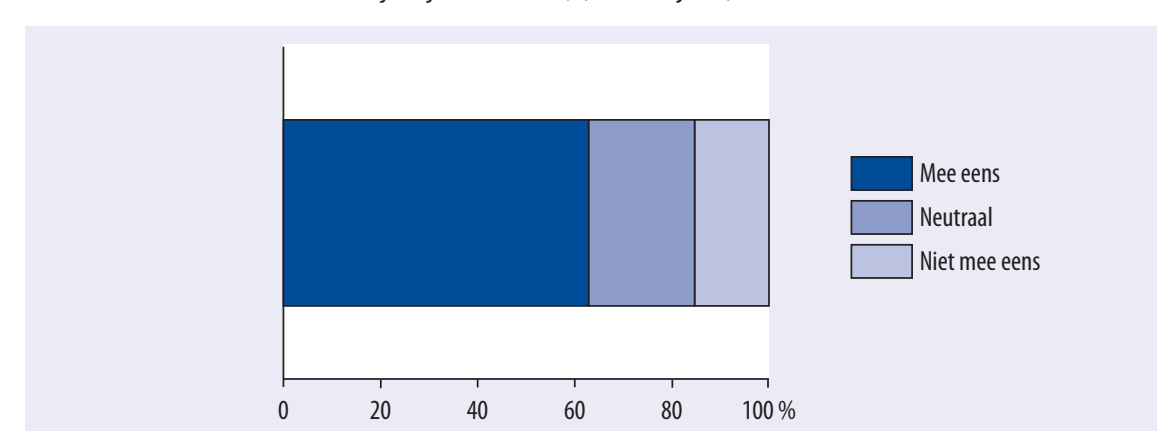

Bron: ROA, Quickscan, Oktober 2007

De investeringen in de scholing van het personeel zijn ook van groot belang voor het loopbaanbeleid van de Metalektro bedrijven en het inspelen op de verwachte personeelstekorten. Bedrijven kunnen daarbij hun eigen werknemers aanvullende scholing laten volgen om vacatures in te vullen waarvoor moeilijk personeel kan worden aangetrokken. Bijna tweederde van de bedrijven is het dan ook eens met de stelling dat bij 
personeelstekorten het scholen van het eigen personeel op de lange termijn effectiever is dan het inhuren of inlenen van tijdelijke krachten (zie figuur 4.I).

In vorige versies van de Arbeidsmarktmonitor Metalektro is al eerder geconstateerd dat veel metalektrobedrijven voorkeur geven aan het ontwikkelen van de juiste competenties onder het huidige personeel boven het aantrekken van nieuwe medewerkers, om daarmee de vereiste competenties in te kopen. Op een krappe arbeidsmarkt is dit ook de meest effectieve strategie.

$\mathrm{Na}$ een terugval van de uitgaven in het recessiejaar 2004, is er al weer enige jaren sprake van een stijgende lijn in de investeringen in trainingen en opleidingen voor het personeel. Figuur 4.2 geeft een overzicht van de ontwikkeling van de gemiddelde opleidingskosten per bedrijf. Deze kosten hebben slechts betrekking op de 'out-ofpocket' kosten; de kosten van de werktijd waarin een werknemer vanwege de training niet productief kan worden ingezet, zijn niet meegenomen.

\section{Figuur 4.2}

Ontwikkeling van de gemiddelde totale opleidingskosten per bedrijf, 2003-2007.

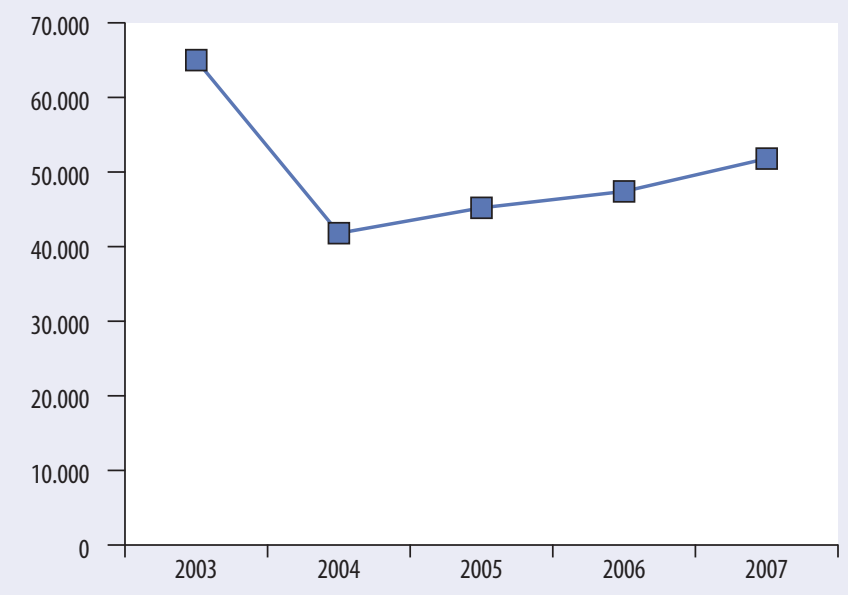

Bron: ROA / Werkgeverspanel Metalektro 2003-2007

Men moet voorzichtig zijn met het interpreteren van deze gemiddelde totale trainingsuitgaven. Zo laat figuur 4.3 zien dat het percentage medewerkers dat een externe opleiding volgde vanaf 2003 is gedaald. Ook is het percentage dat een interne training of opleiding volgde vanaf 2004 afgenomen. Wanneer we de in figuur 4.3 geschetste ontwikkeling met de in figuur 4.2 geschetste kostenontwikkeling vergelijken, dan blijkt dat het trainingsbeleid in veel Metalektro bedrijven selectiever is geworden. 
Daarbij wordt er meer geïnvesteerd in de medewerkers die worden getraind. ${ }^{\text {I }}$ De gemiddelde 'out-of-pocket' kosten per getrainde werknemer zijn in de laatste drie jaar gestegen van $€ \mathrm{I} .300$ in 2005 , via $€ \mathrm{I} .600$ in 2006 , naar $€ 2.000$ in 2007 . Wel moet opgemerkt worden dat informeel leren, zoals "training on the job" hierbij niet wordt gemeten. Het gaat hier alleen om formele trainingen en opleidingen.

\section{Figuur 4.3}

Trainings- en opleidingsdeelname in procenten van het aantal werknemers

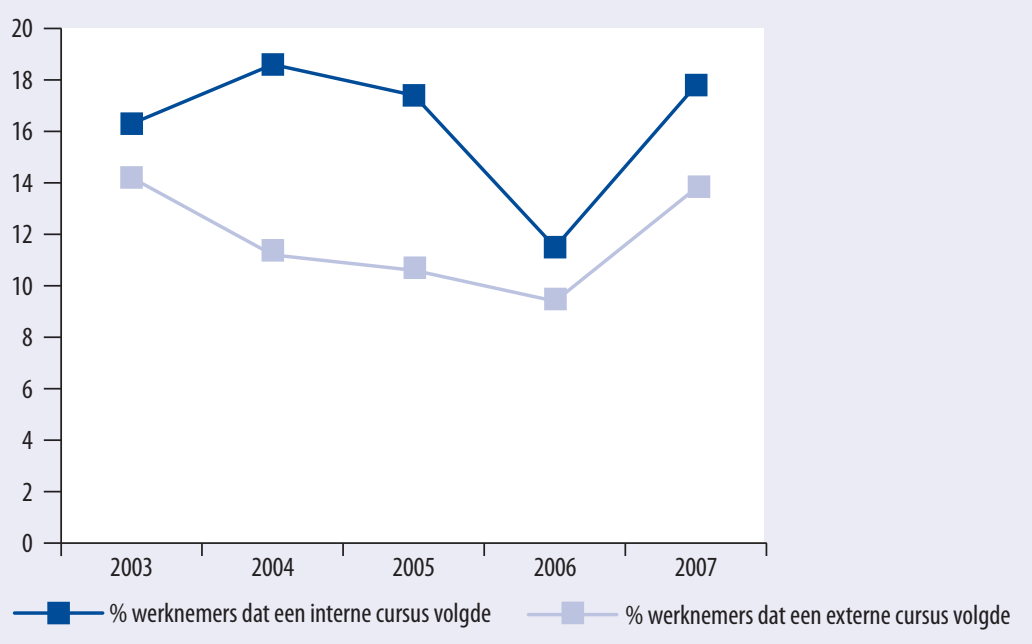

Bron: ROA / Werkgeverspanel Metalektro 2003-2007

Vanaf 2006 worden ook de indirecte kosten van trainings- en opleidingsdeelname in de arbeidsmarktmonitor gemeten. In 2006 besteedde een technisch medewerker gemiddeld 8,5 werkdagen aan opleiding en training. Dit is in 2007 gestegen naar 9 werkdagen.

Figuur 4.3 geeft de deelname in procenten van het aantal medewerkers weer. In de jaren 2003 - 2006 blijkt de trainingsdeelname te zijn teruggelopen. In 2007 is er echter weer sprake van een toename in de trainingsdeelname. In 2007 volgde bijna I $8 \%$ van de medewerkers een interne en bijna I4\% een externe cursus. Dit ligt weer ongeveer op hetzelfde niveau als in 2004.

De kosten van cursussen en trainingen worden voornamelijk door de bedrijven zelf betaald: $96 \%$ van de bedrijven betalen de trainingskosten.

I. Als bedrijven in een bepaald jaar heel veel investeren in trainingsuitgaven en vervolgens een pas op de plaats maken kan dit de gemiddelde trainingsuitgaven overigens beïnvloeden. 


\section{Belemmeringen}

Metalektrobedrijven ondervinden verschillende belemmeringen om hun technisch personeel op te leiden. Figuur 4.4 laat zien dat meer dan de helft van de bedrijven met belemmeringen te maken had bij het realiseren van hun trainingsbeleid. Dit is overigens duidelijk minder dan in 2006 toen nog $73 \%$ van de bedrijven belemmeringen ondervond.

\section{Figuur 4.4}

Belemmeringen voor de deelname aan trainingen / opleidingen, 2007 (\% bedrijven)

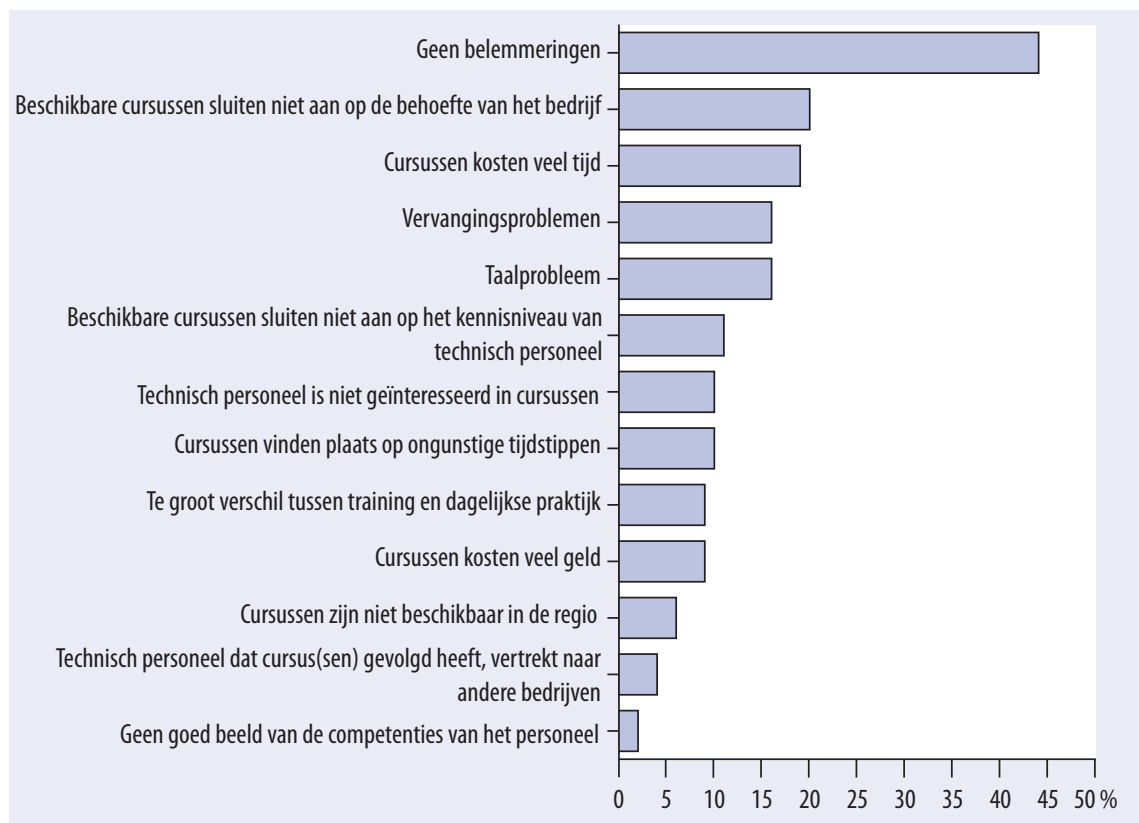

Bron: ROA / Werkgeverspanel Metalektro 2007

Vaak is het een belemmering dat de scholing van werknemers ten koste gaat van de werktijd. De afwezigheid op de werkvloer van werknemers die een opleiding volgen wordt extra gevoeld in een tijd waarin er krapte is op de arbeidsmarkt en de productie op volle toeren draait. Zo geeft bijna een vijfde van de bedrijven aan dat het volgen van cursussen veel tijd kosten, en I6\% geeft expliciet aan dat vervangingsproblemen een belemmering vormen om medewerkers scholing te laten volgen.

Een geheel andere belemmering is dat cursussen niet aansluiten op de behoefte van het bedrijf. Dit is voor $20 \%$ van de bedrijven een belemmering voor verdere scholing. Ook matchen de bestaande opleidingen niet altijd goed met de opleidingsbehoefte. Zo geeft II\% van de bedrijven aan dat de beschikbare cursussen niet aansluiten op het 
kennisniveau van het technisch personeel, terwijl $9 \%$ van de bedrijven angeeft dat cursussen niet aansluiten op de dagelijkse praktijk van het werk.

Opvallend is dat slechts $9 \%$ van de bedrijven de kosten voor cursussen als belemmering aangeeft. Dit is duidelijk lager dan in 2006 toen nog bijna $20 \%$ van de bedrijven aangaf dat dit een belemmering was voor de cursusparticipatie van hun personeel.

\subsection{Scholing en competenties}

Figuur 4.5 geeft een overzicht van de inhoud van de cursussen en trainingen die het technisch personeel in de Metalektro bedrijven volgt. Daarbij wordt een onderscheid gemaakt tussen externe en interne cursussen (donker- en lichtgrijs in de grafiek). De blauwe lijn geeft het totaalbeeld weer en de gestippelde lijn de verwachting van bedrijven over welke opleidingen meer aandacht zullen krijgen. Duidelijk is te zien dat de vaktechnische cursussen het beeld domineren. Metalektrobedrijven hechten veel belang aan het up-to-date houden van de vaktechnische competenties van hun technisch personeel. Naast deze vakinhoudelijke trainingen richten veel bedrijven zich op trainingen om leidinggevende of communicatieve vaardigheden van technici te verbeteren. De helft van de bedrijven geeft aan dat hun technisch personeel dit soort trainingen volgt.

\section{Figuur 4.5}

Inhoud van de gevolgde trainingen en cursussen, 2007 (\% bedrijven)

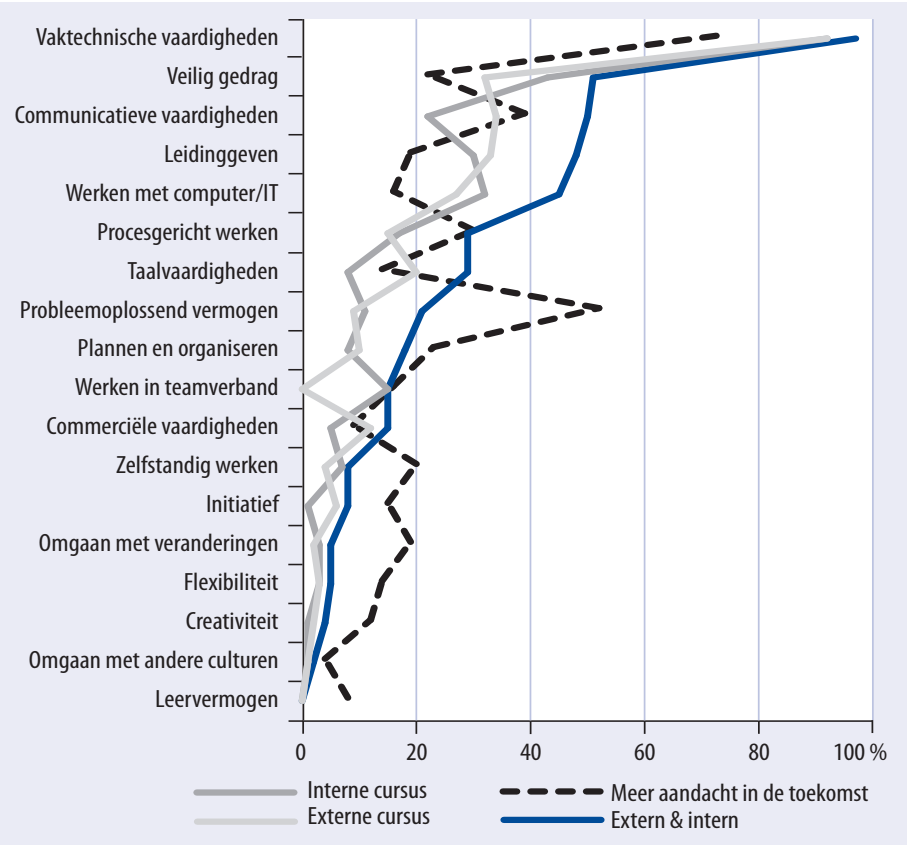

Bron: ROA / Werkgeverspanel Metalektro, 2007 
Belangrijke opleidingen zijn ook de cursussen over veilig gedrag, taalvaardigheid en het werken met IT. Veilig gedrag wordt door ruim van de helft van de bedrijven als cursus gebruikt. Bij $45 \%$ van de bedrijven komen trainingen in de IT aan bod en wordt taalvaardigheidstraining bij iets minder dan een derde van de bedrijven gevolgd.

\section{Inhoud van training}

Vaak is training gericht op het bereiken van vaktechnische competenties: "We leggen doelstellingen vast. Wat moet een persoon in een bepaalde tijd kunnen?" "Het gaat uiteindelijk om welke machines zij kunnen bedienen." "Vaktechnische competenties blijven cruciaal."

Maar er zijn ook goede ervaringen met POFI+ vaardigheden: "In mijn bedrijf werken monteurs vooral zelfstandig. Hier heeft een cursus klantgerichtheid wel degelijk goed resultaat opgeleverd." "Aan het einde van de rit moeten de werknemers zelfstandig worden."

De metalektrobedrijven verwachten dat een aantal vaardigheden in de toekomst belangrijker zal worden voor het bedrijf. Zo geeft $52 \%$ van de bedrijven aan meer aandacht te willen hebben voor trainingen die het probleemoplossend vermogen van het technisch personeel verbeteren. Ook zal er meer accent worden gelegd op cursussen voor plannen en organiseren, communicatieve vaardigheden en procesgericht werken. De meeste van deze cursussen gaan in op het zelfstandiger en met meer verantwoording te werken. Dit illustreert de upgrading van de technische functies in de Metalektro bedrijven. Door deze upgrading is er een toenemende behoefte aan technici die beschikken over goede vaktechnische competenties en de vereiste gedragscompetenties. Dit vormt ook de basis voor de POFI+ Agenda uit de vorige editie van de Arbeidsmarktmonitor Metalektro.

De metalektrobedrijven zien dat zij in de toekomst hun medewerkers nog meer moeten voorbereiden op een constant veranderende organisatie. Bijna een vijfde van de bedrijven vindt dat er meer aandacht nodig is voor cursussen die zich richten op het omgaan met veranderingen in de toekomst. Cursussen die zich richten op het bevorderen van de creativiteit en de flexibiliteit van het personeel, worden vaker aangegeven als cursussen die in de toekomst belangrijker zullen worden. In lijn met de POFI+ Agenda wiijst dit erop dat bedrijven hun werknemers willen voorbereiden op de toekomstige eisen die aan hen worden gesteld.

\subsection{Communicatie}

Veel metalektrobedrijven zijn volop aan het veranderen. Ze veranderen niet alleen hun productieprocessen of producten, maar ook hun trainings- en opleidingsbeleid. De effectiviteit van de gevolgde schooling is immers ook afhankelijk van de relatie en 
de communicatie tussen werknemers en werkgevers. Het is daarom van groot belang dat het trainingsbeleid een goed draagvlak heeft onder de werknemers.

In de Quickscan is de werkgevers van de Metalektro een stelling voorgelegd over het belang van afspraken tijdens functioneringsgesprekken over de opleiding of ontwikkeling van medewerkers. Figuur 4.6 laat zien dat veel bedrijven beseffen dat het erg belangrijk is om duidelijke afspraken te maken over de ontwikkeling van werknemers. Functioneringsgesprekken spelen ook een formele rol in de communicatie over de loopbaan en competentieontwikkeling van werknemers in relatie tot de doelen van het bedrijf. Figuur 4.7 geeft aan dat voor driekwart van de bedrijven functioneringsgesprekken een middel vormen om het belang duidelijk te maken van opleidingen en cursussen in de loopbaan en de employability van werknemers.

\section{Figuur 4.6}

Stelling: "Functioneringsgesprekken zijn een wassen neus als ze niet leiden tot afspraken over opleiding of ontwikkeling van medewerkers."

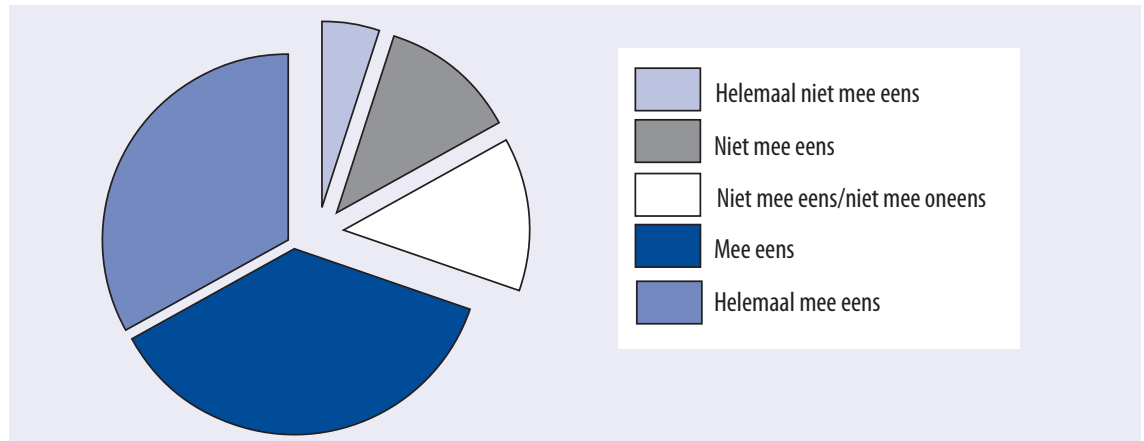

Bron: ROA / Quickscan, April 2007

Veel bedrijven proberen de leidinggevenden een actieve rol te geven om de deelname van het technisch personeel aan trainingen en opleidingen te stimuleren. Ruim een derde van de bedrijven probeert de direct leidinggevenden een coachende rol aan te leren die is gericht op de ontwikkeling van hun medewerkers. Dit is met name van belang omdat de direct leidinggevenden een grote invloed op opleidingsdeelname hebben. Tweederde van de bedrijven geeft aan dat de direct leidinggevende het initiatief neemt om het personeel deel te laten nemen aan scholing. Slechts bij I $8 \%$ van de gevolgde scholing heeft de werknemer zelf het initiatief genomen. Dit is al een aanzienlijke toename ten opzichte van 2006 . Toen werd slechts $12 \%$ van de opleidingen op initiatief van de werknemer gevolgd. Meer bedrijven zullen, gezien de toekomstige technologische veranderingen, hun werknemers moeten gaan stimuleren om zelf initiatief tot scholing te nemen.

Meer dan een vijfde van de Metalektro bedrijven probeert de belangstelling voor het volgen van trainingen bij het technische personeel te vergroten. Dit gebeurt door het 
creëren van een leerrijke werkomgeving. Ook is het belangrijk dat werknemers elkaar enthousiast maken. Een kwart van de bedrijven probeert dit te bereiken door overleg met de ondernemingsraad, de personeelsvertegenwoordiger, of door extra inspanningen van $\mathrm{P} \& \mathrm{O}$.

\section{Figuur 4.7}

Manieren waarop bedrijven de deelname van het technisch personeel aan scholing wil stimuleren (\% bedrijven)

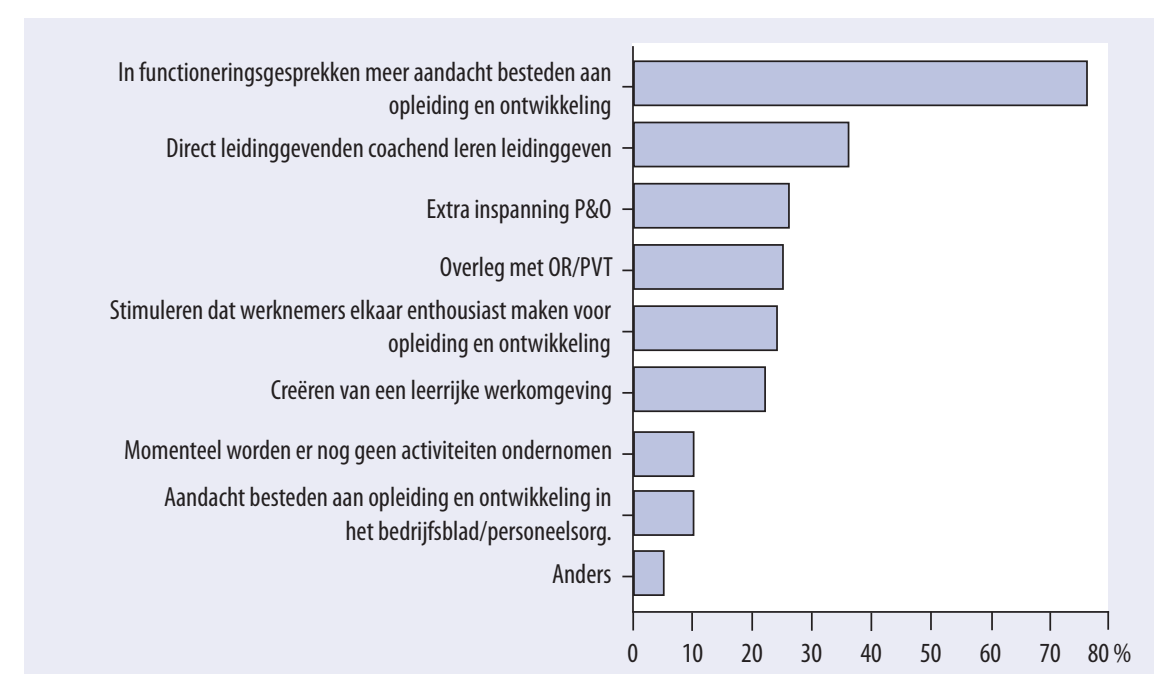

Bron: ROA / Werkgeverspanel Metalektro 2007

\section{Wie neemt het initiatief bij trainingsdeelname?}

"Het initiatief van het volgen van training is een beetje 50/50; sommige medewerkers zijn bang dat de kosten te hoog zijn en durven daarom niet om training te vragen. Sommige leidinggevenden denken dat hun medewerkers er nog niet aan toe zijn." 


\section{Loopbaanmanagement}

De vergrijzing en ontgroening van het personeel leiden binnen veel metalektrobedrijven tot discussie over loopbanen, leeftijdsbewust personeelsbeleid en de optimale inzet van de beschikbare werknemers. Het noodzaakt bedrijven tot het voeren van een goed loopbaanmanagement. Hierbij gaat het niet alleen om het zo goed mogelijk inspelen op de huidige problemen bij het aantrekken van nieuw personeel, maar vooral ook om het optimaal gebruik maken van het personeel dat al bij het bedrijf in dienst is. Bovendien moet men rekening houden met toekomstige gaten in de personeelsvoorziening als gevolg van een toenemende uitstroom vanwege pensionering. Allereerst wordt in paragraaf S.I ingegaan op de competentietekorten bij schoolverlaters. Daarna komt in paragraaf 5.2 het grote belang van zowel vaktechnische als gedragsmatige vaardigheden aan bod. Ten slotte wordt in paragraaf 5.3 ingegaan op het door de bedrijven gevoerde loopbaanbeleid en de langetermijn strategie van de metalektrobedrijven ten aanzien van de personeelsbehoefte.

\subsection{Competentietekorten bij schoolverlaters}

In de afweging tussen de inzet van ervaren of onervaren personeel, is het belangrijk om een goed beeld te hebben van de competentieverschillen tussen het jongere en oudere personeel. Door bedrijven wordt nogal eens geklaagd over de afnemende vakkennis van jonge, onervaren technici. Terwijl jonge werknemers vaak wel de juiste werkhouding hebben, kunnen zij op het moment dat ze instromen op de arbeidsmarkt niet altijd volwaardig functioneren. In de vorige editie van de Arbeidsmarktmonitor Metalektro is uitvoerig onderzocht welke competenties de werkgevers misten bij nieuwe werknemers zonder werkervaring (zie Arbeidsmarktmonitor Metalektro. Editie 2007, hoofdstuk 5). Daarbij werd door veel bedrijven voornamelijk het tekort aan vaktechnische vaardigheden genoemd. Vaak werden ook tekorten aan vaardigheden genoemd zoals probleemoplossend vermogen, zelfstandig werken en communiceren. In de door ons gevoerde gesprekken met bedrijven wordt de relevantie van deze bevindingen nog steeds bevestigd.

Werkgevers zijn, zoals gezegd, over het algemeen niet tevreden over de huidige schoolverlaters. Veel bedrijven vinden dat zij zelf het werk van de scholen opknappen. Dit kan veroorzaakt worden door het minder sterke accent op vaktechnische kennis in de initiële beroepsopleidingen, maar natuurlijk ook aan het gebrek aan ervaring. Hoe dan ook, het betekent dat een goed loopbaanmanagement reeds bij de intrede van 
een schoolverlater in het bedrijf begint. Het is immers evident dat deze nieuwe werknemers nog bepaalde vaardigheden moeten leren en ervaringen op moeten doen om optimaal te kunnen functioneren.

\section{Afstand tussen praktijk en onderwijs is te groot}

Wat veel bedrijven zorgen baart, is de afname van vaktechnische kennis. Waar soms nog voorzichtig wordt geformuleerd dat "de afstand tussen onderwijs en praktijk te groot is," spreken andere personeelsfunctionarissen duidelijker hun ongenoegen uit: "Het onderwijs in Nederland is helemaal failliet", en "al dat sociale geneuzel, ze moeten gewoon goed leren werken." Maar daarmee wordt niet de werkmoraal van de leerlingen bedoeld:"De jongelui zijn wel gemotiveerd, maar ze geven zelf aan dat ze zwemmen in het onderwijs." Bedrijven uit de grensregio's spreken ook over hun ervaringen met buitenlandse opleidingsinstellingen:"Technici die in België opgeleid zijn, hebben wel de vaktechnische competenties, waarom hebben degenen met een Nederlandse opleiding dit niet?"

In dit verband is het goed om te beseffen dat innovaties van het productieproces in veel bedrijven in de loop der jaren hebben geleid tot vernieuwingen in de organisatie van het werk die gerelaterd zijn aan 'lean production', teamwork en andere sociale innovaties. Veel productieprocessen vereisen nu dat werknemers niet alleen over voldoende vaktechnische kennis en vaardigheden moeten beschikken, maar ook over goede gedragsmatige vaardigheden. Bovendien vereist de grote technologische en organisatorische dynamiek in veel bedrijven dat de initiële opleiding een goede basis moet bieden om door te kunnen groeien in het eigen vakgebied. Ook moet het vakmensen in staat stellen om mee te kunnen laten groeien met veranderende competentieprofielen. Bij een gelijk blijvende opleidingsduur betekent dit vaak dat schoolverlaters niet direct volledig inzetbaar zijn. Schoolverlaters kampen daardoor vaak met aansluitingsproblemen tussen hun opleidingsachtergrond en de eisen die hun functie stelt.

Een goed loopbaanmanagement is dan ook cruciaal voor het optimaal inzetbaar maken van jonge medewerkers. Bedrijven zorgen er op die manier zelf voor dat cruciale vaardigheden geleerd worden, en dat de werknemer in de verschillende werkzaamheden, functies, en verantwoordingen groeit. Bovendien kan men jongeren op deze manier een goed loopbaanperspectief bieden. Wanneer de technische functies in de Metalektro op dit punt beter kunnen concurreren met economisch-administratieve functies, zal dit ongetwijfeld de aantrekkingskracht van de sector voor talentrijke jongeren met loopbaanambities vergroten.

\subsection{Vaktechnische en POFI+ vaardigheden}

De trend dat personeel zowel vaktechnische competenties als gedragsmatige competenties moet bezitten, is al langer in de Arbeidsmarktmonitor Metalektro terug te vinden (zie ook paragraaf 8.3). Het toenemende belang van deze gedragsmatige competenties, 
ofwel "soft skills", betekent echter niet dat het belang van vaktechnische kennis minder wordt. Zoals in hoofdstuk 4 over het trainings- en opleidingsbeleid van bedrijven te zien was, is de meeste training nog steeds gericht op het verbreden van vaktechnische competenties. Volgens veel bedrijven zal ook in de toekomst een groot deel van de trainingen en opleidingen gericht zijn op vaktechnische competenties.

De toegenomen vraag naar gedragsmatige competenties is daarom eerder complementair aan de behoefte aan vaktechnische competenties. Naast de vaktechnische kennis beschikt de ideale werknemer ook over de competenties die voor de modernere werkvormen belangrijk zijn. In de Editie 2007 van de arbeidsmarktmonitor werd dit aangeduid als de POFI+ agenda. Deze agenda is gericht op het verbeteren van vijf sleutelcompetenties:

- Probleemoplossend vermogen;

- Omgaan met veranderingen;

- Omgaan met klanten;

- Flexibiliteit;

- Initiatief.

Interessant is ook dat veel bedrijven op het eerste gezicht tegenstrijdige competenties verlangen, zoals het vermogen om zelfstandig, maar ook in teamverband te kunnen werken. Dit betekent niet dat technici afhankelijk van de situatie zowel zelfstandig als in teamverband moeten kunnen werken. Zelfs binnen een team kan het werken in teamverband samengaan met zelfstandig werken. Werknemers zijn binnen het team immers vaak verantwoordelijk voor verschillende werkzaamheden, die zij zelfstandig moeten oplossen. Het werken in teams vereist echter ook een goede communicatie, oog voor elkaar, en een gezamenlijk probleemoplossend vermogen.

\subsection{Loopbaanbeleid}

\section{Omvang van de interne mobiliteit}

Om een goed loopbaanbeleid te kunnen voeren is het van groot belang dat er voldoende mogelijkheden zijn om intern door te stromen naar hogere functies en/of andere functies op hetzelfde niveau. In de metalektrobedrijven is deze interne mobiliteit onveranderd hoog. Zoals uit figuur 5.I blijkt, geeft meer dan de helft van de bedrijven aan dat technici zijn doorgestroomd naar andere functies. Het merendeel van deze doorstroom is naar andere technische functies. 


\section{Figuur 5.1}

Doorstroom van technici naar technische en niet-technische functies, 2007 (\% bedrijven)

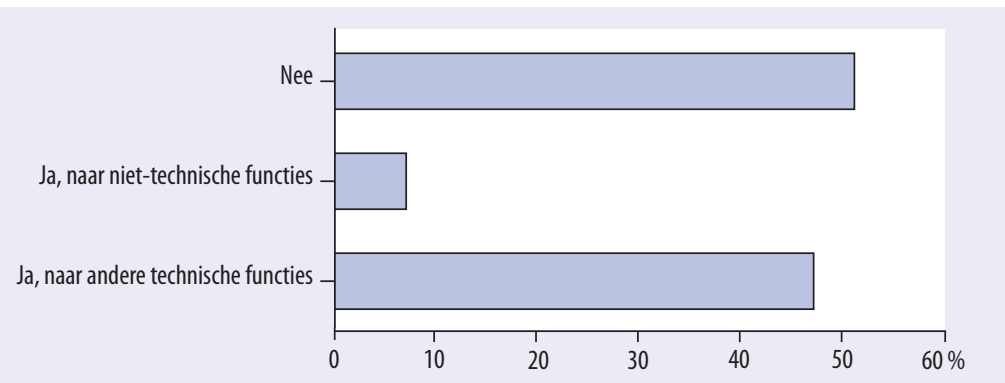

Bron: ROA / Werkgeverspanel Metalektro 2007

Figuur 5.2 laat zien welke richting deze functieverandering van technici heeft: een promotie naar een hoger niveau, laterale functieverandering of een beweging naar een lagere functie. Ruim 80\% van deze bedrijven geeft aan dat er in 2007 technici zijn doorgestroomd naar een hogere technische functie. Dit is zelfs meer dan in 2006. Toen gaf $75 \%$ van de bedrijven aan dat er in hun bedrijf sprake was van doorstroom naar hogere functieniveaus. Daarentegen is de doorstroom naar hogere niet-technische functies duidelijk afgenomen in 2007. Iets meer dan de helft van de bedrijven geeft aan dat er in hun bedrijf promoties naar niet-technische functies hebben plaatsgevonden; in 2006 was dat nog bij driekwart van de bedrijven het geval. Ook blijkt de horizontale mobiliteit naar andere technische functies op hetzelfde niveau te zijn afgenomen. Daarentegen is de horizontale mobiliteit naar niet-technische functies iets toegenomen. Neerwaartse functiemobiliteit 'demotie' komt vrijwel niet voor.

\section{Figuur 5.2}

Verticale interne functiemobiliteit van technici, 2007, (\% bedrijven)

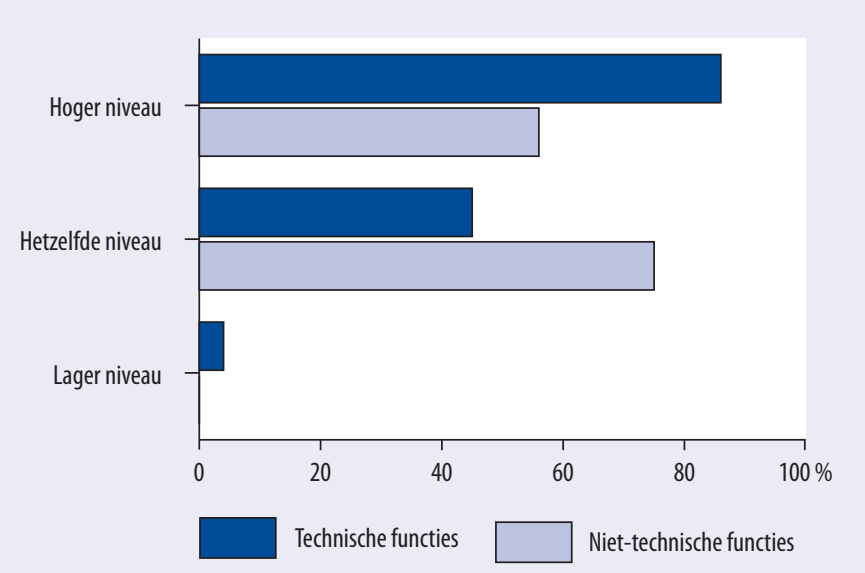

Bron: ROA / Werkgeverspanel Metalektro 2007 
In de praktijk zijn de omvang en de richting van de interne mobiliteit sterk gerelateerd aan de ontwikkelingen op de arbeidsmarkt voor technici. Neerwaartse mobiliteit zal altijd tot een hogere uitstroom van medewerkers leiden. Dit wordt in tijden van krapte op de arbeidsmarkt voor technisch personeel zo veel mogelijk vermeden. Ook wordt bij een krappe arbeidsmarkt de druk groter om door te kunnen groeien naar hogere functies. Indien een bedrijf onvoldoende kansen biedt voor de loopbaanstappen die medewerkers ambiëren, zullen medewerkers sneller overstappen naar andere bedrijven waar zij wel een hogere functie kunnen krijgen. Dit patroon is in hoofdstuk 3 terug te vinden in de genoemde redenen voor uitstroom van personeel (figuur 3.2). Ook uit het onderzoek naar de tevredenheid van werknemers in de Metalektro, kan veel van de mobiliteit worden verklaard met onvrede over de ontwikkelingsmogelijkheden, of met het krijgen van een "betere aanbieding".

Bedrijven voelen vooral bij een krappe arbeidsmarkt de druk om in hun loopbaanbeleid een attractieve werkgever te zijn. Interne mobiliteit heeft echter ook een belangrijke positieve functie voor de bedrijven zelf. Door het opleiden en laten doorstromen van het eigen personeel kan een bedrijf leidinggevende technici krijgen die bekend zijn met het bedrijf en zijn technologie. Op deze manier is het bovendien mogelijk om een goed beeld te krijgen van het functioneren van het personeel dat in de hogere functies wordt aangesteld. Men kan zo makkelijker de geschikte kandidaten op de juiste plekken te zetten. Ten slotte heeft een intern promotiebeleid ook een motiverend karakter: een promotie naar een hogere positie kan ook worden gezien als een waardering voor de kwaliteit en de inzet van de medewerker.

Horizontale mobiliteit van werknemers maar ook brede inzetbaarheid wordt vaak gebruikt om werknemers toch enige afwisseling te kunnen bieden in hun werk die niet in staat zijn om door te groeien naar hogere functies. Ook kan horizontale mobiliteit vooruitlopen op een toekomstige promotie naar een hogere functie. Door in verschillende functies te hebben gewerkt, kent een werknemer immers meer aspecten van het werk binnen het bedrijf.

\section{Tevredenheid met de mobiliteit}

Over het algemeen zijn de metalektrobedrijven tevreden over de omvang van de interne mobiliteit binnen hun bedrijf. Figuur 5.3 geeft aan dat $86 \%$ van de bedrijven tevreden is met de omvang van de interne mobiliteit, terwijl $13 \%$ de doorstroom te laag vindt. Slechts $2 \%$ vindt de interne mobiliteit in hun bedrijf te hoog. Het percentage bedrijven dat tevreden is met de interne doorstroom van hun technisch personeel ligt duidelijk hoger dan in 2006 . Toen gaven veel meer bedrijven (20\%) aan dat ze de interne doorstroom in hun bedrijf te laag vonden.

I. Th. Mos en I. de Vries, Werken in de Metalektro - Dynamiek op de Arbeidsmarkt, Dijk I2, Amsterdam, 2007 
Een te lage doorstroom kan verschillende oorzaken hebben. Het grootste probleem is meestal het beperkte aantal functies op een hoger niveau. Dit stelt automatisch een grens aan het aantal medewerkers dat naar dit niveau gepromoveerd kan worden. Alleen als er functies op dit hogere niveau vrijkomen, of als het bedrijf groeit zijn er mogelijkheden om geschikte medewerkers door te laten stromen naar dit hogere niveau.

\section{Figuur 5.3}

Tevredenheid van de bedrijven met de omvang van de interne mobiliteit van hun technisch personeel, 2007 (\% bedrijven)

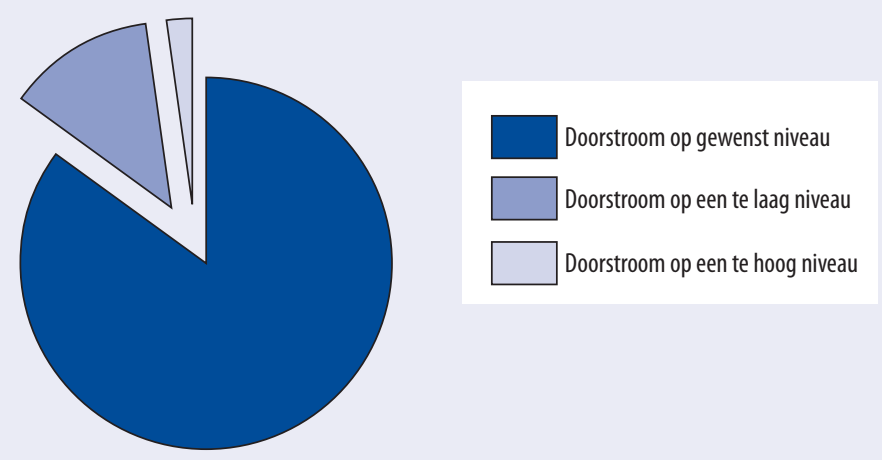

Bron: ROA / Werkgeverspanel Metalektro 207

Een andere oorzaak van een te lage doorstroom is het te lage kennisniveau van het eigen personeel. Men kan dan niet altijd de openvallende en functies invullen met eigen personeel. De oplossing hiervoor kan zijn om medewerkers intern op te leiden en zo het kennisniveau van de interne kandidaten te verhogen. Dit is echter ook afhankelijk van de kwaliteit van de interne pool van kandidaten en de kosten die deze loopbaangerichte scholing met zich mee brengt.

\section{Lange termijn strategie met betrekking tot de personeelsbehoefte}

Het uitdragen van het loopbaanbeleid maakt het voor een bedrijf gemakkelijker om zowel intern als extern duidelijk te maken dat het bedrijf een actieve rol speelt in het creëren van kansen voor zijn medewerkers. Daardoor krijgen zij de kans om een loopbaan binnen het bedrijf op te bouwen. Dit heeft twee effecten. Ten eerste kunnen bedrijven op deze manier medewerkers aan zich binden. Dit is niet alleen een belangrijk element in tijden van schaarste. Ook in tijden dat nieuwe technici makkelijk te vinden zijn, is het verlies van ambitieus personeel vaak kostbaar, omdat er vervanging moet worden gevonden. Bovendien zijn het vaak ook de beste mensen die vertrekken, omdat zij het eerst elders aanbiedingen krijgen. Het tweede effect van loopbaanbeleid en -planning is dat de werkgever attractiever wordt voor potentiële werknemers. 
Hierdoor wordt het niet alleen gemakkelijker om vacatures in te vullen, maar ook om als bedrijf aantrekkelijker te worden voor talentrijke kandidaten.

Om goed op de toekomstige personeelsbehoefte in te kunnen spelen, is het belangrijk om op dit punt een goede lange-termijn strategie te hebben. Veel bedrijven geven ook aan dat een lange-termijn strategie voor het invullen van de personeelsbehoefte wenselijk zou zijn. Lang niet alle bedrijven slagen er echter in om dit te realiseren.

\section{Figuur 5.4}

Reden voor het ontbreken van een lange-termijn strategie om te voorzien in de personeelsbehoefte (\% bedrijven)

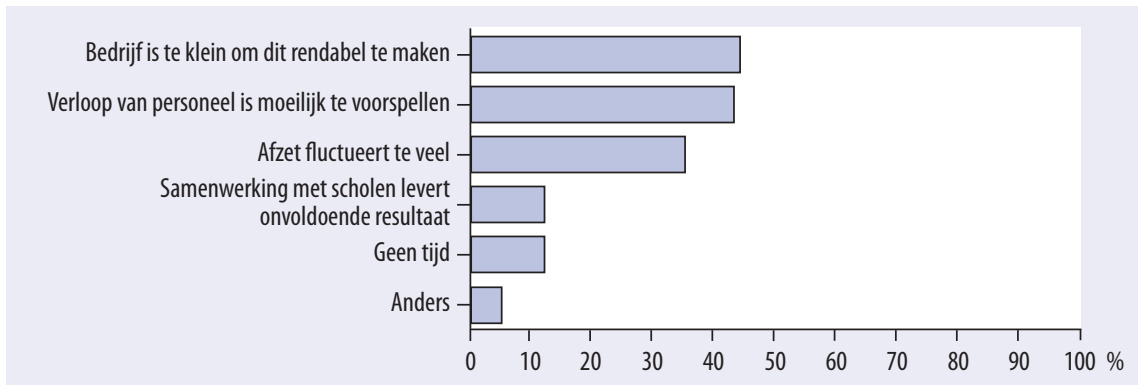

Bron: ROA / Werkgeverspanel Metalektro 2007

De belangrijkste reden om geen lange-termijn strategie te volgen, is dat dit vanwege de omvang van het bedrijf niet goed mogelijk is. Meer dan $40 \%$ van de bedrijven die geen lange-termijnstrategie heeft, geeft deze reden aan (zie figuur 5.4). Een andere belangrijke reden die een lange-termijn strategie moeilijk makt, is dat belangrijke factoren voor het bedrijf moeilijk te voorspellen zijn. Deze onvoorspelbaarheid heeft ook betrekking op de ontwikkeling van de afzet van het bedrijf. Dit geldt vooral voor bedrijven waar sterke fluctuaties in de afzet tot grote schommelingen in de personeelsbehoefte leiden. Ook kan het zijn dat het personeelsverloop moeilijk te voorspellen is. Juist de kleinere bedrijven zullen hier last van hebben, omdat hier het verlies van een handvol medewerkers al tot grote problemen kan leiden.

Figuur 5.5 geeft aan dat de meeste bedrijven met een lange-termijn strategie om te voorzien in hun personeelsbehoefte, zich richten op het krijgen van een goed beeld van het verwachte personeelsverloop in de komende jaren. Meer dan $80 \%$ van de bedrijven geeft aan dit te doen. Vervolgens is het van belang om een goede strategie te ontwikkelen om het verwachte verloop op te vangen. Hier worden verschillende combinaties van strategieën ingezet. Bijna $60 \%$ van de bedrijven combineert een lange-termijn planning voor de structurele ontwikkeling met het aantrekken van inhuurkrachten voor het opvangen van piekbelastingen. Ruim de helft van de bedrijven probeert via hun trainingsbeleid het huidige personeel op te leiden voor toekomstige vacatures. Bijna de helft van de bedrijven zoekt samenwerking met scholen om de toekomstige instroom van schoolverlaters op peil te houden of te vergroten en ruim $15 \%$ van de 
bedrijven probeert door samenwerking met andere bedrijven in de regio nieuw personeel aan te trekken.

\section{Figuur 5.5}

Inhoud van lange-termijn strategieën om te voorzien in de personeelsbehoefte (\% bedrijven)

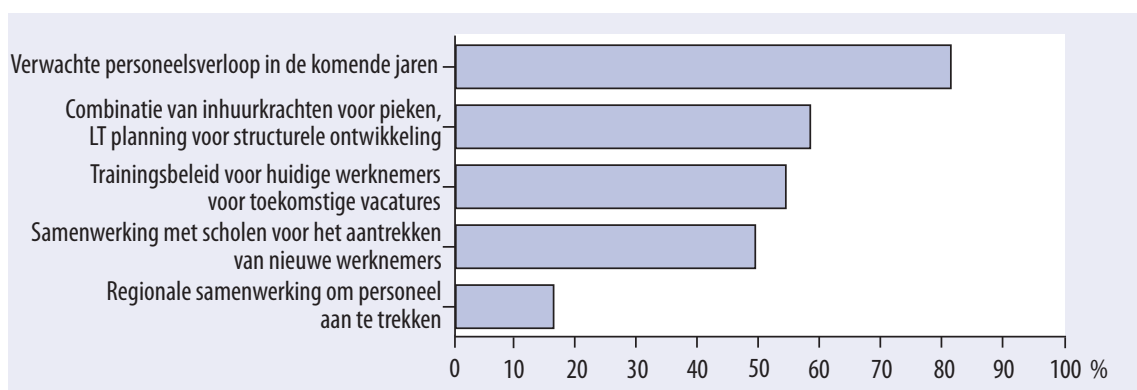

Bron: ROA / Werkgeverspanel Metalektro 2007

\section{Samenwerking met het onderwijs}

Bedrijven klagen veelal over de samenwerking met scholen. De contactpersonen wisselen, exameneisen zijn onduidelijk, en vaak moeten de bedrijven het contact onderhouden: "kk heb een beetje moeite met de scholen. Het is absoluut niet duidelijk wie aanspreekpartner is." Bedrijven met positieve ervaringen schrijven dit vaak toe aan het initiatief van de contactpersoon of leraar: "Je moet geluk hebben dat je een leraar hebt, die ervoor gaat." Het formeel vastleggen van de afspraken met een school, zorgt vaak voor goede ervaringen: "Je moet ook hier gewoon alles goed en duidelijk vastleggen in een contract, daar hebben wij goede ervaringen mee."

Vaak worden contacten met scholen niet alleen onderhouden om naamsbekendheid op te bouwen, maar ook om het imago van de sector te verbeteren: "Wij laten kleinere projecten zelf op school uitvoeren, zo komen de leerlingen automatisch in contact met ons werk". Een HRM manager vat dit dan ook samen als "een stukje maatschappelijke verantwoordelijkheid." 


\section{Sociale innovatie}

In dit hoofdstuk gaan we dieper in op de sociale innovatie in de Metalektro. Paragraaf 6.I beschrijft de relatie tussen sociale en technologische innovaties binnen de Metalektro. Hierbij wordt ingegaan op de aard van de sociale innovaties en de doelstellingen die bedrijven hiermee trachten te bereiken. In paragraaf 6.2 komt de brede inzetbaarheid van het personeel aan bod. Daarbij wordt zowel ingegaan op de behoefte aan breed inzetbaar personeel als op de daadwerkelijke brede inzetbaarheid van het personeel.

\subsection{Sociale innovatie in de Metalektro}

\section{Relatie tussen sociale en technologische innovatie}

Technologische innovaties zijn voor de meeste bedrijven vaak gemakkelijk te definieren. Het gaat dan altijd om het vernieuwen van de producten die het bedrijf voortbrengt, of het vernieuwen van het productieproces. Veel metalektrobedrijven beseffen dat het voor hen cruciaal is om zich naast deze technologische innovaties ook op sociale innovatie te richten. Sociale innovatie werd door de SER gedefinieerd als "het vernieuwen van de arbeidsorganisatie en het maximaal benutten van de competenties van het personeel, gericht op de verbetering van de bedrijfsprestaties en de ontplooiing van talent". ${ }^{\prime}$

De noodzaak tot sociale innovatie ligt vaak in het verlengde van technologische vernieuwingen in het productieproces en de noodzaak om producten van hoogwaardige kwaliteit te leveren en de behoefte van bedrijven om beter en flexibeler in te kunnen spelen op specifieke wensen van afnemers. Sociale innovatie raakt daarmee andere thema's die in dit rapport de revue zijn gepasseerd, zoals de inzetbaarheid en de competenties van het personeel en het verder ontwikkelen van het HRM beleid.

Zoals figuur 6.I laat zien is de meerderheid van de bedrijven het eens met de stelling dat bij product- en procesinnovaties de gevolgen voor het personeel vroegtijdig moeten worden meegenomen. Veel bedrijven lijken zich ook bewust te zijn van de complementariteit van technologische en sociale innovaties.

I. SER, Welvaartsgroei door en voor iedereen. Thema sociale innovatie. Advies 06/o8, Den Haag 2006. 


\section{Figuur 6.1}

Product- en procesinnovatie en sociale innovatie (\% bedrijven)

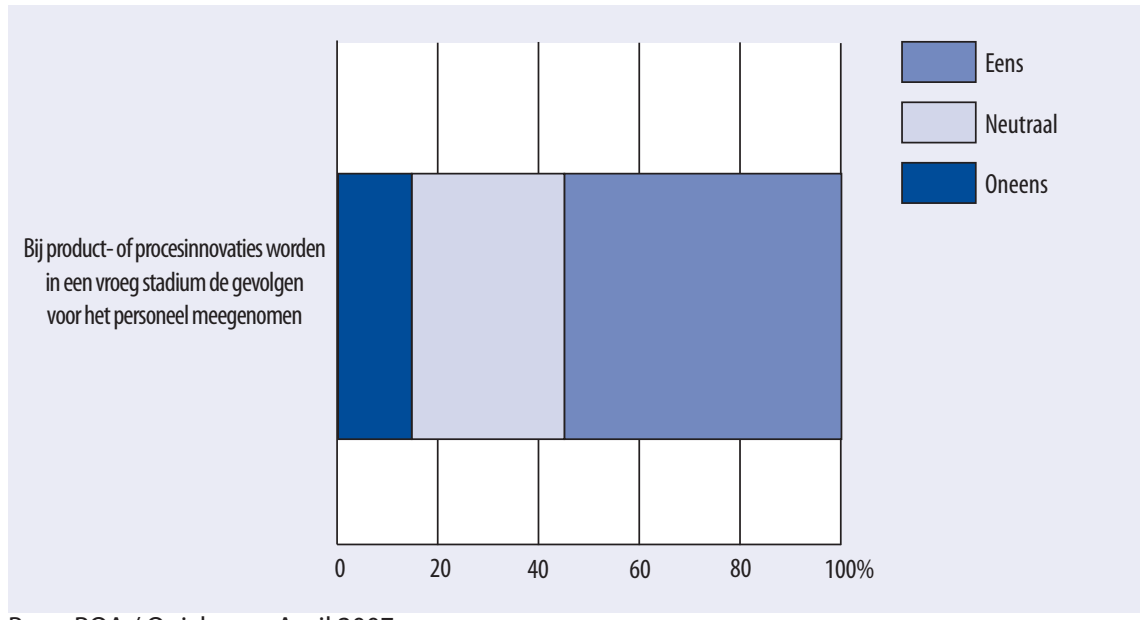

Bron: ROA / Quickscan, April 2007

Figuur 6.2 legt een relatie tussen technologische en sociale innovatie. Metalektrobedrijven die organisatorische vernieuwingen plannen, verwachten ook veel vaker technologische innovaties: Meer dan $80 \%$ van de bedrijven geeft aan dat zij het komende jaar een organisatieverandering gaan doorvoeren die als een sociale innovatie kan worden gezien. Bij 70\% van deze bedrijven vinden er ook technologische innovaties plaats. Van de bedrijven die het komende jaar geen sociale innovaties doorvoeren, verwacht daarentegen slechts $38 \%$ technologische product- of procesinnovaties door te voeren. Als we kijken naar de bedrijven die op middellange termijn sociale innovaties willen doorvoeren, zien we dezelfde relatie.

\section{Figuur 6.2}

De relatie tussen sociale innovatie en technologische innovatie (\% bedrijven)

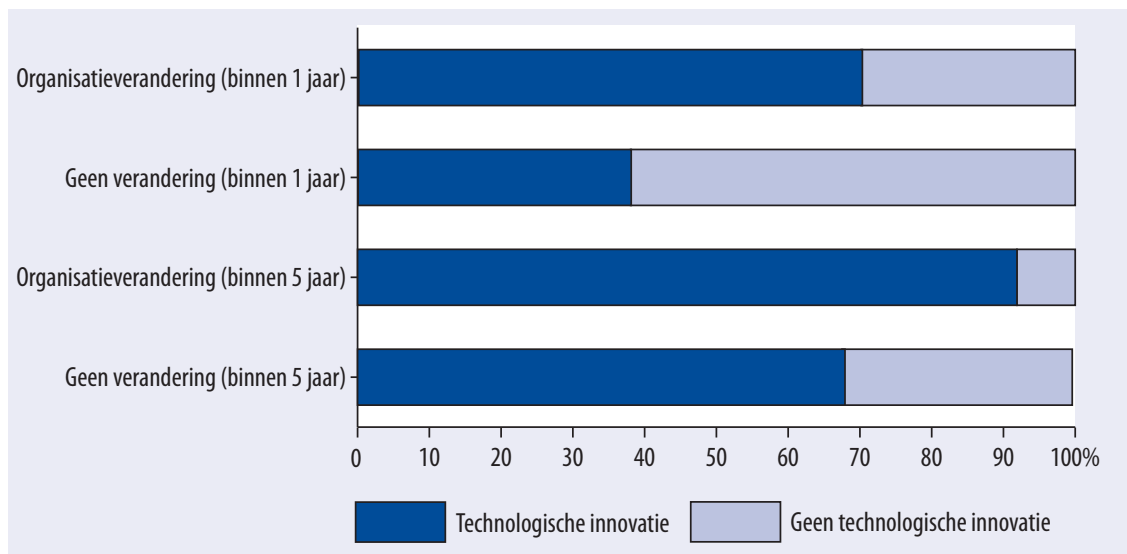

Bron: ROA / Werkgeverspanel Metalektro 2007 


\section{Vormen van sociale innovatie}

Figuur 6.3 geeft een overzicht van de verschillende vormen van sociale innovatie die de metalektrobedrijven al hebben geïmplementeerd, of gaan doorvoeren. De variabele inzet van personeel wordt door meer dan de helft van de bedrijven genoemd als een sociale innovatie die al is doorgevoerd of dit jaar wordt geïmplementeerd. Bijna 30\% geeft aan dat binnen 5 jaar te zullen doen. Teamgericht werken, zelfsturende teams, of multifunctionele teams worden door ongeveer $20-30 \%$ van de bedrijven op korte termijn geïmplementeerd. Nog eens ruim een kwart verwacht dit binnen 5 jaar te gaan implementeren.

\section{Figuur 6.3}

Sociale innovatie, (\% bedrijven)

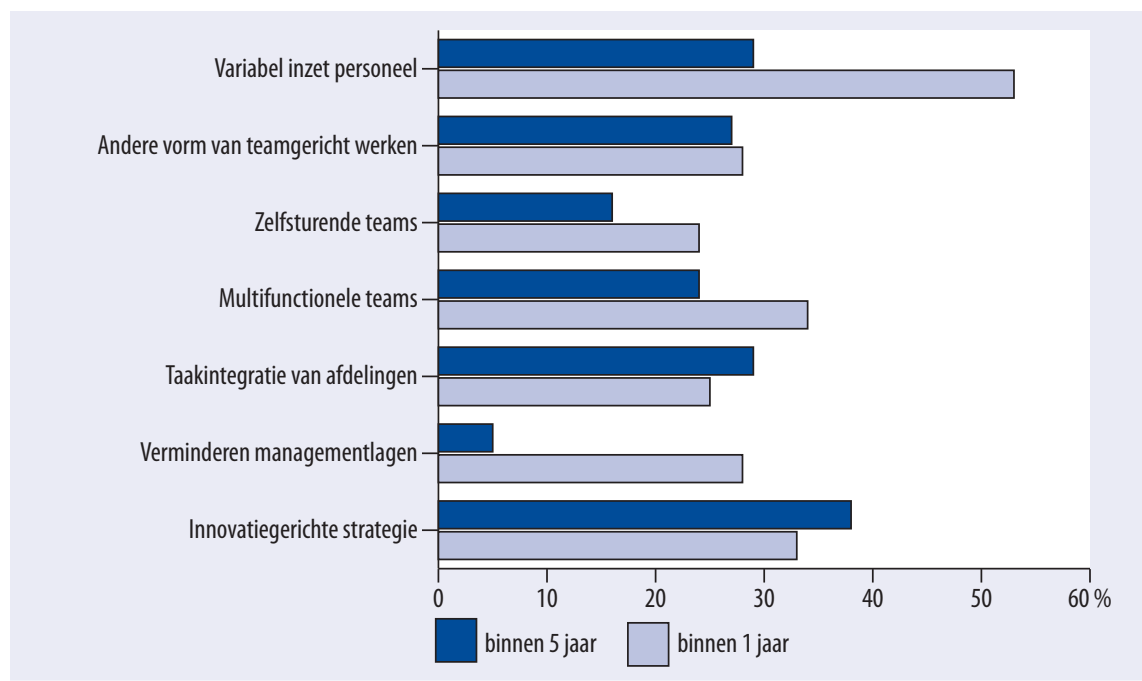

Bron: ROA / Werkgeverspanel Metalektro 2007

Ruim een kwart van de Metalektrobedrijven is al overgegaan tot het verminderen van het aantal managementlagen, of overweegt dit op korte termijn te doen. Het is opmerkelijk dat er vrijwel geen bedrijven zijn die dit aangeven voor een termijn van vijf jaar. De implementatie van een innovatiegerichte strategie wordt wel door veel bedrijven overwogen, maar dan vaak op de wat langere termijn van vijf jaar. $38 \%$ van de bedrijven geeft aan binnen vijf jaar een innovatiegerichte strategie te hebben, terwijl een derde van de bedrijven aangeeft dit nu al te hebben, of binnen een jaar te willen invoeren. 


\section{Doelstellingen van organisatorische veranderingen}

Figuur 6.4 geeft een overzicht van de doelstellingen die de bedrijven beogen te bereiken met verschillende soorten innovaties. Daarbij wordt gekeken naar de volgende doelstellingen:

- hogere productiviteit per werknemer;

- het bereiken van kwalitatief meer hoogwaardige werkgelegenheid;

- kwaliteitsverbetering van producten;

- flexibilisering van de productie;

- als werkgever aantrekkelijker worden.

Daarbij wordt ook aangegeven of deze doelstellingen al zijn gerealiseerd, of - als dat niet het geval is - of deze doelstellingen op de korte termijn van I jaar, of op de langere termijn van vijf jaar zullen worden bereikt.

\section{Figuur 6.4a}

Doelstellingen die bedrijven beogen met sociale innovatie en moment van realisatie: innovatiegerichte strategie (\% bedrijven)

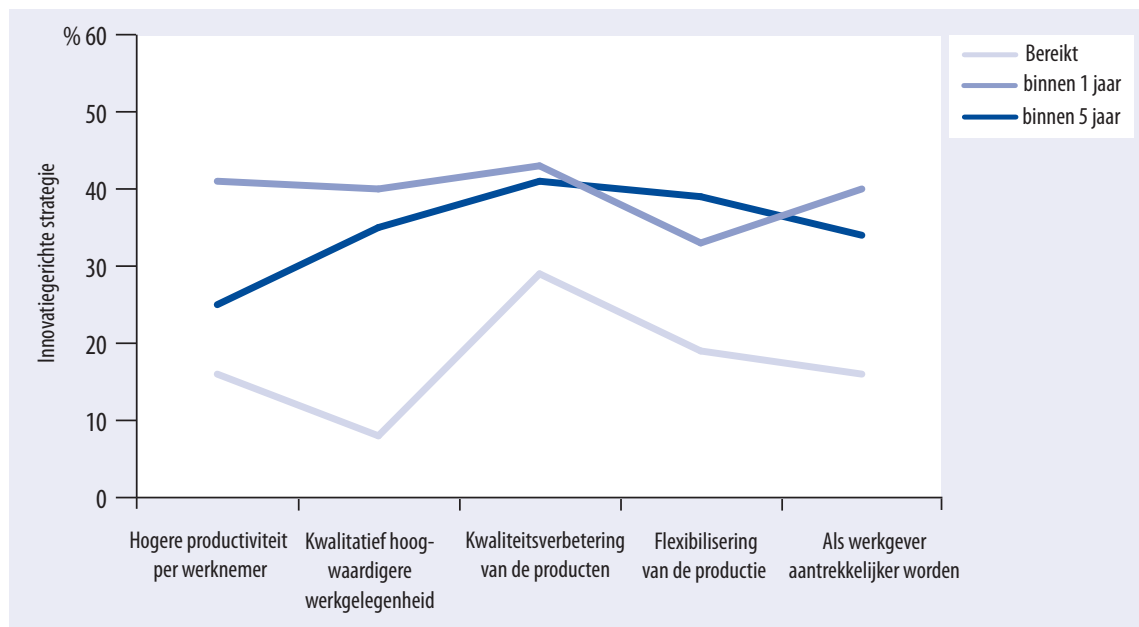

Bron: ROA / Werkgeverspanel Metalektro 2007

Bedrijven verwachten dat het implementeren van een innovatiegerichte strategie (figuur 6.4a) al op korte termijn leidt tot een hogere productiviteit en kwalitatief meer hoogwaardige werkgelegenheid. Daarentegen verwacht men dat de kwaliteitsverbetering van producten pas op wat langere termijn gerealiseerd kan worden. Door taakintegratie hopen bedrijven vooral een meer hoogwaardige werkgelegenheid te kunnen bieden. Innovatiegerichte bedrijven lopen voorop in het gebruik van nieuwe organisatievormen en productieprocessen. Dit is aantrekkelijk voor werknemers, omdat zij zo voorop lopen in het gebruik en de implementatie van deze processen. Veel metalektrobedrijven verwachten dat de aantrekkelijkheid als werkgever pas over een termijn van vijf jaar te kunnen bereiken. 


\section{Figuur 6.4b}

Doelstellingen die bedrijven beogen met sociale innovatie en moment van realisatie: multifunctionele teams (\% bedrijven)

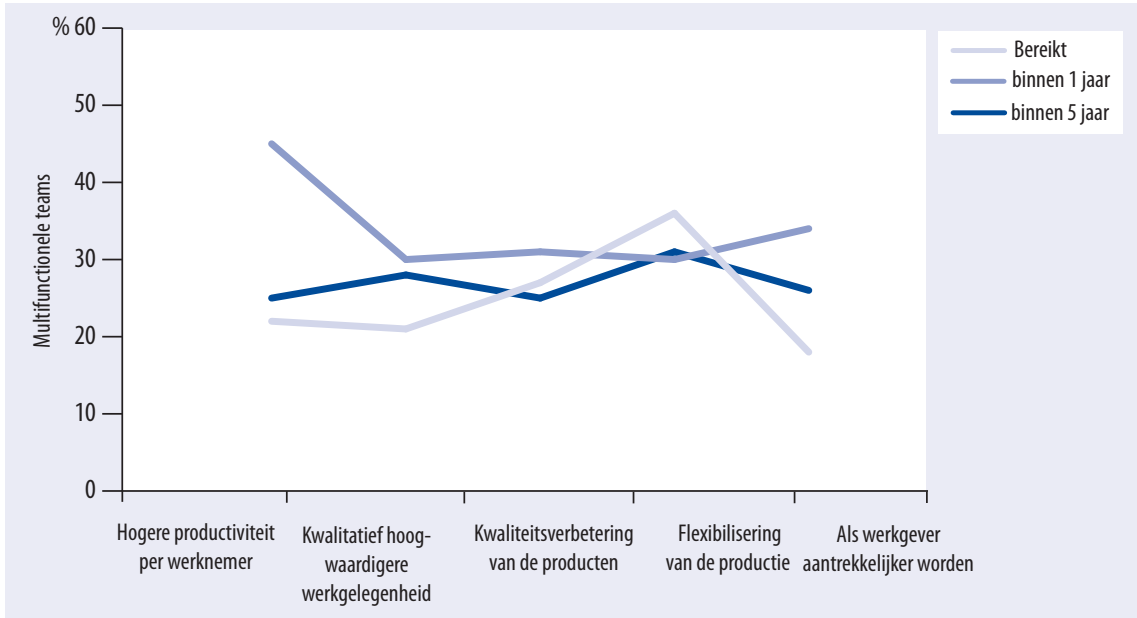

Bron: ROA / Werkgeverspanel Metalektro 2007

\section{Figuur $6.4 \mathrm{C}$}

Doelstellingen die bedrijven beogen met sociale innovatie en moment van realisatie: zelfsturende teams (\% bedrijven)

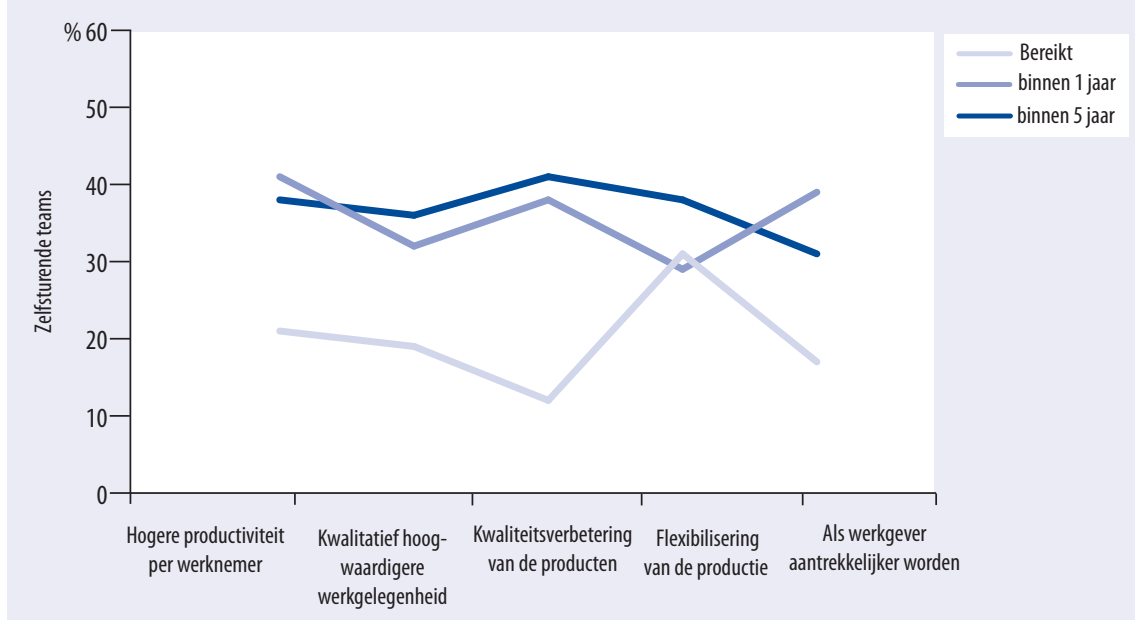

Bron: ROA / Werkgeverspanel Metalektro 2007

Zelfsturende teams (figuur 6.4b), multifunctionele teams (figuur 6.4c) en andere vormen van teamgericht werken (figuur 6.4d) scoren hoog op veel doelstellingen. Veel bedrijven die met multifunctionele teams (willen gaan) werken verwachten dat dit binnen een jaar tot een hogere arbeidsproductiviteit en een flexibilisering van 
de productie zal leiden. Bij zelfsturende teams worden vaak doelstellingen voor de wat langere termijn genoemd. Teamgericht werken maakt bedrijven ook attractiever als werkgever. Dit zal niet meteen, maar op termijn gebeuren. De meeste bedrijven verwachten dat dit binnen één jaar te realiseren is (tussen de 30-40\%), terwjil een aantal bedrijven deze effecten pas na een periode van vijf jaar verwacht (20-35\%). Veel bedrijven verwachten dus dat met teamgerichte organisatieveranderingen veel doelen tegelijk kunnen worden bereikt. Vaak zijn leerprocessen nodig om deze doelen te bereiken.

\section{Figuur 6.4d}

Doelstellingen die bedrijven beogen met sociale innovatie en moment van realisatie: andere vorm van teamgericht werken (\% bedrijven)

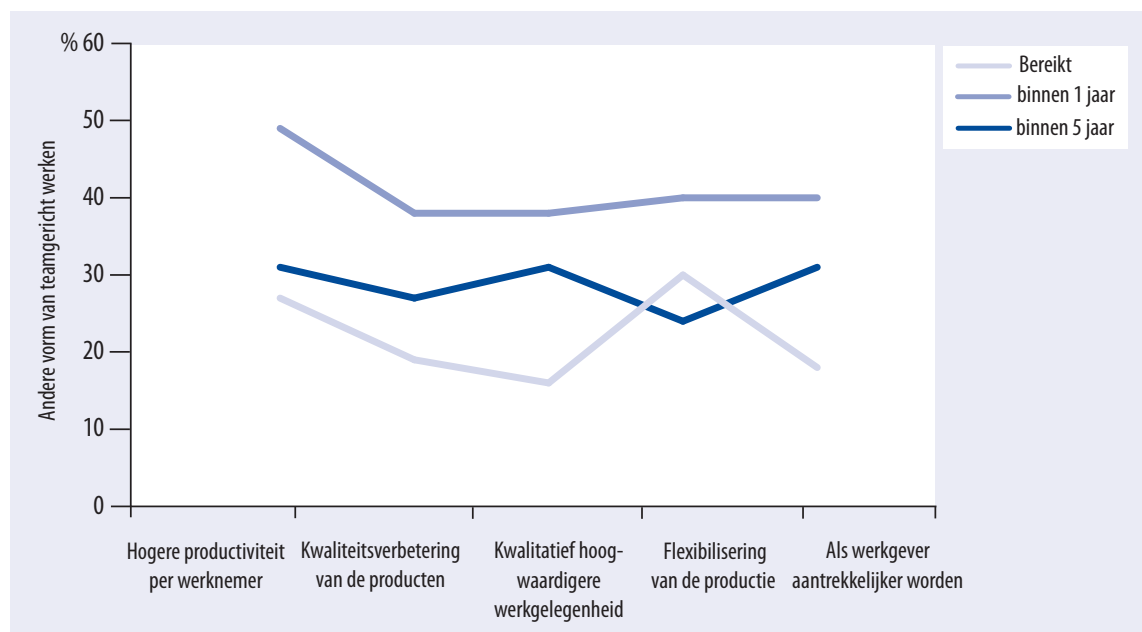

Bron: ROA / Werkgeverspanel Metalektro 2007

De bedrijven die hun technisch personeel variabel (willen gaan) inzetten, verwachten dat ze hiermee snel een flexibilisering van de productie kunnen realiseren en dat dit hun aantrekkelijkheid als werkgever vergroot. De bedrijven die deze maatregel gebruiken, verwachten hiermee een hogere productiviteit en kwalitatief hoogwaardigere werkgelegenheid te bereiken op de korte tot middellange termijn.

Het integreren van taken heeft in de Metalektrobedrijven vooral een effect op de korte en middellange termijn. Bedrijven verwachten op korte termijn met name een hogere productiviteit per werknemer te realiseren, en op de langere termijn ook een kwalitatief hoogwaardigere werkgelegenheid. Een derde van de bedrijven verwacht dat taakintegratie binnen één jaar ten goede komt van de kwaliteit van hun producten en de flexibilisering van de productie. Nog eens $45 \%$ van de bedrijven verwacht dit binnen 5 jaar te realiseren. Met name het hoogwaardiger worden van de werkgelegenheid zal ertoe leiden dat de Metalektrobedrijven als werkgever aantrekkelijker zullen worden. 


\section{Figuur 6.4e}

Doelstellingen die bedrijven beogen met sociale innovatie en moment van realisatie: variabele inzet personeel (\% bedrijven)

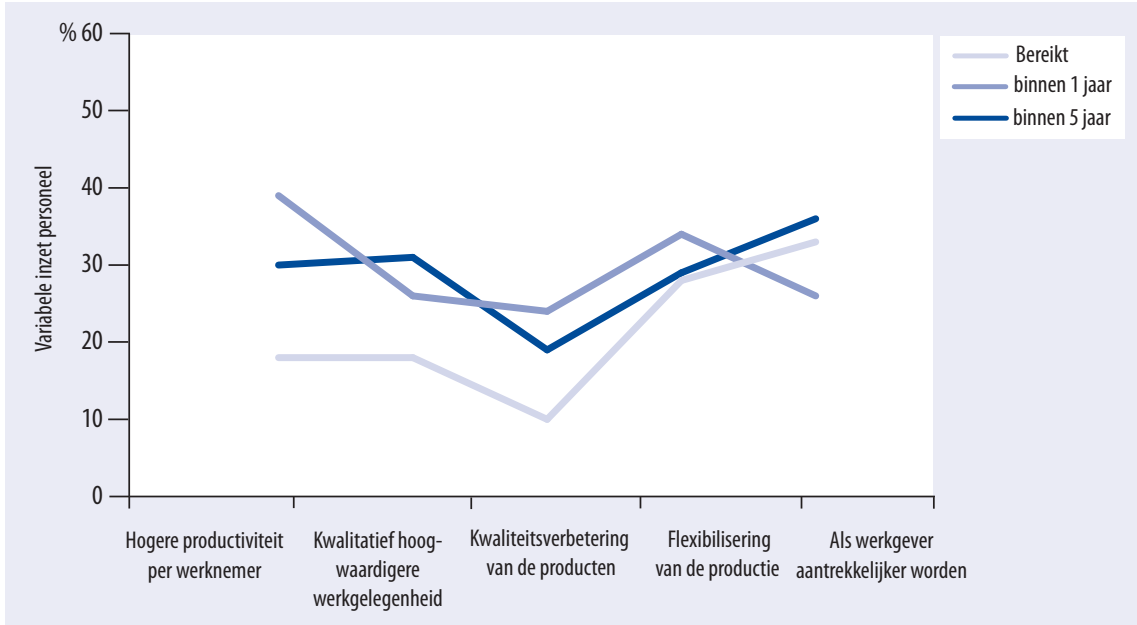

Bron: ROA / Werkgeverspanel Metalektro 2007

\section{Figuur 6.4f}

Doelstellingen die bedrijven beogen met sociale innovatie en moment van realisatie: taakintegratie over afdelingen (\% bedrijven)

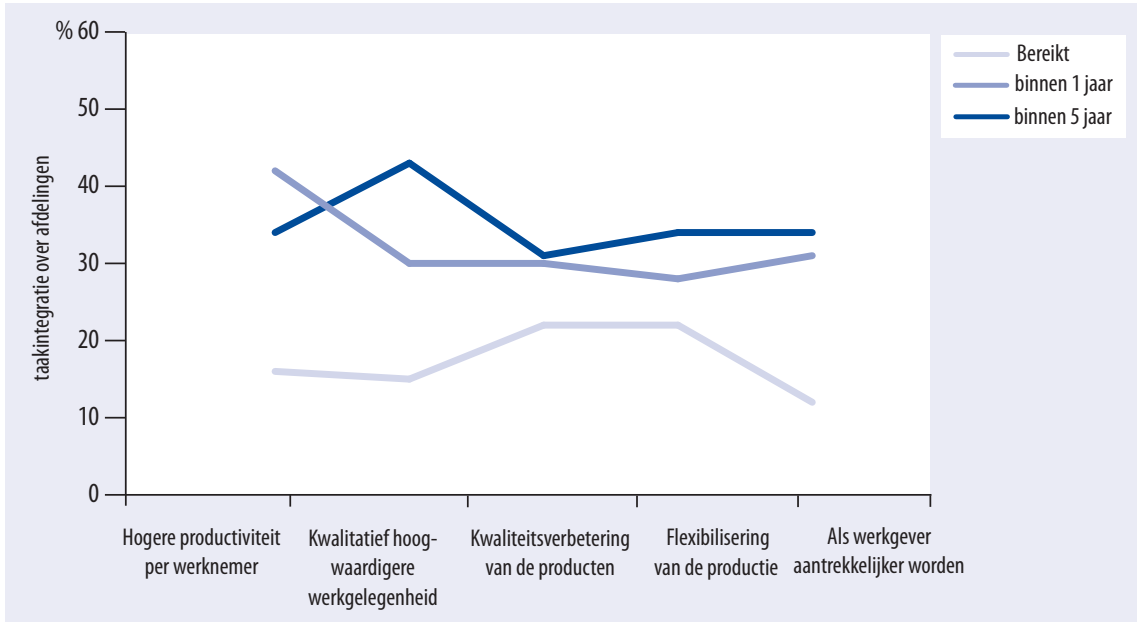

Bron: ROA / Werkgeverspanel Metalektro 2007

Bedrijven die het aantal managementlagen willen verlagen, verwachten vooral direct of op korte termijn resultaat. Bijna 50\% van de bedrijven geeft aan direct een hogere productiviteit te verwachten, en ruim een derde verwacht dit binnen een jaar. Ook wordt verwacht dat dit op korte termijn ten goede komt aan de aantrekkelijkheid als werkgever. 


\section{Figuur 6.49}

Doelstellingen die bedrijven beogen met sociale innovatie en moment van realisatie: verminderen managementlagen (\% bedrijven)

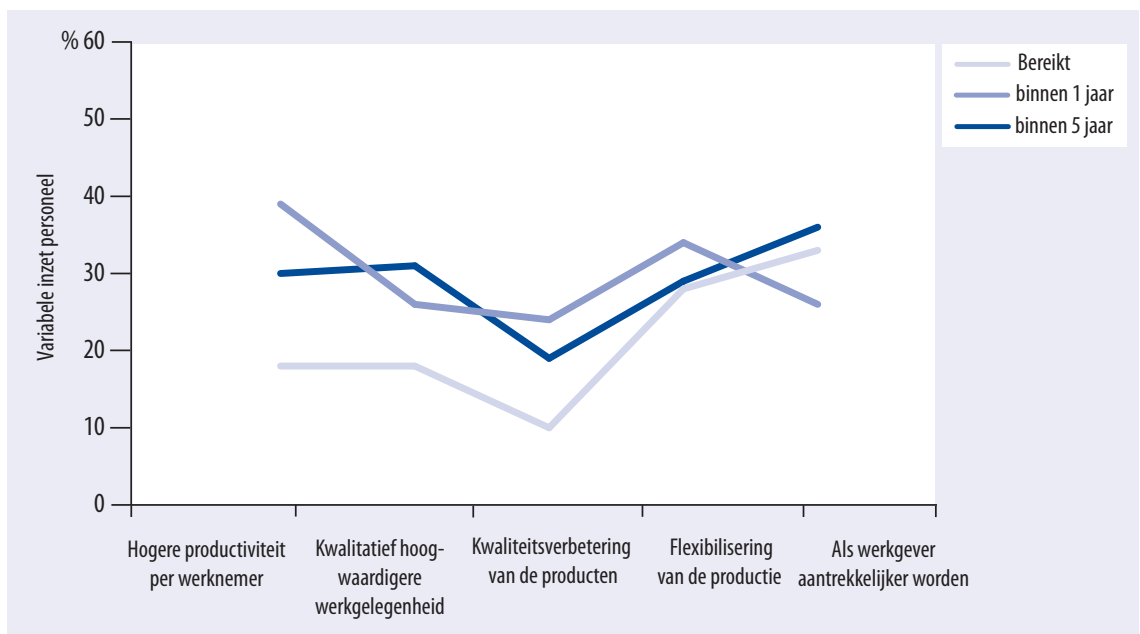

Bron: ROA / Werkgeverspanel Metalektro 2007

\section{"Aandacht voor het personeel is rendabel"}

De ervaring van bedrijven met nieuwe werkvormen is vaak goed: “Korte lijnen, samen oplossingen zoeken." En: "Veel 'lean' projecten, daar betrek je alle medewerkers bij." De meeste werknemers blijken deze uitdaging wel aan te willen gaan, maar bedrijven berichten ook over problemen: "Je maakt er sommige mensen niet blij mee." Belangrijk is ook om te communiceren wat de doelstellingen van het bedrijf zijn, en waarom bepaalde maatregelen genomen worden: "Een keer per jaar moet je samen met je personeel bespreken: waar ga je naartoe, wat willen we bereiken." Kort samengevat: "Aandacht voor het personeel is rendabel."

\section{Personeel en innovatie}

Technologische innovaties en organisatorische veranderingen kunnen door het personeel ook als bedreigend ervaren worden. Zeker als het gaat om procesinnovaties, nieuwe werkvormen, of andere competentie-eisen. Veel Metalektrobedrijven zijn zich bewust van het belang om hier adequaat op in te spelen. Figuur 6.5 laat zien dat $58 \%$ van de bedrijven door "on-the-job" training hun personeel op veranderingen voorbereidt. Daarnaast worden er in $45 \%$ van de bedrijven trainingen of cursussen gegeven die werknemers voorbereiden op de geplande veranderingen. Bijna de helft van de bedrijven geeft aan dat zij bij innovaties rekening probeert te houden met de feedback van werknemers op het vernieuwingsproces. Ook probeert $40 \%$ van de bedrijven hun werknemers voor te lichten over de veranderingen. $30 \%$ van de bedrijven ruimt bij vernieuwingsprocessen meer tijd in om het personeel langzaam vertrouwd te maken met de veranderingen. 


\section{Figuur 6.5}

Wijze waarop bedrijven inspelen op de veranderingen die innovaties voor het personeel met zich meebrengen, 2007 (\% bedrijven)

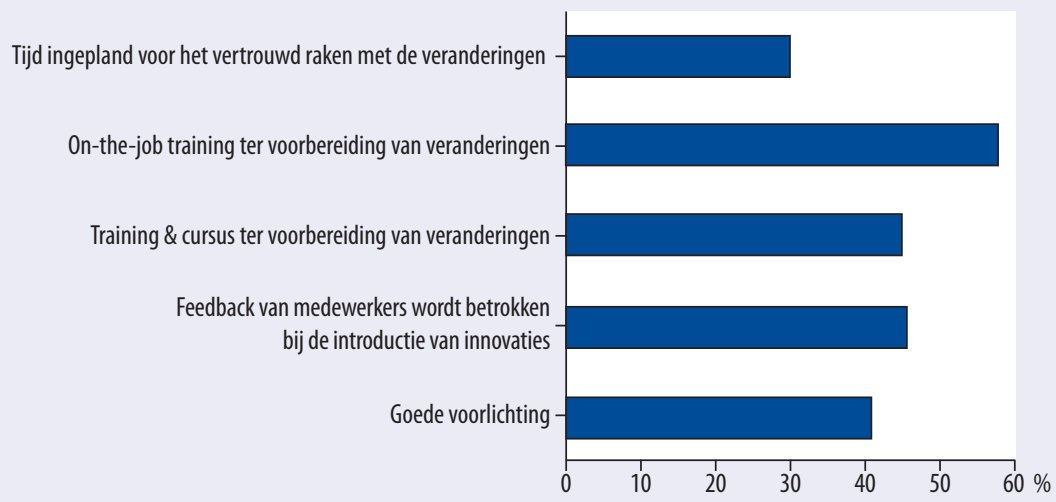

Bron: ROA / Werkgeverspanel Metalektro 2007

\section{Outsourcing}

Figuur 6.6 laat zien in hoeverre metalektrobedrijven bepaalde activiteiten in de komende vijf jaar willen uitbesteden aan andere bedrijven in Nederland of in het buitenland. Ruim een derde van de bedrijven geeft aan activiteiten naar het buitenland te willen verplaatsen, terwijl $20 \%$ activiteiten naar andere bedrijven in Nederland wil outsourcen. Er zijn ook opmerkelijk veel bedrijven die 'Research \& Development' activiteiten willen verplaatsen: IO\% verwacht in de komende vijf jaar dergelijke hoogwaardige activiteiten naar het buitenland te verplaatsen, terwijl 19\% dit binnen Nederland wil uitbesteden. Administratieve activiteiten worden minder vaak uitbesteed: $8 \%$ van de bedrijven geeft aan deze activiteiten uit te besteden aan Nederlandse bedrijven, terwijl $6 \%$ dit internationaal doet.

\section{Figuur 6.6}

Outsourcing van verschillende activiteiten, 2008-2012 (\% bedrijven)

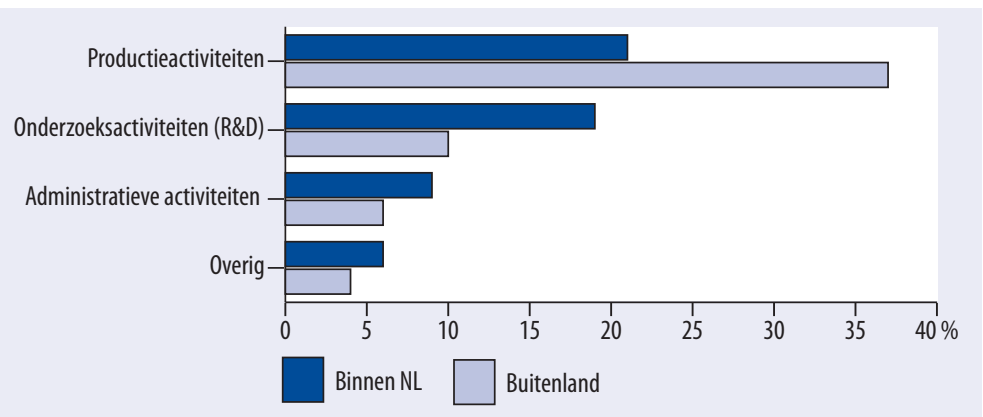

Bron: ROA / Werkgeverspanel Metalektro 2007 


\section{Figuur 6.7}

Behoefte en daadwerkelijke brede inzetbaarheid personeel, 2007 (\% bedrijven)

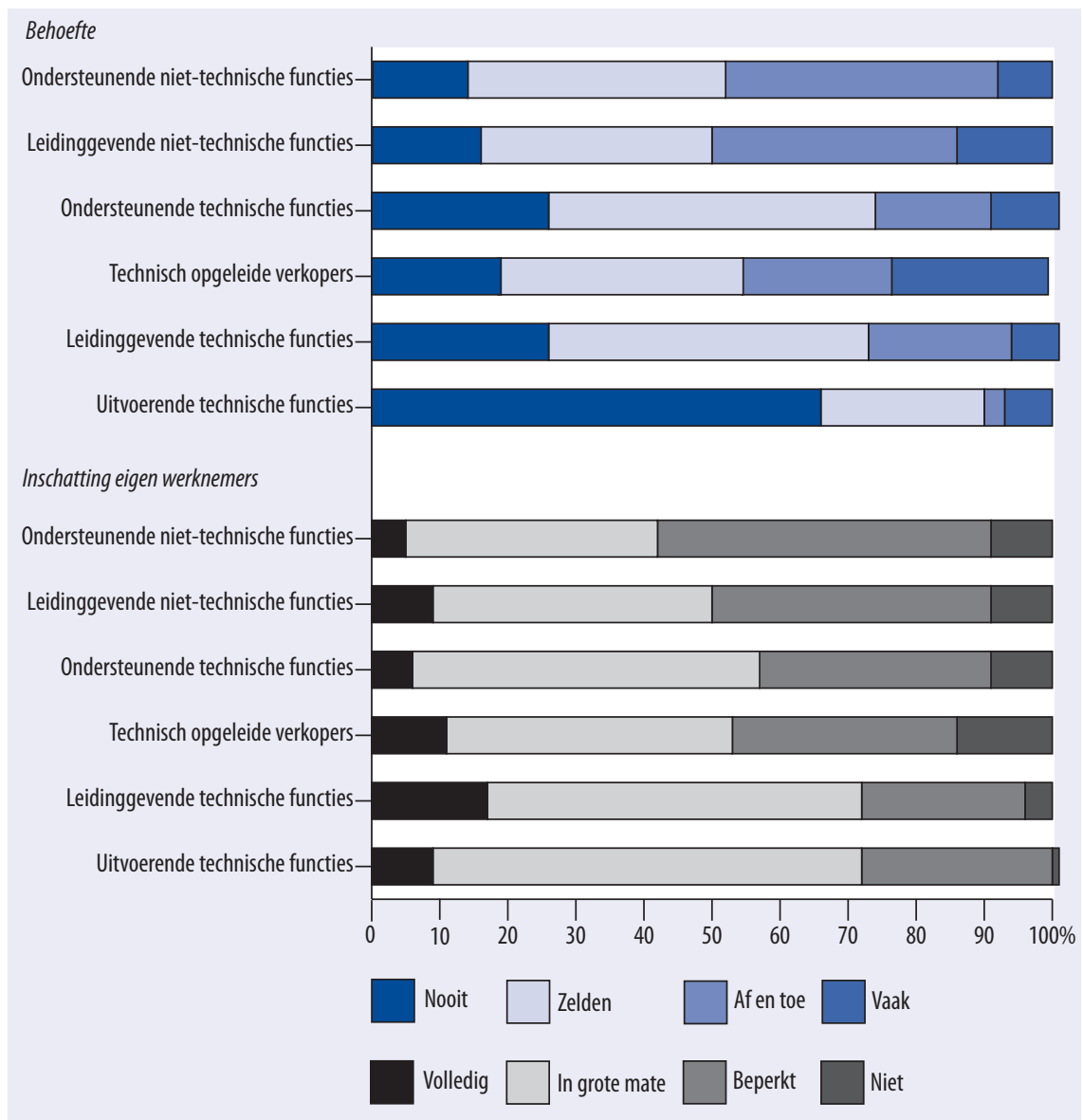

Bron: ROA / Werkgeverspanel Metalektro 2007

\subsection{Brede inzetbaarheid}

Brede inzetbaarheid van het personeel van de metalektrobedrijven is om verschillende redenen van groot belang. Dit belang komt op verschillende gebieden naar voren. $\mathrm{Zo}_{\mathrm{o}}$ zijn nieuwe werkvormen vaak afhankelijk van teams met breed inzetbare technici. Medewerkers zijn vaak gemotiveerder wanneer zij verschillende aan elkaar gerelateerde taken mogen invullen, vanuit een eigen verantwoordelijkheid. Zulke banen worden dan afwisselender en uitdagender in vergelijking tot sterk gespecialiseerde functies. Bedrijven geven vooral bij uitvoerende technische functies aan dat zij vaak behoefte hebben aan brede inzetbaarheid. Figuur 6.7 laat ook zien dat meer dan $60 \%$ van de bedrijven vaak behoefte heeft aan breed inzetbaar personeel. Bij de leidinggevende 
en de ondersteunende technische functies is dit $20 \%$ van de bedrijven; voor overige functies is dit nog minder.

Bedrijven schatten de brede inzetbaarheid onder uitvoerende en leidinggevende technische functies het hoogst in. Figuur 6.7 laat zien dat ruim $70 \%$ van de bedrijven aangeeft dat hun werknemers volledig of in grote mate breed inzetbaar zijn. Opvallend is hier wel dat er maar weinig bedrijven zijn die vinden dat hun werknemers volledig breed inzetbaar zijn. Veel bedrijven geven aan dat hun werknemers "in grote mate" breed inzetbaar zijn.

Bij minder dan de helft van de bedrijven zijn de technisch opgeleide verkopers en de medewerkers in niet-technische functies in grote mate breed inzetbaar. Dit is duidelijk minder dan de behoefte aan breed inzetbaar personeel voor deze functiecategorieën. 


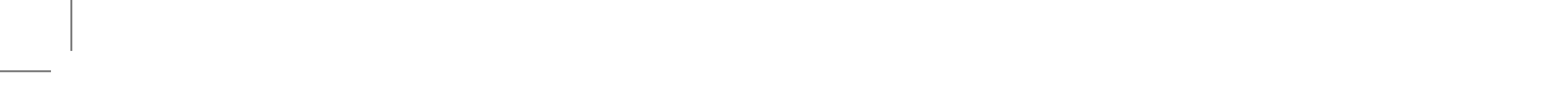




\section{Vergrijzing en het moderne HRM beleid}

In dit hoofdstuk richten we ons op maatregelen die bedrijven voor oudere werknemers nemen en de problemen die bedrijven verwachten bij het vervangen van een hogere uitstroom van ouder personeel. Paragraaf 7.I richt zich op de verwachte uitstroom en de gerelateerde vervangingsvraagproblematiek. Hier is te zien dat er met name voor het uitvoerend technisch personeel een grote vervangingsvraag zal ontstaan. Veel bedrijven verwachten voor deze groep dan ook problemen bij het invullen van de hierdoor veroorzaakte vacatures. In paragraaf 7.2 worden specifieke maatregelen ten behoeve van oudere werknemers beschreven. Oudere werknemers hebben vaak andere behoeften en doelstelingen dan hun jongere collega's. Ook zijn zij soms fysiek niet meer in staat om bepaald werk te doen.

\subsection{Uitstroom en vervangingsprobleem}

De Metalektro heeft nog altijd te kampen met vergrijzing. Zoals in hoofdstuk I al werd aangegeven, is meer dan een vijfde van de werknemers 50 jaar of ouder. Dit is overigens vergelijkbaar met andere industriële sectoren. De vergrijzing van het personeelsbestand van veel metalektrobedrijven weerspiegelt zich slechts ten dele in de verwachte uitstroom. Zo verwachten bedrijven slechts voor de uitvoerende technische functies hoge uitstroompercentages. De uitstroom in de meeste andere functies wordt ingeschat rond de drie procent. Dit is eerder een waarde die te verwachten is bij een evenwichtige verdeling over alle leeftijdsgroepen.

Figuur 7.I geeft een beeld van de uitstroom die de metalektrobedrijven voor de komende vijf jaar verwachten doordat personeel met (pre-)pensioen zal gaan. Voor de uitvoerende technische functies wordt de grootste uitstroom vanwege pensionering verwacht. De bedrijven verwachten dat gemiddeld $9 \%$ van de werkenden in deze functies binnen 5 jaar met pensioen zal gaan. Bij de andere functies is de verwachte uitstroom van medewerkers die met pensioen gaan veel lager. Voor de ondersteunende technische functies wordt nog een uitstroom van bijna $5 \%$ verwacht. Voor de overige technische en niet-technische functies slechts een uitstroom van rond de $3 \%$. 
Ook zijn er grote verschillen in de moeilijkheden die bedrijen verwachten om hun personeel te vervangen. Figuur 7.2 geeft aan dat voor het niet-technische personeel de geringste vervangingsproblemen worden verwacht. Minder dan IO\% van de bedrijven verwacht voor deze functies de komende jaren problemen om hun personeel te vervangen.

\section{Figuur 7.1}

Werknemers die de komende 5 jaar met (pre-)pensioen zullen gaan, 2007 (\% werkenden)

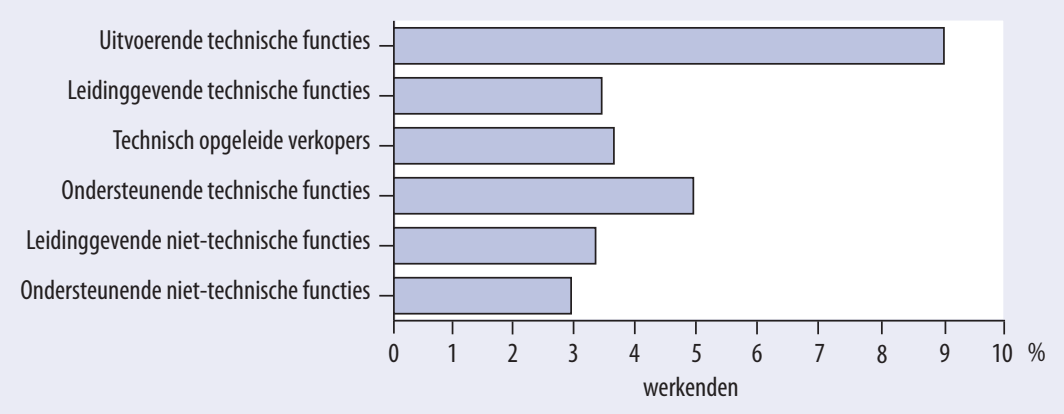

Bron: ROA / Werkgeverspanel Metalektro 2007

Daarentegen worden er veel problemen verwacht bij de vervanging van het uitvoerend technisch personeel. Meer dan $40 \%$ van de bedrijven verwacht hier veel vervangingsproblemen. Iets minder dan $40 \%$ van de bedrijven verwacht veel problemen bij de vervanging van het vertrekkende leidinggevend technisch personeel, terwijl ruim $35 \%$ van de bedrijven problemen verwacht bij de vervanging van technische verkopers en ondersteunend technisch personeel.

\section{Figuur 7.2}

Verwachte problemen bij het vervangen van werknemers die in de komende 5 jaar met pensioen gaan, 2007 (\% bedrijven)

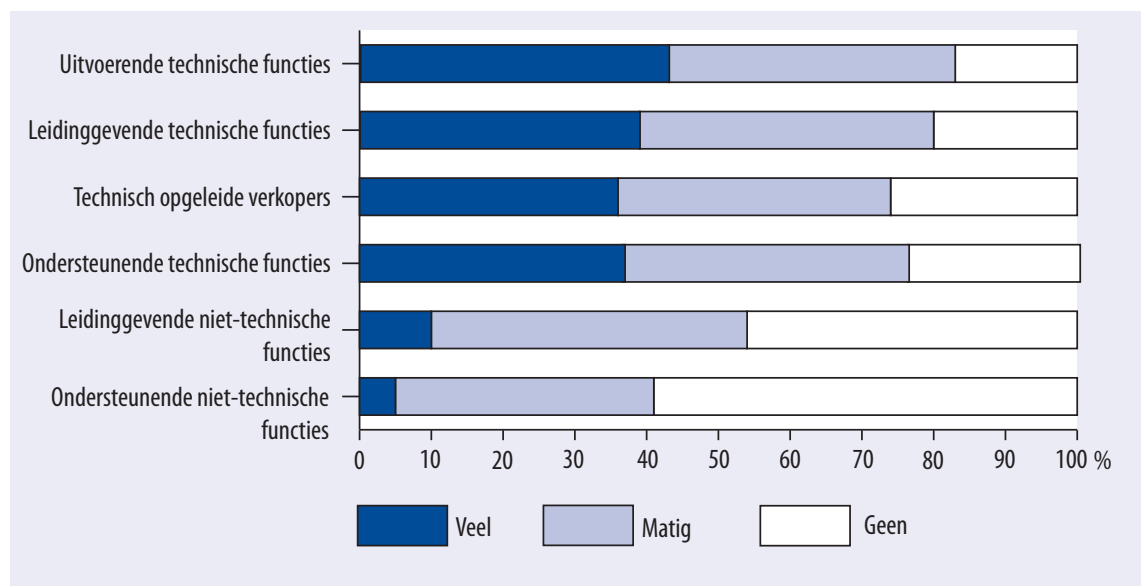

Bron: ROA / Werkgeverspanel Metalektro 2007 
Om de verwachte problemen bij de vervanging van het technisch personeel enigszins op te kunnen vangen, zullen er vroegtijdig maatregelen moeten worden getroffen. Figuur 7.3 geeft een overzicht van de wijze waarop de metalektrobedrijven dit proberen te doen, of de komende jaren willen doen. Veel bedrijven willen hun vervangingsproblemen beperken door nieuw personeel aan te nemen dat nog niet over de nodige competenties beschikt. Zij willen deze nieuwe medewerkers zelf opleiden. Bijna 80\% van de bedrijven doet dit momenteel al, terwijl circa $15 \%$ van de bedrijven dit in de toekomst wil gaan doen. Zo'n $85 \%$ van de bedrijven wil ook nieuwe goed opgeleide medewerkers aannemen, en een even grote groep bedrijven wil de vervangingsproblemen opvangen door hun relatie met het onderwijsveld te intensiveren. Zo kunnen vroegtijdig banden worden gelegd tussen scholieren en het bedrijf. Bijna de helft van de bedrijven is nu al bezig extra personeel te werven om de vervangingsproblematiek te beperken. Meer dan de helft van de bedrijven probeert ook zijn aantrekkelijkheid als werkgever te vergroten om zo makkelijker hun personeel te kunnen vervangen, terwijl $20 \%$ dit wil gaan doen (zie ook hoofdstuk 5 en 6 ).

Het werven van medewerkers uit het buitenland is slechts een oplossing voor een klein gedeelte van de bedrijven. Een vijfde van de bedrijven geeft aan dat zij daar nu al mee bezig zijn, en iets minder dan een derde wil dit in de toekomst doen.

Behalve door het aannemen van nieuw personeel kan men ook proberen de vervangingsproblemen op andere manieren te beperken. Zo probeert $28 \%$ van de bedrijven de vervangingsvraagproblematiek naar de toekomst te verschuiven door het huidige personeel te stimuleren om langer door te werken. Nog eens $20 \%$ van de bedrijven wil dit in de toekomst ook gaan doen. De minder orthodoxe oplossing om mensen die al met pensioen zijn terug te halen wordt door $30 \%$ van de bedrijven al toegepast, en nog eens $8 \%$ van de bedrijven wil dit in de toekomst gaan doen. Meer dan de helft van de bedrijven probeert hun vervangingsproblemen te beperken door personeel breder inzetbaar te maken door middel van taakroulatie. $46 \%$ van de bedrijven tracht de vervangingsproblemen beperken door het huidige personeel bij te scholen, en nog eens $33 \%$ wil dat in de toekomst gaan doen.

Arbeidskrachtbesparende technologie is een andere manier om de werknemers die vervangen moeten worden overbodig te maken. Een derde van de bedrijven denkt op deze manier vervangingsproblemen te beperken, en nog eens een kwart van de bedrijven wil dit gaan doen. Slechts $14 \%$ van de bedrijven probeert de vervangingsproblemen op te lossen door een deel van de productie naar het buitenland te verplaatsen, en nog eens I2\% van de bedrijven wil dit gaan doen. 


\section{Figuur 7.3}

Maatregelen om toekomstige vervangingsproblemen te beperken (\% bedrijven)

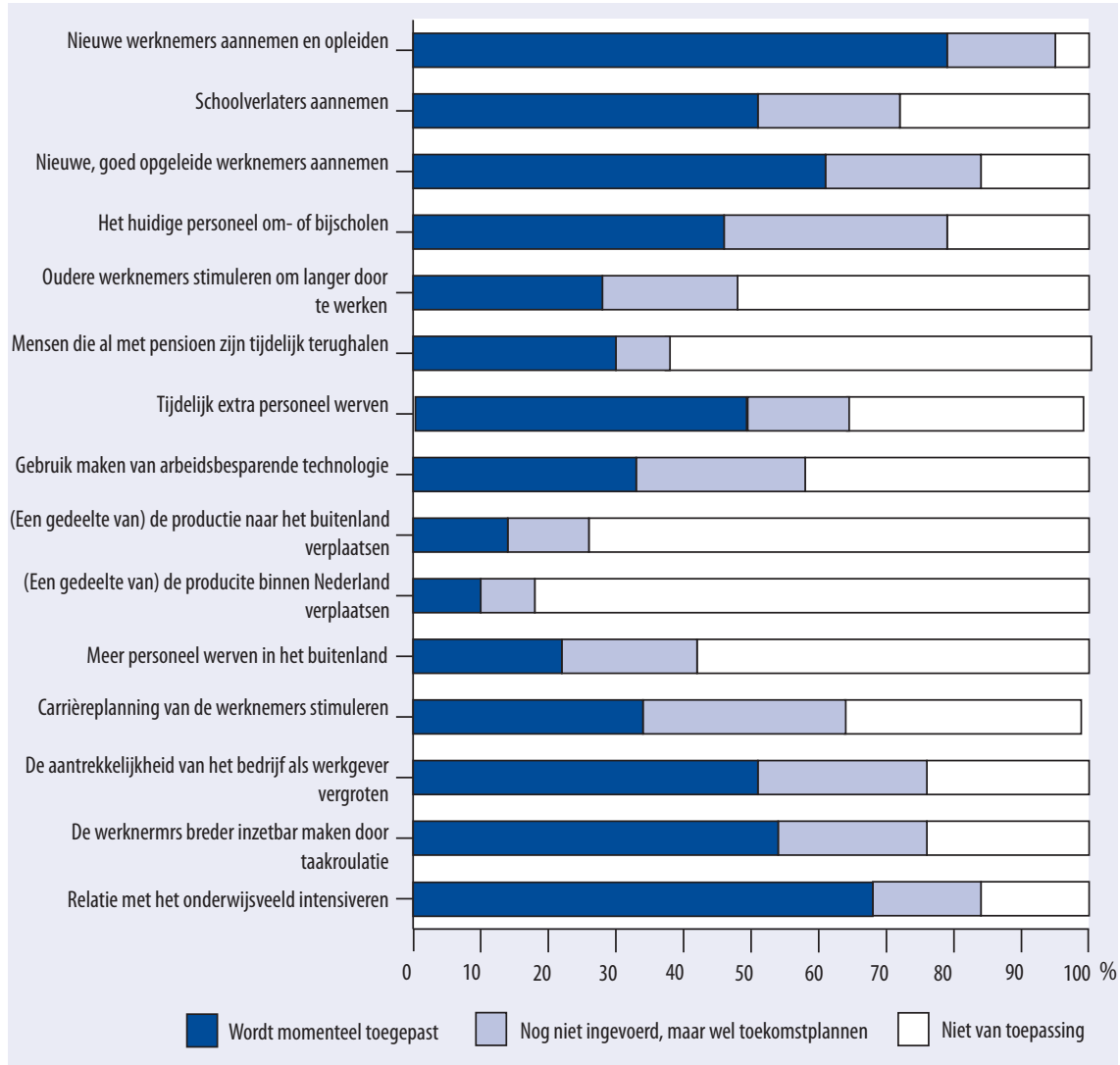

Bron: ROA / Werkgeverspanel Metalektro 2007

\subsection{Maatregelen voor oudere werknemers}

De vervangingsproblematiek is maar een van de redenen om de vergrijzing als een serieuze uitdaging te zien voor de bedrijven in de Metalektro sector. Al voordat werknemers vertrekken, zijn zij een leeftijdsgroep waarvoor bedrijven meer aandacht moeten hebben dan in het nabije verleden. Het pensioenvooruitzicht kan zowel de werknemer als de werkgever terughoudend maken om nog te blijven investeren in het op peil houden van de kennis en de vaardigheden van de oudere werknemer. Dit kan negatieve gevolgen hebben voor het functioneren en de productiviteit van oudere werknemers, terwijl zij vaak de meest ervaren krachten zijn.

Oudere werknemers zijn ook vaker fysiek minder goed in staat om nog aan alle eisen van hun vak te voldoen. Om te voorkomen dat zij voortijdig met hun werk stoppen 
en daarmee een vervangingsprobleem veroorzaken, zullen metalektrobedrijven door middel van een levensfasebewust active aging beleid op deze mogelijke competentieveroudering en inzetbaarheidsproblemen moeten inspelen.

\section{Inzet van oudere medewerkers in de praktijk}

Lang niet alle bedrijven zijn enthousiast over een speciale aanpak van oudere medewerkers. Een personeelsfunctionaris spreekt zijn ervaring uit: "Het kan demotiverend zijn voor oudere medewerkers om ze apart bij te scholen. Sommige mensen vinden beleid voor oudere medewerkers discriminerend. Het klinkt alsof je met 45 al oud bent." Dit wordt aangevuld door anderen die aangeven "een beetje moe te worden van al die aandacht voor vergrijzing en leeftijdsbewust personeelsbeleid." Maar men ziet de noodzaak om duidelijkheid te krijgen over de inzetbaarheid van ouder personeel: “We spreken gewoon met onze (toekomstige) VUT'ers: Wat willen ze? Eruit, of nog een tijdje mee draaien?" De begeleiding van jongere werknemers en stagiaires is een andere mogelijkheid om de ervaring van hun oudere werknemers goed in te zetten: "Er zijn van die'vaderfiguren', die zijn communicatief sterk, en het is handig om hen hiervoor in te zetten."

\section{Figuur 7.4}

Maatregelen die metalektrobedrijven voor oudere werknemers nemen (\% bedrijven)

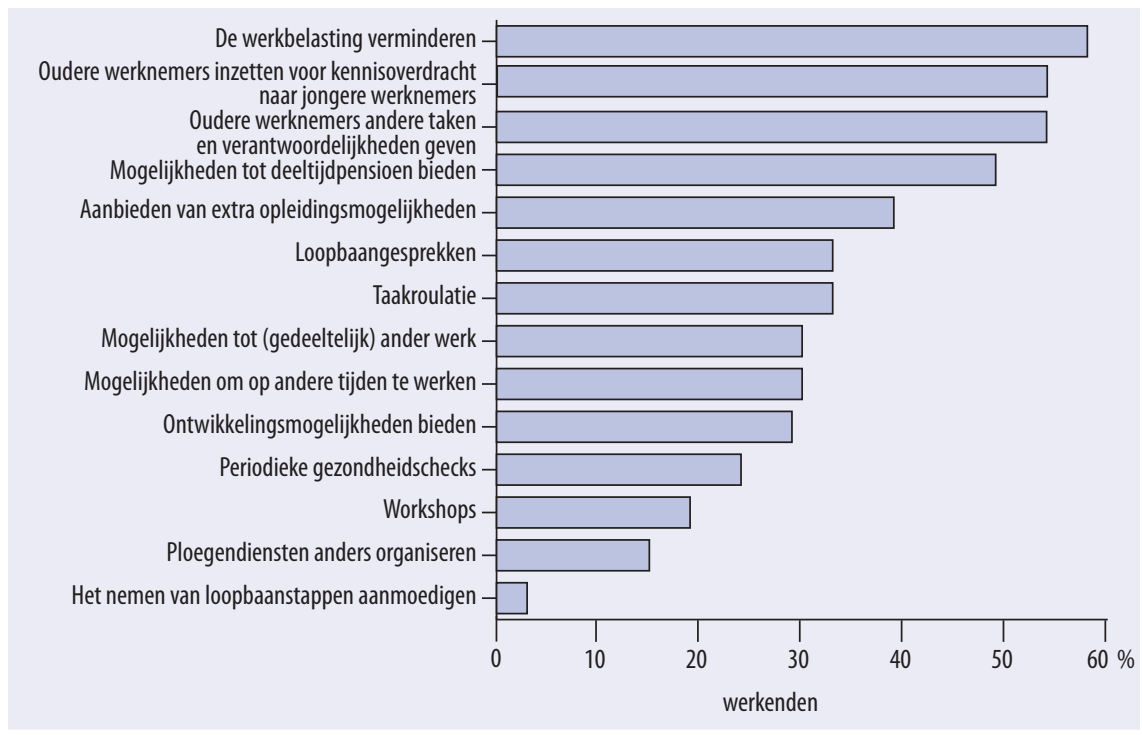

Bron: ROA / Werkgeverspanel Metalektro 2007

Figuur 7.4 geeft een overzicht van de HR instrumenten waarmee bedrijven oudere medewerkers goed inzetbaar proberen te houden. Vaak worden oudere werknemers op plekken ingezet waar zij hun lange ervaring het beste kunnen inzetten en waar mogelijke fysieke tekortkomingen minder belangrijk zijn. Zo geeft meer dan de helft van de bedrijven aan dat zij oudere werknemers inzetten voor de kennisoverdracht 
naar jonge medewerkers. Hierdoor kan de continuïteit in het leer- en ervaringsproces van het personeel worden bevorderd. Ook door werkbelasting te verminderen (58\%), gedeeltelijk ander werk aan te bieden (30\%) en door mogelijkheden tot deeltijdpensioen $(49 \%)$, kan men oudere werknemers stimuleren en in staat stellen om langer door te werken.

Voor oudere werknemers kan het zwaar zijn om in ploegendienst te werken. Zo'n I5\% van de bedrijven probeert daarom de ploegendienst voor oudere medewerkers anders te organiseren. Ongeveer een derde van de bedrijven zoekt naar andere oplossingen gericht op de inhoud van het werk, zoals taakroulatie of het aanbieden van ander werk. Tevens kan er een speciaal trainings- en loopbaanbeleid worden ingevoerd voor oudere werknemers. Een derde van de bedrijven biedt het oudere personeel dan ook loopbaangesprekken aan, terwijl bijna $40 \%$ van de bedrijven extra opleidingsmogelijkheden aanbiedt. 


\section{De Metalektro in de toekomst}

In dit hoofdstuk schetsen we een beeld van de toekomstige ontwikkelingen in de Metalektro. In paragraaf 8.I kijken we naar de verwachte arbeidsmarktontwikkelingen voor de komende jaren. Daarbij gaan we achtereenvolgens in op de korte termijn verwachtingen van de bedrijven en de ontwikkelingen op middellange termijn. Paragraaf 8.2 gaat in op de toekomstige wervingsproblemen, waarna paragraaf 8.3 de verwachte toekomstige functieveranderingen bespreekt. Paragraaf 8.4 geeft ten slotte een overzicht van de toekomstige speerpunten van het HRM beleid.

\subsection{Verwachte ontwikkelingen op de arbeidsmarkt 2007-2012}

Voor een goede planning van de personeelsbehoefte en het realiseren van deze planning, is het van groot belang om goed inzicht te hebben in de toekomstige ontwikkelingen op de arbeidsmarkt. Dit vereist prognoses van de werkgelegenheidsontwikkeling in de sector en de ontwikkeling van de voor de sector belangrijke beroepen en opleidingen. Ook moet er inzicht zijn in de te verwachten vervangingsvraag die voortvloeit uit het vertrek van personeel. In dit hoofdstuk combineren wij gegevens van de Arbeidsmarktmonitor Metalektro met de arbeidsmarktprognoses naar opleiding en beroep van het ROA.

\section{Verwachtingen van de korte termijn ontwikkeling van werkgevers}

De totale werkgelegenheid in de Metalektro in de periode 2008-2009 zal volgens de bedrijven van de Metalektro verder groeien. Dit blijkt uit een vraag waarin we de bedrijven om een inschatting vragen over de groei of krimp over de komende twee jaar. Hierbij onderscheiden we drie functieniveaus: laag, middelbaar en hoger onderwijs. Deze functieniveaus weerspiegelen de eisen van functies, maar deze functies hoeven niet per se ingevuld te worden door een medewerker van dit opleidingsniveau.

De werkgevers in de Metalektro verwachten een verdere verschuiving naar het $\mathrm{MBO}$ en $\mathrm{HBO} / \mathrm{WO}$ niveau ten koste van laagopgeleide werknemers. Figuur 8.I geeft aan dat de werkgevers een uitbreiding verwachten in de werkgelegenheid op het hoogste niveau, $\mathrm{HBO}$ en universitair geschoold, en op het middelbare niveau (MBO). Op het laagste niveau (LBO) verwacht ruim $40 \%$ van de bedrijven een afname. Dit is duidelijk meer dan de krap ıo\% van de bedrijven die ook op dit niveau nog een toename 
verwachten. Interessant is dat bedrijven een verdere uitbreiding van de werkgelegenheid verwacht volgens dit figuur.

Figuur 8.1

Verwachte werkgelegenheidsontwikkeling naar functieniveau, 2008 (\% bedrijven)

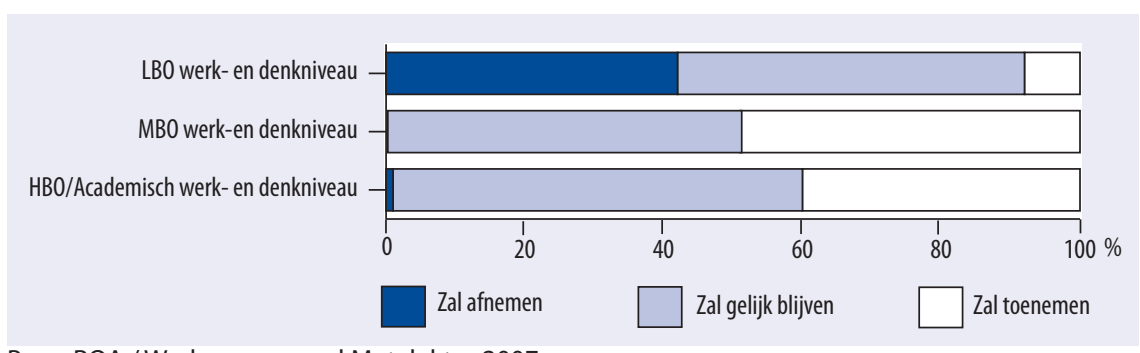

Bron: ROA / Werkgeverspanel Metalektro 2007

Figuur 8.2 vertaalt de krimp- en groeiverwachtingen van de bedrijven naar de daadwerkelijk verwachte werkgelegenheidsontwikkeling in aantallen medewerkers. Duidelijk is te zien dat de verwachte netto afname van de werkgelegenheid op LBO werken denkniveau van I.Ooo werknemers ruimschoots gecompenseerd wordt door een verwachte toename in de werkgelegenheid op $\mathrm{MBO}$ niveau, met ruim 1.600 nieuwe banen, en op $\mathrm{HBO} /$ Academisch werk- en denkniveau, met ruim I.000 nieuwe banen.

\section{Figuur 8.2}

Verwachte werkgelegenheidsontwikkeling per niveau, 2008 (aantallen)

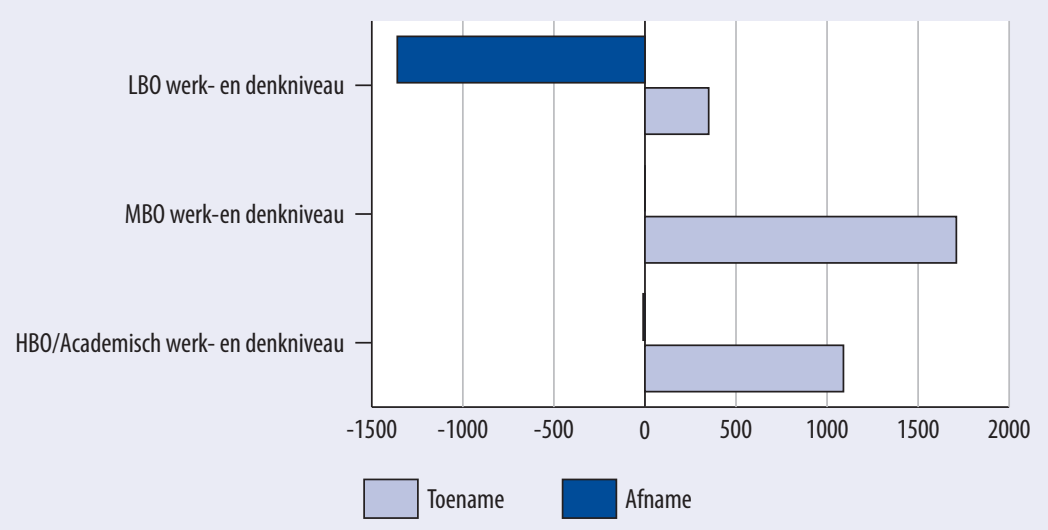

Bron: ROA / Werkgeverspanel Metalektro 2007

\section{Werkgelegenheid: Prognoses voor de middellange termijn}

In de meest recente prognose van de Arbeidsmarkt naar opleiding en beroep tot 2012 (ROA, 2007) wordt voor de bedrijfssector "metaal en elektrotechniek" een lichte 
krimp in de werkgelegenheid verwacht van gemiddeld -0.3\% per jaar voor de periode van 2007-20II. Ook voor de in de Metalektro belangrijke beroepsklasse van Technische en industrieberoepen wordt een lichte krimp van -0.3\% voorspeld. Deze werkgelegenheidsontwikkeling steekt ongunstig af tegen de gemiddelde jaarlijkse stijging van de werkgelegenheid van $0.8 \%$ voor alle sectoren.

\section{Arbeidsmarktprognoses voor specifieke beroepen}

In deze alinea zullen wij de ontwikkeling presenteren van een aantal specifieke beroepen die van belang zijn voor de Metalektro. Deze ontwikkelingen zijn gebaseerd op de eerder genoemde prognoses van het ROA. Figuur 8.2 laat zien dat de verwachte uitbreidingsvraag voor de meeste technische functies negatief is. Voor alle technische beroepen wordt een werkgelegenheidskrimp verwacht, met uitzondering van de elektromonteurs, laders en lossers en de systeemanalisten. Deze krimp is het grootst voor de werktuigbouwkundig ontwerpers en hoofden technische dienst met $5.5 \%$ per jaar over een periode van vijf jaar, gevolgd door de metaalbewerkers met $3.5 \%$ per jaar. Bij de niet-technische functies wordt voor het administratief personeel en de technisch bedrijfskundig medewerkers een (licht) positieve uitbreidingsvraag voorspeld. Receptionisten, administratieve employés en de technischcommerciële medewerkers zullen daarentegen worden geconfronteerd met een krimpende werkgelegenheid.

De verwachte werkgelegenheidskrimp voor de technische beroepen is overigens groter dan eerder voor de jaren 2005-20IO werd voorspeld (zie de Arbeidsmarktmonitor Metalektro 2005).

Naast de vraag naar personeel als gevolg van werkgelegenheidsgroei is er ook sprake van een vervangingsbehoefte, die ontstaat doordat personeel vanwege pensioen of andere redenen de arbeidsmarkt verlaat. Bij de meeste technische functies is er sprake van een forse vervangingsvraag, omdat veel ouder personeel de komende jaren de arbeidsmarkt zal verlaten. Het grootste jaarlijkse vervangingsvraagpercentage wordt voorspeld voor laders en lossers (5.5\%), productiemedewerkers (3.9\%), en metaalbewerkers $(3.3 \%)$. Onder het niet-technisch personeel is de vervangingsvraag het hoogst voor de receptionisten en administratieve employés (4.I\%).

Bij een werkgelegenheidskrimp is het aantal baanopeningen in de praktijk gelijk aan de vervangingsvraag. Dit komt doordat op sectorniveau de werkgelegenheidskrimp doorgaans geen negatief effect heeft op de behoefte aan nieuw personeel op grond van de vervangingsvraag. 


\section{Figuur 8.3}

Uitbreidingsvraag, vervangingsvraag en totaal aantal baanopeningen per beroepsgroep, 2007-2012 (gemiddeld jaarlijks \% van de werkgelegenheid)

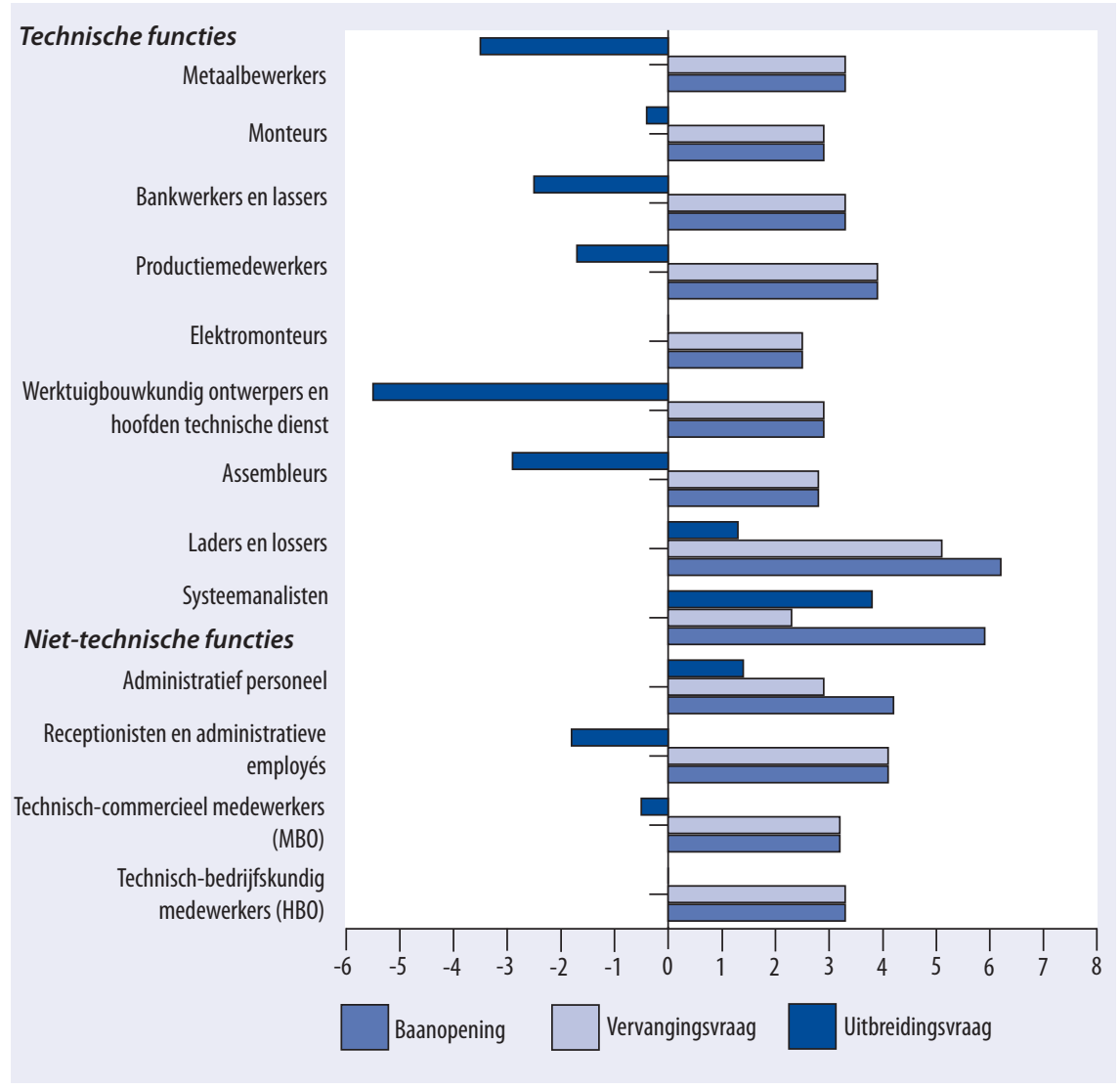

Bron: ROA (2007)

Ondanks de voorspelde krimpende werkgelegenheid in een aantal technische functies is er toch een behoorlijke vraag naar nieuwkomers. In veel technische functies wordt het aantal baanopeningen dan ook duidelijk gedomineerd door de vervangingsvraag. Opvallend hoge baanopeningen hebben de laders en lossers met 6.2\% per jaar. Dit komt door een combinatie van een zeer hoge vervangingsvraag en een positieve uitbreidingsvraag. Ook voor de systeemanalisten worden relatief veel baanopeningen voorspeld $(5.9 \%)$. Dit komt door een forse uitbreidingsvraag gecombineerd met een gemiddelde vervangingsvraag.

\section{Arbeidsmarktprognose voor specifieke opleidingen}

Als bedrijven functies invullen gaat het er vaak om mensen met een bepaalde opleidingsachtergrond aan te trekken. Daarom is het erg belangrijk om inzicht te hebben 
in de verwachte vraag- en aanbodontwikkelingen voor specifieke opleidingen. Hierbij zal slechts een aantal, voor de Metalektro belangrijke, opleidingen worden gepresenteerd.

Figuur 8.4 geeft een overzicht van de vervangingsvraag, uitbreidingsvraag en resulterende baanopeningen in de jaren 2007-20I2. Het gaat in deze prognoses niet alleen om de vraag vanuit de Metalektro, maar om de totale vraag naar mensen met deze opleidingsachtergrond. Uit figuur 8.4 blijkt dat de uitbreidingsvraag - die de totale ontwikkeling van de werkgelegenheid in een bepaalde opleiding weergeeft - slechts voor drie opleidingen negatief is: voor $H B O$ werktuigbouwkunde wordt met -I.6\% jaarlijks de grootste krimp voorspeld, gevolgd door $V M B O$ metal met -0.6\%. MBO werktuigbouw en mechanische techniek krimpt slechts licht met -0.1\%. De grootste positieve uitbreidingsvraag heeft $H B O$ elektrotechniek met een jaarlijkse groei van $2.2 \%$. Wanneer men de technische met de niet-technische opleidingen vergelijkt is duidelijk vast te stellen dat de niet-technische beroepen over het algemeen meer groeien.

De vervangingsvraag - ook weergegeven in figuur 8.4 - zal vooral voor de lagere opleidingen behoorlijk hoog zijn. Zo hebben onder de technische opleidingen de opleidingen $V M B O$ metal met $4.9 \%$, VMBO bouw met $5 \%$, en $M B O$ werktuigbouw en mechanische techniek met $4.9 \%$ zeer hoge jaarlijkse vervangingsvraagpercentages. De vervangingsvraag onder de hoger opgeleiden is iets lager. Daarbij is de vervangingsvraag voor $H B O$ elektrotechniek van 3.8\% een uitschieter naar boven. De verschillen in de vervangingsvraag naar opleidingsniveau zijn het gevolg van de varieteit in leeftijdsopbouw van de werkenden die deze opleidingen hebben afgerond. Doordat jongeren vaak een hogere opleiding hebben, is er vaak sprake van een hogere vervangingsvraag onder de lager opgeleiden.

Ook hier worden de baanopeningen voornamelijk gedomineerd door de vervangingsvraag. De combinatie van uitbreidings- en vervangingsvraag leidt voor een aantal technische opleidingen tot zeer hogere baanopeningspercentages: zo wordt voor $V M B O$ metaal jaarlijks $4.9 \%$, voor $V M B O$ bouw $5.4 \%$ en voor $H B O$ elektrotechniek maar liefst $5.7 \%$ van werkgelegenheid aan baanopeningen voorspeld. Onder de niettechnische beroepen is de $H B O$ bedriffskunde opleiding met $4.6 \%$ aan baanopeningen ook behoorlijk groot.

Om te bekijken in hoeverre de verwachte uitbreidings- en vervangingsvraag tot knelpunten in de personeelsvoorziening leiden, moet de verwachte vraag naar personeel met een bepaalde opleidingsachtergrond geconfronteerd worden met het verwachte arbeidsmarktaanbod. Figuur 8.5 geeft de verwachte instroom per opleiding weer. Per groep, technisch of niet-technische opleiding, is de instroom gerangschikt naar het verwachte knelpunt in de personeelsvoorziening. Hoe hoger het niveau van de opleiding hoe groter de verwachte knelpunten. 


\section{Figuur 8.4}

Uitbreidingsvraag, vervangingsvraag en totaal aantal baanopeningen per opleiding, 2007-2012 (gemiddeld jaarlijks \% van de totale werkgelegenheid)

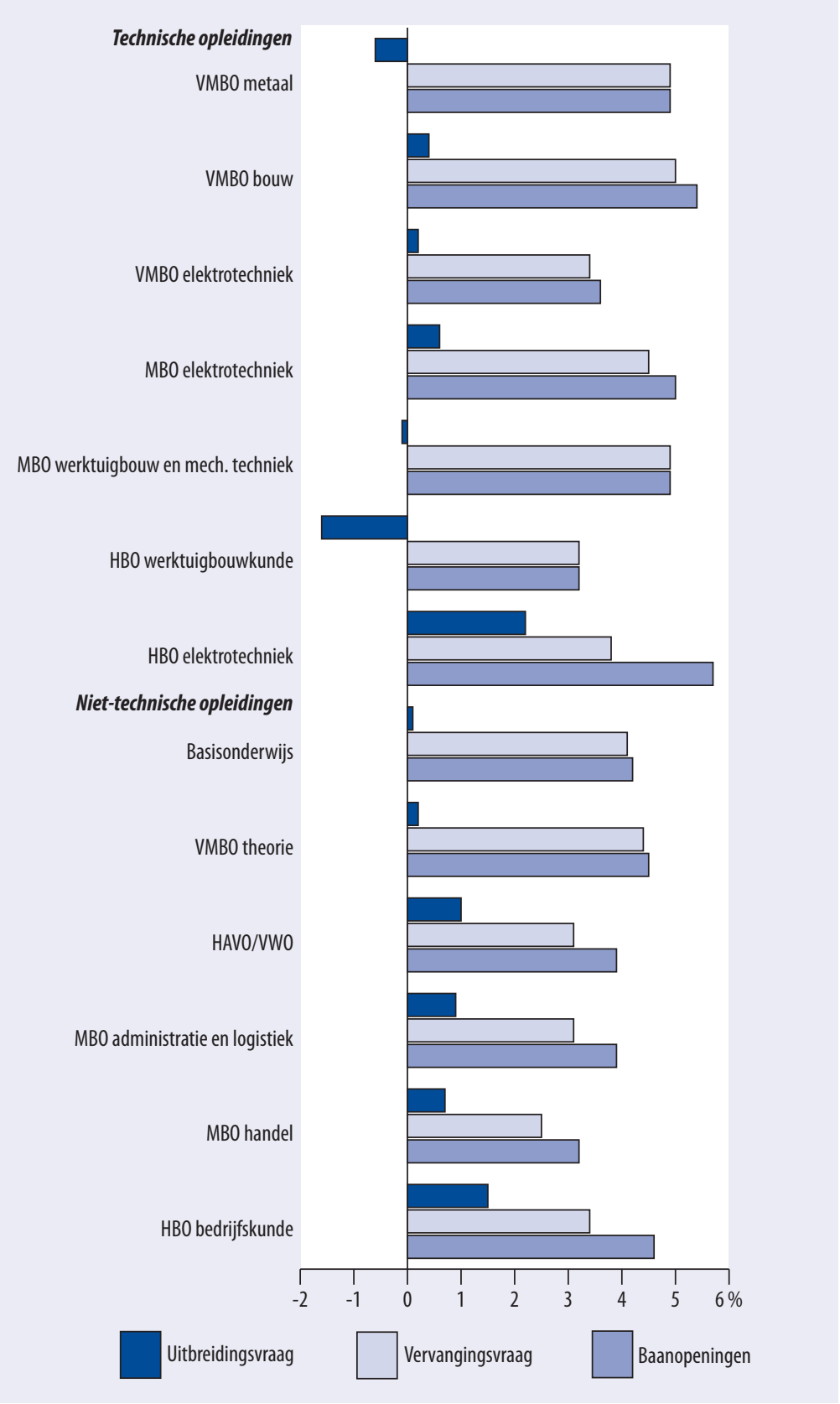

Bron: ROA 
Voor alle technische opleidingen worden grote knelpunten verwacht. Dit komt voornamelijk doordat bij deze opleidingen de instroom duidelijk lager is dan bij de niettechnische opleidingen. Bij de niet-technische opleidingen valt vooral $M B O$ handel op. Een enorme instroom van schoolverlaters, van jaarlijks meer dan $5 \%$ van de werkgelegenheid, zorgt voor een overschot aan schoolverlaters.

\section{Figuur 8.5}

Instroom per opleiding, 2007-2012 (gemiddeld jaarlijks \% van de werkgelegenheid)

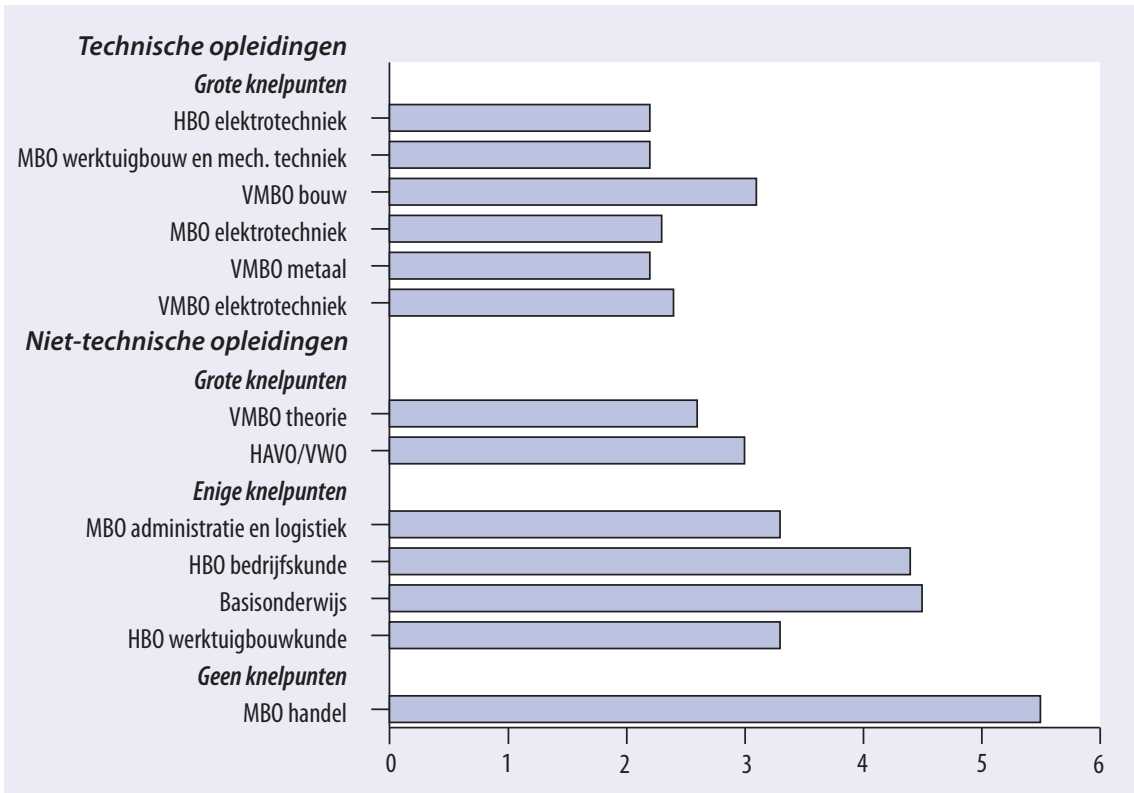

Bron: ROA

\subsection{Werven in de toekomst}

Wat betekenen de voorgaande prognoses nu voor de Metalektro? Figuur 8.6 laat zien dat de Metalektrobedrijven meer problemen verwachten dan het tekortschieten van het aanbod uit de opleidingen.

De gediplomeerde schoolverlaters beschikken volgens veel bedrijven ook in onvoldoende mate over de juiste competenties. Bedrijven moeten vaak de instromers uit het onderwijs nog vaktechnische, maar ook andere relevante competenties nog aanleren als zij instromen in het bedrijf. $54 \%$ van de bedrijven geeft aan dat zij op dit punt ook de komende vijf jaar nog problemen verwacht. 
Maar ook de markt voor ervaren technisch personeel is problematisch: $50 \%$ van de bedrijven verwacht dat ze de komende 5 jaar geconfronteerd zullen worden met een tekortschietend aanbod van sollicitanten met voldoende werkervaring.

Daarnaast is er een aantal afgeleide problemen. Te hoge salariseisen (31\%) of concurrentie van andere bedrijven uit de branche $(27 \%)$ worden hier vooral genoemd.

\section{Figuur 8.6}

Verwachte problemen bij het vinden van technisch personeel in de komende 5 jaar (\% bedrijven)

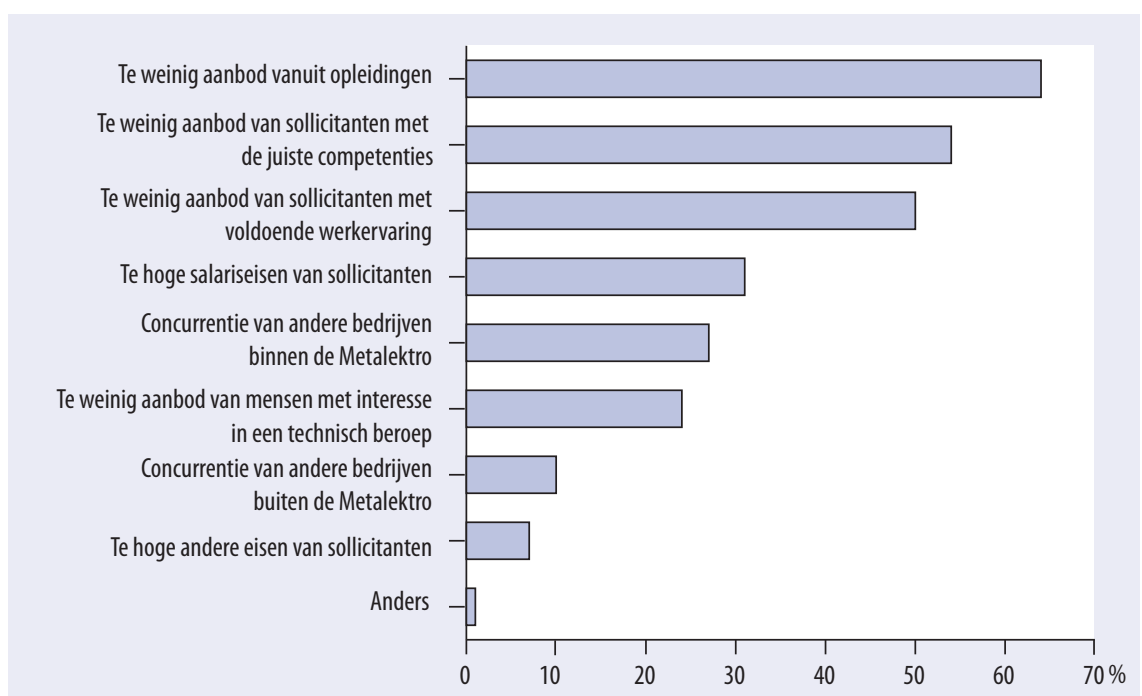

Bron: ROA / Werkgeverspanel Metalektro 2007

\subsection{Veranderingen in functies}

De toekomst brengt ook duidelijke veranderingen in de functies van het technisch personeel vanwege de in hoofdstuk 6 besproken procesinnovaties en organisatorische veranderingen.

In figuur 8.7 maken wij een onderscheid tussen veranderingen die in 2008 worden verwacht en veranderingen die de komende vijf jaar worden verwacht. Twee functieveranderingen springen daaruit naar voren. Het belang van de gedragsmatige competenties - zoals initiatief tonen, probleemoplossend vermogen - zal in 2008 toenemen, zo stelt $48 \%$ van de bedrijven. Een even grote groep bedrijven ziet het belang van klantgericht werken het komende jaar toenemen. Dit geldt ook voor de komende 5 jaar. Interessant zijn ook twee aan elkaar gerelateerde veranderingen die een vijfde tot een kwart van de bedrijven het komende jaar verwacht: werknemers op lager niveau krijgen meer verantwoordelijkheden, waarbij de functies ook breder worden, ofwel allround. Op de wat langere termijn wordt dit zelfs door bijna de helft van de bedrijven 
verwacht. Daarnaast zal de specialisatie op sommige gebieden en bij sommige functies toenemen. Terwijl slechts I $3 \%$ van de bedrijven dit voor het komende jaar verwacht, stelt $44 \%$ van de bedrijven dat dit binnen 5 jaar gebeurt.

\section{Figuur 8.7}

Verwachte veranderingen in functies van het technisch personeel (\% bedrijven)

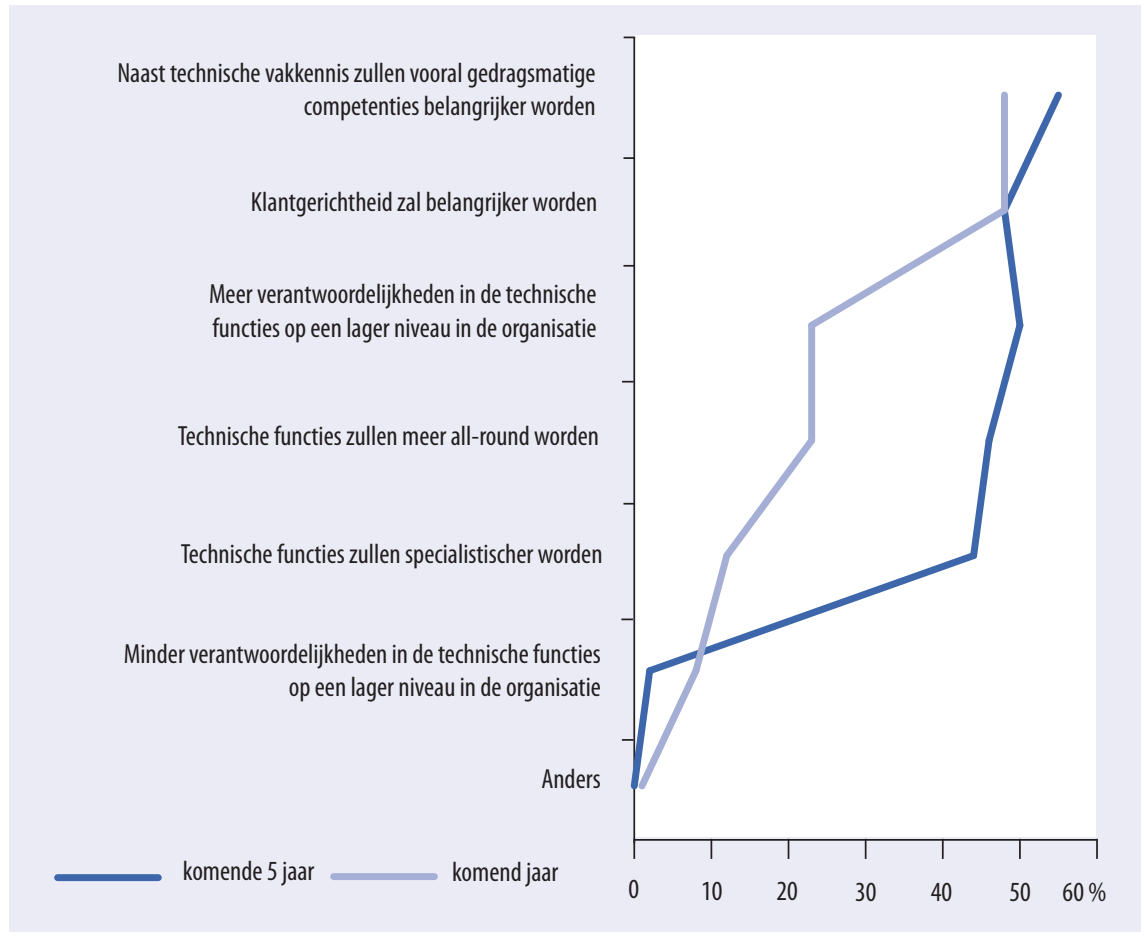

Bron: ROA / Werkgeverspanel Metalektro 2007

Interessant is ook om deze uitkomsten met het voorgaande jaar te vergelijken. Toen werd al door even veel bedrijven een toename verwacht in het belang van klantgerichtheid en van gedragsmatige POFI+-competenties.

Er zijn wel minder bedrijven die een snelle verandering naar meer verantwoordelijkheden in de technische functies en een verschuiving naar meer allround functies verwachten. In de voorgaande monitor gaf nog ruim 30\% aan dit binnen één jaar te verwachten, tegen $20 \%$ nu. De verwachting voor de termijn van 5 jaar blijft wel gelijk. Men beseft dat deze veranderingen eraan komen, maar waarschijnlijk niet zo snel als men vorig jaar nog dacht. 


\subsection{Speerpunten voor toekomstig HRM}

De speerpunten voor toekomstig HRM beleid hebben voor meer dan driekwart van de bedrijven betrekking op de inzetbaarheid van hun personeel (zie figuur 8.8). Een duidelijk speerpunt voor de toekomst is het verder stimuleren van de scholings- en cursusdeelname. Maar liefst 50\% van de bedrijven wil hier in de nabije toekomst nog meer aandacht aan schenken. Het stimuleren van scholing heeft een opmerkelijke ontwikkeling doorgemaakt in de rij van toekomstige speerpunten. Stond dit in 2005 slechts bij krap een derde van de bedrijven op de agenda, in 2006 was dit gestegen naar $38 \%$. Deze positieve trend heeft zich nu dus voortgezet.

\section{Figuur 8.8}

Speerpunten in het personeelsbeleid voor de komende 5 jaar (bedrijven)

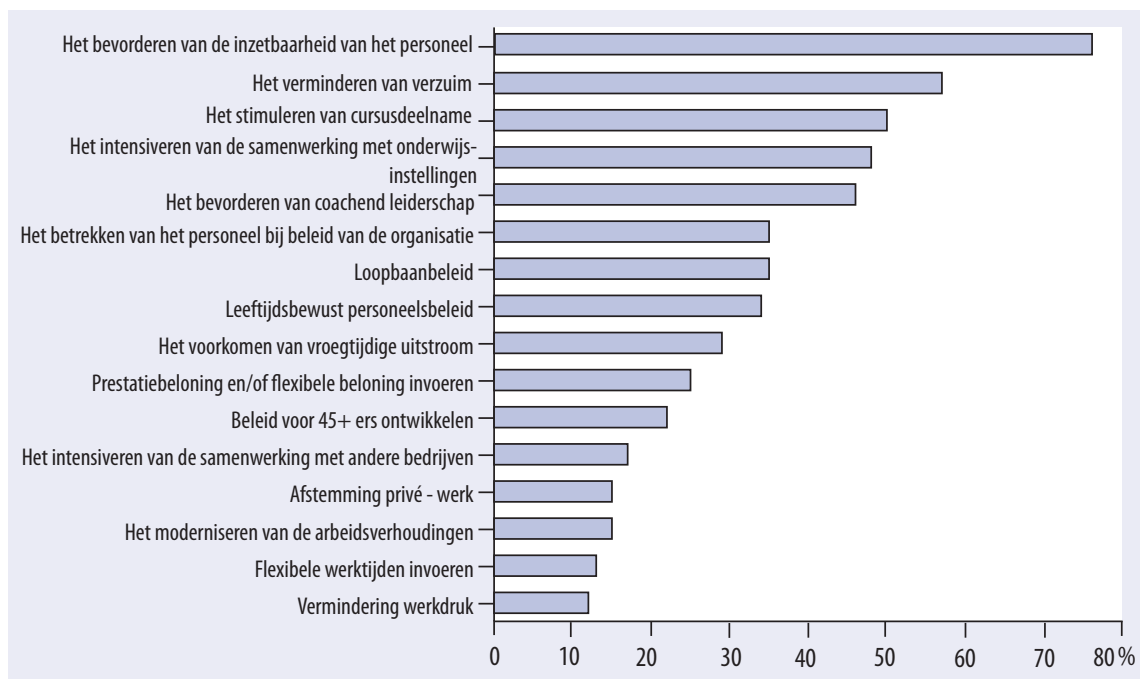

Bron: ROA/Werkgeverspanel Metalektro 2007

Een tweede trend die duidelijk zichtbaar is, is dat bedrijven meer samenwerking zoeken met onderwijsinstellingen. Bijna de helft van de bedrijven geeft aan dat dit een toekomstig speerpunt is van hun HRM beleid. Ook hier is een stijging te zien over de laatste drie jaar: van een kwart van de bedrijven in 2005, naar krap een derde van de bedrijven in 2006 , tot $48 \%$ van de bedrijven in 2007 . Bedrijven zien dat zij samenwerking met onderwijsinstellingen niet alleen nodig hebben om nieuw personeel vroegtijdig aan zich te binden, maar ook om ervoor te zorgen dat opleidingen de juiste competenties en vaardigheden aanleren. Daarentegen blijft samenwerking met andere bedrijven met I7\% op een lager niveau. Dit is vergelijkbaar met het in het voorgaande jaar ( $15 \%)$.

Nieuwe werkvormen en nieuwe organisatievormen zijn ook terug te vinden in de toekomstige HRM speerpunten. Zo staat het bevorderen van coachend leiderschap 
met $46 \%$ bij bijna de helft van de bedrijven op de agenda. $35 \%$ van de bedrijven wil het personeel meer betrekken bij de organisatie en slechts $15 \%$ wil de arbeidsverhoudingen moderniseren.

Het voorkomen van voortijdige personeelsuitstroom (zie hoofdstuk 2) staat bij $29 \%$ van de bedrijven op de agenda. Dit is vergelijkbaar met het voorgaande jaar. Zeker in tijden dat het moeilijk is om nieuw personeel te werven is dit een belangrijk element om het personeel op peil te houden. In dit kader past ook het beleid om oudere werknemers beter bij het bedrijf te betrekken en te behouden. Een derde van de bedrijven zegt een leeftijdsbewust personeelsbeleid te willen ontwikkelen, $29 \%$ wil vroegtijdige uitstroom voorkomen, en $22 \%$ wil speciaal beleid voor $45+$ 'ers ontwikkelen. Deze maatregelen voor het behoud van oudere medewerkers, zoals die ook in hoofdstuk 7 beschreven werden, liggen op een vergelijkbaar niveau als in het voorgaande jaar.

Een specifieke doelstelling is het vermijden van verzuim (57\%). Deze doelstelling lag vorig jaar bij de Metalektro bedrijven nog op een lager niveau (39\%), maar staat nu weer iets hoger op de agenda. Het niveau is weer terug op het hogere niveau zoals dit was in 2005 .

Ook zijn er HRM speerpunten die er op gericht zijn om in te gaan op de individuele werknemer en zijn voorkeuren. Daarbij scoort het hebben van een goed loopbaanbeleid het hoogst (35\% van de bedrijven). Door een goed loopbaanbeleid is het duidelijk voor de werknemer hoe en onder welke voorwaardes een verdere ontwikkeling mogelijk is. Maar ook de werkgever heeft hier baat bij omdat aankomende vacatures hierdoor vaker intern kunnen worden ingevuld. Een kwart van de bedrijven heeft de invoereing van prestatiebeloning voor de komende vijf jaar op de agenda staan. Prestatie- of flexibele beloning kan afhankelijk zijn van individuele, groeps-, of bedrijfprestaties. Andere speerpunten zijn het invoeren van flexibele werktijden (I3\%), een betere afstemming privé - werk ( $15 \%)$, en een vermindering van de werkdruk (I $2 \%)$.

Welke instrumenten worden nu al toegepast en welke zullen een speerpunt van het HRM beleid worden? Figuur 8.9 vat het huidige gebruik en de toekomstverwachting samen. De grijze lijn geeft het percentage bedrijven weer dat aangeeft het HRM instrument momenteel te gebruiken. De blauwe lijn geeft het percentage van de bedrijven weer dat verwacht dit in de toekomst intensiever te gaan inzetten als een van hun HRM speerpunten.

Zowel functioneringsgesprekken (88\%) en beoordelingsgesprekken met $(76 \%)$ worden al veelvuldig ingezet. Dit is een voortzetting van de toename van het gebruik van de afgelopen jaren. Ook bij opleidingsfaciliteiten $(74 \%)$ en het houden van geregeld werkoverleg $(89 \%)$ zet de stijgende trend zich voort. 


\section{Figuur 8.9}

Instrumenten van het huidige personeelsbeleid t.o.v. de instrumenten die in de toekomst versterkt toegepast worden (\% bedrijven)

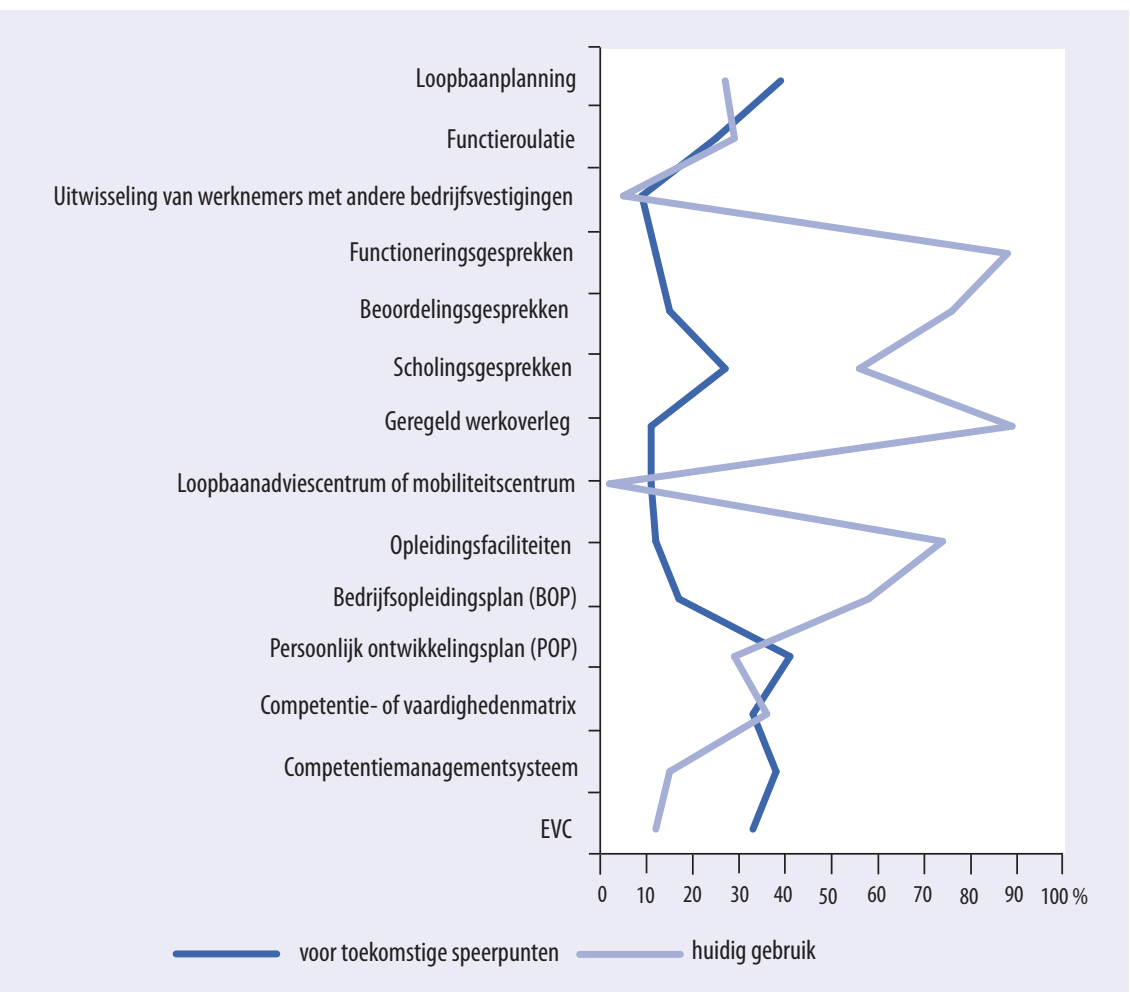

Bron: ROA/Werkgeverspanel Metalektro 2007

Loopbaanplanning - dat al door $27 \%$ van de bedrijven wordt toegepast - kan ook worden ondersteund door het opstellen van persoonlijke ontwikkelingsplannen (POP). Het huidige gebruik van $29 \%$ is weliswaar nog niet al te hoog, maar $4 \mathrm{I} \%$ van de bedrijven ziet dit voor de komende vijf jaar als een van de speerpunten van hun HRM beleid.

Meer dan de helft van de bedrijven heeft ook Bedrijfsopleidingsplannen (BOP). Slechts $17 \%$ van de bedrijven verwacht dit instrument in de toekomst nog meer in te zetten. Dit wijst erop dat er sprake is van een verschuiving naar een meer individuele aanpak via persoonlijke ontwikkelingsplannen.

Om kennis in kaart te brengen, te certificeren en actief te managen is er de competentie- en vaardigheden matrix, die door $36 \%$ van de bedrijven wordt gebruikt. Momenteel worden de EVC's nog slechts door I2\% van de bedrijven gebruikt, maar een derde van de bedrijven verwacht hier in toekomst meer gebruik van te maken. 
$38 \%$ van de bedrijven verwacht in de toekomst competentie managementsystemen in te gaan zetten, en $\mathrm{I} 5 \%$ van de bedrijven gebruikt deze nu al.

\section{Loopbaanbeleid in de MKB}

Veel bedrijven zijn bezig om trainingsbeleid en loopbaanbeleid een structurele vorm te geven: "Ik maak voor 2 jaar een POP", zo kan ik vooruitgang bijhouden, en er kunnen duidelijke afspraken gemaakt worden:"Het is belangrijk om te monitoren, om objectief vast te stellen." Anders ontstaan situaties die een HRM manager bij zijn aantreden mee maakte: "Competenties moet je bijhouden, anders gebeurt er niets. Eerder keek er niemand naar, er werd slechts mondeling afgesproken wat men ging doen, zonder afspraken na te leven, dat levert dan ook weinig resultaat op." De rol van de leidinggevende is ook cruciaal: "POP's houd ik samen met de leidinggevende". Er zijn leidinggevenden die leren het, of ze leren het niet. Een goede leidinggevende op de werkvloer is technisch goed zijn, en moet de juiste 'soft skills'"' hebben."

Werkgevers verwachten diverse knelpunten tegen te komen bij het bereiken van hun speerpunten. Figuur 8.IO vat de knelpunten samen die de bedrijven verwachten. $37 \%$ van de bedrijven geeft aan problemen te verwachten met personeel dat moeilijk om kan gaan met veranderingen. Vorig jaar gaf $43 \%$ van de bedrijven nog aan hier problemen mee te verwachten. $24 \%$ van de bedrijven geeft aan dat de flexibiliteit van het personeel tekort schiet. Dit is een duidelijke afname ten opzichte van 2006 toen nog $35 \%$ van de bedrijven dit aangaf. Wel is het aandeel bedrijven gestegen dat aangeeft een knelpunt te verwachten rond de motivatie van hun personeel: $20 \%$ van de bedrijven verwacht problemen vanwege ongemotiveerd personeel. Vorig jaar was dit nog maar bij $13 \%$ van de bedrijven het geval.

\section{Figuur 8.10}

Knelpunten bij het bereiken van de speerpunten (\% bedrijven)

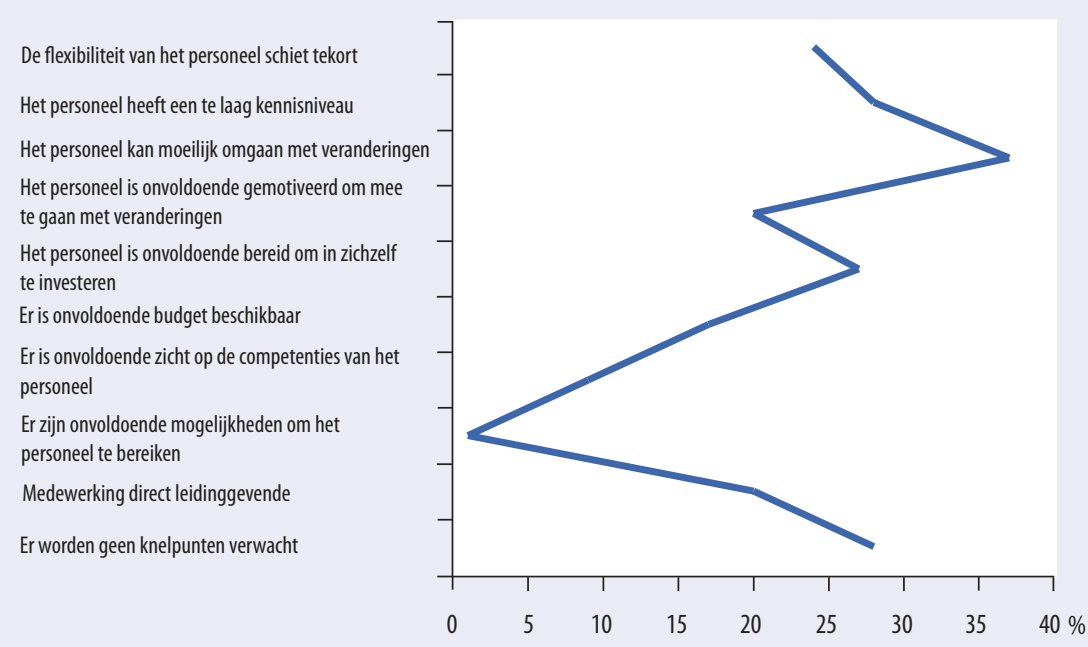

Bron: ROA/Werkgeverspanel Metalektro 2007 
Het tekortschieten van het kennisniveau van het personeel is voor $28 \%$ van de bedrijven een mogelijk knelpunt bij het bereiken van toekomstige speerpunten. Het gebrek aan kennis en vaardigheden kan worden opgevangen door scholing en training. Problematisch is in dit opzicht dat $27 \%$ van de bedrijven verwacht dat hun personeel onvoldoende bereid is in zichzelf te investeren. Dit is een duidelijke stijging ten opzichte van de $15 \%$ uit het voorgaande jaar. Een ander probleem waarvoor bedrijven moeten waken is dat direct leidinggevenden niet altijd meewerken aan het bereiken van de speerpunten. Een vijfde van de bedrijven denkt dat dit een knelpunt zal zijn.

Het aandeel bedrijven dat geen knelpunten verwacht blijft met $28 \%$ nagenoeg stabiel, het is een lichte stijging ten opzichte van de $26 \%$ van het voorgaande jaar. 


\section{Agenda voor de toekomst}

In dit hoofdstuk passeren de belangrijkste ontwikkelingen in de metalektrosector in vogelvlucht de revue en kijken we wat deze ontwikkelingen betekenen voor het beleid van de bedrijven. In paragraaf 9.I gaan we achtereenvolgens in op de huidige hoogconjunctuur, het ontwikkelen van een lange-termijn strategie ten aanzien van de personeelsbehoefte, de voortschrijdende upgrading van het gevradgde competentieniveau en de vraag naar "POFI" competenties, het opleidingsbeleid, het werven en zelf opleiden van nieuw personeel, het loopbaanbeleid en het levensfasebewuste personeelsbeleid van de bedrijven. In paragraaf 9.2 presenteren we een vernieuwde Agenda voor de Toekomst. Deze agenda biedt een zevental handreikingen die erop gericht zijn de effectiviteit van het arbeidsmarkten personeelsontwikkelingsbeleid van de metalektrobedrijven de komende jaren verder te vergroten.

\subsection{Ontwikkelingen en trends}

\section{Hoogconjunctuur biedt kansen}

In de huidige hoogconjunctuur is de personeelskrimp in de Metalektro tot stilstand gekomen. Door de hoge groei van de productie is er zelfs sprake van een lichte groei van de werkgelegenheid. De keerzijde hiervan is dat tekorten aan personeel door steeds meer bedrijven als een productiebelemmering wordt ervaren. In dit verband is het interessant om te zien dat veel Metalektrobedrijven hun personeelsgroei met name hebben gerealiseerd door het verminderen van de personeelsuitstroom. Dit is temeer opmerkelijk omdat het in een hoogconjunctuur voor werkenden gemakkelijker is om bij een ander bedrijf te gaan werken. Kennelijk zijn veel bedrijven er in geslaagd hun personeel beter te "boeien en binden". Dit is een goede ontwikkeling, die de Metalektrobedrijven verder moeten zien uit te bouwen door gebruik te maken van de mogelijkheden die de huidige hoogconjunctuur biedt om meer te investeren in de competenties en employability van het personeel en sociale innovaties door te voeren die de aantrekkelijkheid van het (blijven) werken in de Metalektro vergroten.

Lange-termijn strategie ten aanzien van de personeelsbehoefte

Veel Metalektro bedrijven geven aan dat het wenselijk zou zijn om een goede langetermijn strategie te hebben voor het invullen van hun personeelsbehoefte. De meeste 
bedrijven slagen er om verschillende redenen echter niet in om dit te realiseren. Sommigen geven aan dat hun bedrijf te klein is om een lange-termijn strategie rendabel te maken. Anderen zeggen dat hun personeelsverloop moeilijk te voorspellen is, of dat hun afzet hiervoor teveel fluctueert. De bedrijven die wel een lange-termijn strategie met betrekking tot de invulling van hun personeelsbehoefte hebben ontwikkeld proberen allereerst een goed beeld te krijgen van het te verwachten personeelsverloop in de komende jaren. Andere belangrijke elementen van deze lange-termijn strategie zijn het opleiden van het eigen personeel voor toekomstige vacatures en het versterken van de samenwerking met scholen om de toekomstige instroom van schoolverlaters te vergroten.

\section{Voortschrijdende upgrading en vraag naar POFI+ competenties}

De dynamiek van de metalektrosector zal de komende jaren onveranderd groot blijven. Het merendeel van de bedrijven zal ook de komende jaren weer tal van product- en procesinnovaties doorvoeren Deze technologische innovaties gaan vaak gepaard met organisatorische veranderingen, die de nieuwe producten of productieprocessen flankeren met vernieuwingen in de organisatie van het werk. Deze innovaties leiden in veel bedrijven tot een upgrading van vereiste competenties. Bovendien is het van groot belang dat het personeel breed inzetbaar is en naast de noodzakelijke vaktechnische competenties beschikt over de gedragsmatige competenties die in de vorige edities van de Arbeidsmarktmonitor Metalektro zijn benadrukt in de POFI+ agenda.

- Probleemoplossend vermogen;

- Omgaan met veranderingen;

- Omgaan met klanten;

- Flexibiliteit;

- Initiatief.

\section{Opleidingsbeleid}

De vereiste upgrading van het personeel en de toenemende vraag naar technici die beschikken over de gevraagde gedragsmatige competenties vergen aanzienlijke investeringen in trainingen en opleidingen voor het personeel. Het is dan ook niet verwonderlijk dat de stijgende lijn in de scholingsinvesteringen van de Metalektrobedrijven zich in 2007 heeft voortgezet. Daarbij is het opmerkelijk dat het trainingsbeleid van de bedrijven selectiever is geworden in de zin dat er minder medewerkers een training hebben gevolgd, maar de investeringen voor de medewerkers die een opleiding hebben gevolgd sterk zijn toegenomen. Bij de meeste bedrijven ligt het accent in het scholingsbeleid nog steeds op de vaktechnische cursussen. Dit illustreert het grote belang dat veel bedrijven hechten aan het up-to-date houden van de competenties van hun technisch personeel. Meer dan de helft van de bedrijven geeft echter aan dat ze de komende jaren de trainingen en scholing meer willen richten op het verbeteren van het probleemoplossend vermogen van hun personeel, terwijl een op de vijf bedrijven 
aangeeft dat ze meer aandacht willen gaan schenken aan cursussen die gericht zijn op het omgaan met veranderingen. Dit illustreert dat de Metalektrobedrijven actiever invulling gaan geven aan de POFI+agenda.

Daarentegen blijken de Metalektrobedrijven nog niet meer aandacht te hebben voor het versterken van het informele leren op de werkplek, al geeft meer dan de helft van de bedrijven aan dat ze hun personeel door "on-th-job" training op veranderingen voorbereidt. Wel stimuleert ruim een derde van de bedrijven het coachend leidinggeven, terwijl ruim $20 \%$ van de bedrijven aandacht heeft voor het creëren van een leerrijke werkomgeving. Uit onderzoek blijkt dat het informele leren van zeer groot belang is voor de competentieontwikkeling van werkenden. Het lijkt ook bij uitstek de weg te zijn waarlangs medewerkers hun POFI competenties kunnen verbeteren. Wat dit betreft is het verheugend dat bijna de helft van de bedrijven aangeeft dat het bevorderen van coachend leiderschap een speerpunt vormt in het personeelsbeleid voor de komende jaren.

\section{Werven en zelf opleiden van nieuw personeel}

Door de vergrijzing van het personeel en het veel te geringe aanbod van schoolverlaters neemt de krapte op de arbeidsmarkt toe. Daardoor moeten de metalektrobedrijven steeds vaker met andere bedrijven binnen en buiten de Metalektro concurreren om geschikt personeel te kunnen aantrekken. Ruim 40\% van de bedrijven verwacht ook dat ze de komende jaren problemen zullen ondervinden bij de vervanging van uitvoerend technisch personeel.

Een derde van de bedrijven probeert deze vervangingsproblemen te verminderen door de inzet van arbeidsbesparende technologie. Het overgrote deel van de bedrijven kan er echter niet onderuit om het wervingsbeleid te intensiveren. Daarbij worden veelal uitzendbureaus of andere commerciële werving- en selectiebureaus ingeschakeld. Een derde van de bedrijven is er ook toe overgegaan om scholieren actiever te benaderen. Het op peil houden van de instroom van nieuw personeel vereist echter ook dat bedrijven meer gaan investeren in hun relaties met het onderwijsveld. Bijna de helft van de bedrijven probeert overigens al technisch personeel te werven via de onderwijsinstellingen waarmee ze samenwerken. Daarbij gaat het echter in hoofdzaak om traditionele vormen van samenwerking, zoals het aanbieden van stageplaatsen. In aanvulling daarop zal er meer aandacht moeten komen voor meer innovatieve vormen van samenwerking.

Het overgrote deel van de bedrijven neemt nieuw personeel aan dat nog niet de vereiste competenties heeft, om ze vervolgens zelf op te leiden. Naast de arbeidsleerplaatsen in het kader van de BBL die veel bedrijven aanbieden, zien we momenteel ook dat enkele grote bedrijven hun eigen bedrijfsscholen weer optuigen of verder uitbreiden. Vanzelfsprekend vereist dit een goede lange-termijn strategie ten aanzien 
van de toekomstige personeelsbehoefte. Voor het bedrijf heeft zelf opleiden echter het grote voordeel dat het kan putten uit het veel grotere aanbod van lager opgeleiden.

De metalektrobedrijven zullen ook stappen moeten ondernemen om ervoor te zorgen dat het imago van het werk bij de metalektrobedrijven wordt verbeterd. Momenteel zien nog te veel schoolverlaters de Metalektro als een sector waarin het werk zwaar en lichamelijk belastend is. Om de wervingskracht van Metalektrobedrijven te vergroten zullen bedrijven er naar moeten streven om "employer of choice" te worden. In de huidige "war for talent" zullen bedrijven dit alleen kunnen realiseren als ze jongeren goede ontwikkelingsmogelijkheden en een aantrekkelijk loopbaanperspectief weten te bieden. Dit is immers precies het punt waarop de keuze voor techniek momenteel de concurrentieslag met de economisch-administratieve en commerciële functies verliest.

\section{Loopbaanbeleid}

Het bieden van goede ontwikkelingsmogelijkheden en een aantrekkelijk loopbaanperspectief aan schoolverlaters is natuurlijk niet alleen van belang voor het vergroten van de wervingskracht van de metalektrobedrijven. Door duidelijke loopbaanperspectieven te bieden zullen de bedrijven er ook beter in slagen om het personeel dat ze aantrekken te "boeien en binden", waardoor ongewenst personeelsverloop wordt voorkomen. Het bevorderen van verschillende vormen van interne mobiliteit bevordert ook een optimale ontwikkeling van de competenties en werkervaring van het personeel. Een goed loopbaanbeleid vergroot bovendien de motivatie van het personeel. Een goed loopbaanbeleid creëert voor het bedrijf zelf ook mogelijkheden om de inzetbaarheid van hun personeel te vergroten en daardoor flexibeler in te kunnen spelen op verschuivingen in de vraag op de afzetmarkt. Bovendien kan het een belangrijke bijdrage leveren aan de innovatiedynamiek. In het kader van het loopbaanbeleid is het ook wenselijk dat bedrijven medewerkers functies aanbieden waarin zij verschillende aan elkaar gerelateerde taken vanuit een eigen verantwoordelijkheid uitvoeren. Dit maakt het werk voor goede werknemers boeiender en vergroot de motivatie voor het werk. De nieuwe vormen van teamgericht werken die veel metalektrobedrijven doorvoeren bieden goede mogelijkheden om deze bredere functies te creëren.

Een goed loopbaanbeleid vereist ook een goede uitvoering en loopbaanmanagement. Hierdoor kan een werknemer doorgroeien qua competenties en verantwoordelijkheden. Ook biedt het de mogelijkheid om jonge medewerkers die kampen met aansluitingsproblemen tussen de door hen gevolgde opleiding en de eisen die hun functie stelt een goed ontwikkelingspad te bieden. Vanzelfsprekend is een goed loopbaanmanagement ook nauw verbonden met het opleidingsbeleid van het bedrijf. In dat geval is er sprake van een personeelsontwikkelingsbeleid. Daarbij zal er in functioneringsgesprekken veel aandacht moeten zijn voor de ontwikkelingsperspectieven van individuele medewerkers en de mogelijkheden om belemmerende competentietekorten te overbruggen door het volgen van trainingen of het leren op de werkplek. 
In aanvulling op een dergelijk persoonlijk opleidingsplan (POP) zullen bedrijven het informele leren van hun personeel moeten versterken door het bevorderen van coachend leiderschap.

\section{Leeftijdsfasebewust personeelsbeleid zet niet door}

Met het krapper worden van de arbeidsmarkt voor technisch opgeleiden wordt het voor de Metalektro steeds belangrijker om de vroegtijdige pensioenuitstroom van het oudere personeel zoveel mogelijk te beperken. Dit maakt het belangrijk om voldoende aandacht te hebben voor het op peil houden van de inzetbaarheid van oudere medewerkers. Het aantal bedrijven dat aangeeft dat een leeftijdsbewust personeelsbeleid de komende jaren een speerpunt vormt in het personeelsbeleid is echter vrijwel niet toegenomen. Tweederde van de bedrijven lijkt hier onvoldoende aandacht voor te hebben. Daar staat echter wel tegenover dat veel bedrijven wel degelijk specifieke maatregelen treffen die de vroegtijdige arbeidsmarktuitstroom van ouder personeel beperken. Zo probeert meer dan de helft van de bedrijven de inzet van oudere medewerkers te optimaliseren door hen in te zetten voor de kennisoverdracht naar jonge medewerkers. Ook meer in het algemeen krijgen oudere medewerkers vaak andere taken en verantwoordelijkheden. Ten slotte bieden steeds meer bedrijven de mogelijkheid tot deeltijdpensioen, om daarmee het vroegtijdige vertrek van ouder personeel dat nog goed inzetbaar is te beperken.

Leeftijdsfasebewust personeelsbeleid moet echter niet beperkt blijven tot aandacht voor oudere werknemers. Om de kennis en vaardigheden van het personeel op een optimale wijze te kunnen benutten is het van belang dat bedrijven ook voldoende aandacht blijven houden voor hun personeel dat nog niet vergrijsd is. Door er nu al voor te zorgen dat ook de wat jongere werknemers hun competenties en ervaring op de juiste wijze kunnen ontwikkelen en goede loopbaanperspectieven te bieden, kunnen bedrijven ervoor zorgen dat deze mensen, wanneer ze wat ouder zijn, van grote waarde blijven voor het bedrijf.

\section{Sociale innovaties}

Het overgrote deel van de Metalektrobedrijven geeft aan dat ze organisatieveranderingen hebben doorgevoerd die ze typeren als sociale innovaties. Ook voor de komende jaren zal er veel aandacht zijn voor deze sociale innovaties. Daarbij denken veel bedrijven vooral aan het variabel inzetten van het personeel, en andere vormen van teamgericht werken. Ook verwacht een deel van de bedrijven (verder) te gaan schrappen in het aantal managementlagen en taken die in verschillende afdelingen worden verricht te integreren. Deze innovaties zijn primair bedoeld om de arbeidsproductiviteit te verhogen en een kwaliteitsverbetering van de producten te realiseren. Veel bedrijven beseffen echter ook dat ze op deze manier kwalitatief hoogwaardige werkgelegenheid kunnen bieden die de aantrekkingskracht die het bedrijf heeft op de arbeidsmarkt zal vergroten. 


\section{Verspreiding good practices en HR tools}

Kleinere en middelgrote bedrijven blijken vaak onvoldoende mogelijkheden te hebben om hun personeelsontwikkelings- en arbeidsmarktbeleid op eigen kracht verder te ontwikkelen. Regionale samenwerking met andere bedrijven kan er toe bijdragen dat deze bedrijven mogelijkheden kunnen creëren om de knelpunten waarmee ze geconfronteerd worden te overwinnen. Dit is zeker het geval wanneer kleinere bedrijven onvoldoende informatie hebben over de mogelijkheden tot en de voor- en nadelen van verschillende sociale innovaties. Daarbij gaat het ook om de overdracht van "good practices". Het gaat hierbij vooral om het identificeren van initiatieven op het vlak van arbeidsmarkt- en personeelsbeleid die bij andere bedrijven effectief blijken te zijn.

De overdracht van good practices kan er ook toe bijdragen dat niet ieder bedrijf zelf op zoek hoeft te gaan naar de wijze waarop bepaalde sociale innovaties ontwikkeld en geïmplementeerd kunnen worden. Daarbij is het van groot belang dat de inzichten die verkregen zijn uit de good practices vertaald worden in een aantal toegankelijke, gemakkelijk hanteerbare, en direct implementeerbare tools. Met behulp van deze concrete HR-tools kunnen veel bedrijven in de Metalektro de effectiviteit van hun arbeidsmarkt- en personeelsontwikkelingsbeleid vergroten.

\subsection{Agenda voor de Toekomst}

Wat betekenen de ontwikkelingen in de Metalektro voor het beleid dat de bedrijven de komende jaren moeten gaan voeren? We vatten de belangrijkste punten samen in de Agenda voor de Toekomst:

Bedrijven zullen moeten proberen om hun HR beleid in te bedden in een langetermijn strategie voor het invullen van hun personeelsbehoefte. Startpunt van deze strategie is het zo goed mogelijk in kaart brengen van de verwachte personeelsbehoefte in de komende jaren. In aanvulling daarop zal vanuit deze lange-termijn strategie moeten worden bezien in hoeverre de hieronder genoemde actiepunten binnen het bedrijf meer of minder accent moeten krijgen.

\section{Opleidings- en ontwikkelingsbeleid}

Naast het investeren in vaktechnische vaardigheden, moeten de inspanningen om de upgradingsdoelstellingen te realiseren, gericht worden op vijf essentiële gedragsmatige competenties, die we kunnen aanduiden als de POFI+ agenda:

- Probleemoplossend vermogen;

- Omgaan met veranderingen;

- Omgaan met klanten;

- Flexibiliteit;

- Initiatief. 
Metalektro bedrijven zullen in hun opleidings- en ontwikkelingsbeleid meer aandacht moeten gaan schenken aan het versterken van de POFI competenties van hun technisch personeel. Daarbij dient er met name meer aandacht te komen voor het versterken van het informele leren op de werkvloer.

\section{Wervingsbeleid}

Vanwege de toenemende vergrijzing en de afnemende instroom van schoolverlaters zullen bedrijven hun wervingskracht moeten vergroten. Dit beleid moet zich richten op:

- Het bieden van een aantrekkelijk loopbaanperspectief aan nieuwe medewerkers;

- Het verder ontwikkelen van innovatieve manieren van samenwerking met het onderwijsveld;

- Het verbeteren van het imago van de metalektrosector;

- Het zelf opleiden van nieuwe medewerkers.

\section{Loopbaanbeleid}

Het HRM moet zich meer gaan richten op het stimuleren van verschillende vormen van interne mobiliteit, niet alleen vanwege de innovatiedynamiek en de behoefte aan flexibiliteit, maar ook om het personeel aantrekkelijke loopbanen te kunnen bieden en ongewenst verloop te voorkomen. Door het creëren van functies waarin werknemers verschillende aan elkaar gerelateerde taken vanuit een eigen verantwoordelijkheid uitvoeren ontstaat hoogwaardige werkgelegenheid die werknemers boeit en bindt en de aantrekkingskracht van de sector op de arbeidsmarkt vergroot.

\section{Levensfasebewust personeelsbeleid}

De verdere ontwikkeling van levensfasebewust personeelsbeleid dat gericht is op vier cruciale elementen:

- Een pro-actief levensfasebewust personeelsbeleid voor alle werknemers;

- Investeren in de competentieontwikkeling van het oudere personeel door scholing, functieroulatie en informeel leren;

- Zorgen dat oudere werknemers zo lang mogelijk productief aan de slag kunnen blijven door middel van een gericht Active Aging beleid;

- Het stimuleren van mobiliteit in de laatste loopbaanfase en het ontwikkelen van flexibele uittredemogelijkheden die aansluiten bij de behoeften van het bedrijf en de medewerkers.

\section{Sociale innovaties}

Veel van de bovenstaande agendapunten vereisen dat bedrijven op verschillende terreinen sociale innovaties weten te realiseren gericht op het aantrekken en ontwikkelen van optimaal inzetbaar personeel. Dit vereist het vergroten van de innovativiteit van het HRM beleid binnen de grenzen van de mogelijkheden die het bedrijf hiervoor heeft. Om dit te kunnen realiseren moeten bedrijven, op soortgelijke wijze als 
ze dat doen bij technologische innovaties, meer aandacht geven aan de Research \& Development $(\mathrm{R} \& \mathrm{D})$ met betrekking tot sociale innovaties.

\section{Verspreiding van good practices en HR tools}

Kleinere en middelgrote bedrijven moeten de effectiviteit van het arbeidsmarkt- en personeelsontwikkelingsbeleid vergroten door samenwerking en kennisdeling op regionaal niveau en het verspreiden van good practices en bruikbare HR tools. 